\title{
DESENVOLVIMENTO DO RACIOCÍNIO LÓGICO MATEMÁTICO COM O USO DE TECNOLOGIAS DE INFORMAÇÃO E COMUNICAÇÃO PARA O ENSINO FUNDAMENTAL
}

Everson Muniz Guimarães

Juiz de Fora (MG)

Maio, 2021 


\author{
UNIVERSIDADE FEDERAL DE JUIZ DE FORA \\ INSTITUTO DE CIÊNCIAS EXATAS \\ Pós-Graduação em Educação Matemática \\ Mestrado Profissional em Educação Matemática
}

Everson Muniz Guimarães

\title{
DESENVOLVIMENTO DO RACIOCÍNIO LÓGICO MATEMÁTICO COM O USO DE TECNOLOGIAS DE INFORMAÇÃO E COMUNICAÇÃO PARA O ENSINO FUNDAMENTAL
}

Orientadora: Prof. a Dra Liamara Scortegagna

Dissertação de Mestrado apresentada ao Programa de Mestrado Profissional em Educação Matemática, como parte dos requisitos para obtenção do título de Mestre em Educação Matemática

Juiz de Fora (MG

Maio, 2021 
Guimarães, Everson Muniz .

Desenvolvimento do raciocínio lógico matemático com o uso de tecnologias de informação e comunicação para o ensino fundamental / Everson Muniz Guimarães. - 2021.

$90 \mathrm{f}$.

Orientadora: Liamara Scortegagna

Dissertação (mestrado acadêmico) - Universidade Federal de Juiz de Fora, Instituto de Ciências Exatas. Programa de Pós-Graduação em Educação Matemática, 2021.

1. Raciocínio Lógico Matemático. Tecnologias de Informação e Comunicação. Ensino de Matemática. I. Scortegagna, Liamara , orient. II. Título. 
"Desenvolvimento do Raciocinio Lógico Matemático com o uso de Tecnologias de Informaçăo e Comunicação para o Ensino Fundamental"

Dissertação apresentada ao Programa de Pós-Graduaçảo em Educação Matemítica da Universidade Federal de Juiz de Fora como requisito parcial à obtenção do título de Mestre em Educaçăo Matemática. Área de concentraçio: Educą̧ão Matemática.

Aprovadi em 27 de maio de 2021

BANCA EXAMINADORA
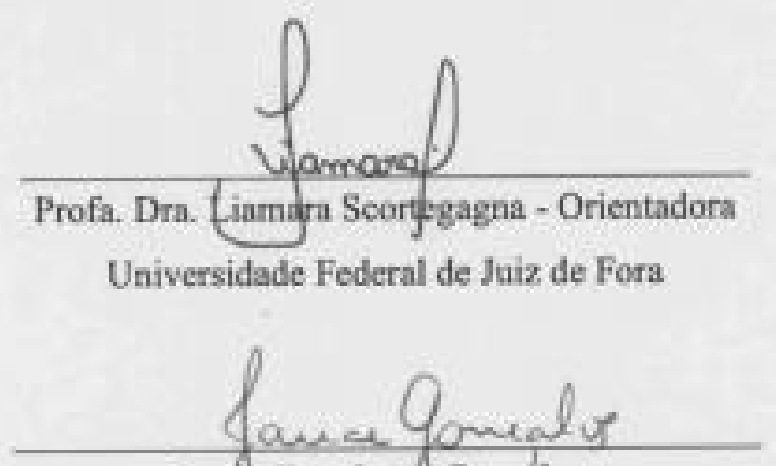

Profa Dra. Janad Gonçallves

Universidade Federal Rural da Amazônia

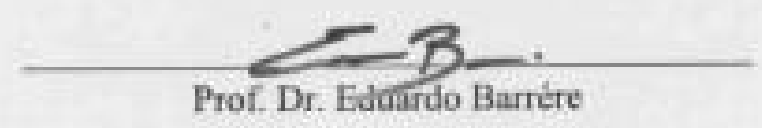

Universidade Federal de Juiz de Fora 


\section{RESUMO}

Esta pesquisa, desenvolvida na área de Educação Matemática, investiga alternativas para os docentes trabalharem o ensino e a aprendizagem do Raciocínio Lógico Matemático por meio das Tecnologias de Informação e Comunicação (TIC). O objetivo geral proposto foi desenvolver tarefas envolvendo a multiplicação do Conjunto dos Números Naturais para os educandos do Ensino Fundamental II que estimulem o desenvolvimento do Raciocínio Lógico Matemático com a utilização de tecnologias. E, como objetivos específicos, a pesquisa priorizou despertar interesse dos educandos e explorar as potencialidades dos conteúdos matemáticos a partir do uso de recursos digitais. Para demonstrar as potencialidades que as tecnologias proporcionam no processo de ensino e aprendizagem do Raciocínio Lógico Matemático e a produção de significados ocorrida, desenvolveu-se, aplicou-se e analisou-se uma sequência de tarefas utilizando o aplicativo WhatsApp como instrumento de mediação, interação e acompanhamento dos educandos do $8^{\circ}$ ano, bem como as devolutivas dos materiais impressos enviados pelos mesmos. Foi realizada a análise dos resultados da aprendizagem através de uma abordagem qualitativa, utilizando o Modelos dos Campos Semânticos proposto por Rómulo Lins e demonstradas as produções de significados geradas pelos educandos. Constatouse resultados positivos quando das interações dos educandos no grupo de WhatsApp, a partir das colaborações nas explicações de diferentes formas de resoluções das questões, possibilitando o entendimento e desenvolvimento por parte dos demais colegas e gerando a produção de significados. Foi possível perceber ainda contribuições e interações que, normalmente, não ocorrem em sala de aula, como por exemplo, a ajuda dos educandos de forma colaborativa nas explicações e sugestões para realização das atividades. Ainda, mediante ao cenário da Pandemia da Covid19, não foi possível executar a proposta inicial da pesquisa, a qual se referia apenas na presencialidade e o uso de laboratório de informática na escola. Assim, percebeuse a necessidade de adaptação para o Ensino Remoto Emergencial e, desta forma, resultou em dois Produtos Educacionais. $O$ primeiro se constitui na sequência de tarefas aplicadas com apoio do WhatsApp e o segundo a implementação da sequência no software Hot Potatoes, a qual poderá ser utilizada pelos docentes quando houver retorno às aulas presenciais. Como resultados da pesquisa, proporcionou-se aos docentes uma possibilidade de ensino de matemática instigante e motivador com uso de recursos tecnológicos, a fim de auxiliar os educandos a desenvolverem a capacidade do exercício da reflexão mental referente a situaçõesproblemas.

Palavras-chave: Raciocínio Lógico Matemático. Tecnologias de Informação e Comunicação. Ensino de Matemática. Whatsapp. Hot Potatoes. 


\begin{abstract}
This research, developed in the area of Mathematical Education, investigates alternatives for teachers to work teaching and learning Mathematical Logical Reasoning through Information and Communication Technologies (ICT). The proposed general objective was to develop tasks involving the multiplication of Natural Numbers sets for Elementary School Students II that stimulate the development of Mathematical Logical Reasoning with the use of ICT. Furthermore, as specific objectives, the research prioritized to awaken interest of students and explore the potential of mathematical content with the usage of digital resources. In order to demonstrate the potential that technologies provide in the teaching and learning process of Mathematical Logical Reasoning and the production of meanings that have occurred, a sequence of tasks has been developed, applied and assessed through the WhatsApp application as intercession, interaction and monitoring of the 8th grade students, as well as the return of the printed materials sent by them. The assessment of the learning results was carried out through a qualitative approach, using the Models of the Semantic Fields proposed by Rómulo Lins and demonstrated the productions of meanings generated by the students. Positive results were found in the interactions of the students on the WhatsApp group, based on collaborations in the different-way explanations of resolving the issues, enabling the understanding and development by the other students and generating the production of meanings. It was also possible to note contributions and interactions that normally do not occur in the classroom, such as, the help of students in a collaborative way in the explanations and suggestions for carrying out the activities. Still, due to the Pandemic of COVID-19 scenario, it was not possible to perform the initial research proposal, which would only occur presential and with the use of a computer lab at school. Thus, there was the need for adaptation for Emergency Remote Education and, thereby, resulted in two Educational Products. The first is the sequence of tasks applied with Whatsapp support and the second is the implementation of the sequence in the Hot Potatoes software, which can be used by teachers when there is a return to face-to-face classes. Because of the research, teachers were offered an exciting and motivating mathematics teaching possibility with the use of technological resources in order to help students to develop the ability to develop mental reflection regarding problem situations.
\end{abstract}

Keywords: Mathematical Logical Reasoning. Information and Communication Technologies. Mathematics Teaching. Whatsapp. Hot Potatoes. 


\section{LISTA DE QUADROS}

QUADRO 1 - MÉDIA POR EDIÇÃO DOS PAÍSES SELECIONADOS, MATEMÁTICA - PISA 2018

QUADRO 2 - RENDIMENTOS NA PROVA BRASIL DO MUNICÍPIO

QUADRO 3 - RENDIMENTOS NA PROVA BRASIL DA ESCOLA 1

QUADRO 4 - RENDIMENTOS NA PROVA BRASIL DA ESCOLA 2

QUADRO 5 - RENDIMENTOS NA PROVA BRASIL DA ESCOLA 3

QUADRO 6 - SELEÇÃO DE PESQUISAS UTILIZADAS NA REVISÃO DE LITERATURA

QUADRO 7 - CONTRIBUIÇÕES DOS TRABALHOS SELECIONADOS QUADRO 8 - RESULTADOS DAS TAREFAS 


\section{LISTA DE ABREVIATURAS E SIGLAS}

$\begin{array}{ll}\text { BBC } & \text { Britist Broadcasting Corporation } \\ \text { BNCC } & \text { Base Nacional Comum Curricular } \\ \text { CEMA } & \text { Colóquio de Educação Matemática } \\ \text { EMEM } & \text { Encontro Mineiro de Educação Matemática } \\ \text { ENEM } & \text { Encontro Nacional de Educação Matemática } \\ \text { EBRAPEM } & \text { Encontro Brasileiro de Estudantes de Pós-Graduação em Educação } \\ & \text { Matemática } \\ \text { IDEB } & \text { Índice de Desenvolvimento da Educação Básica } \\ \text { MCS } & \text { Modelo dos Campos Semânticos } \\ \text { OBR } & \text { Olimpíadas Brasileiras de Robótica } \\ \text { OBRI } & \text { Olimpíadas Brasileiras de Informática } \\ \text { PCN } & \text { Parâmetros Curriculares Nacionais } \\ \text { PISA } & \text { Programa Internacional de Avaliação de Estudantes } \\ \text { PPP } & \text { Projeto Político Pedagógico } \\ \text { SEED } & \text { Secretaria de Educação a Distância } \\ \text { TIC } & \text { Tecnologia de Informação e Comunicação } \\ \text { UFJF } & \text { Universidade Federal de Juiz de Fora }\end{array}$




\section{SUMÁRIO}

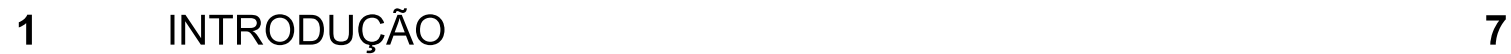

2 FUNDAMENTAÇÃO TEÓRICA

2.1 Tecnologias da Informação e Comunicação (TIC) no Ensino da Matemática $\quad 11$

2.2 Raciocínio Lógico Matemático 20

2.2.1 Tecnologias para o Pensamento Lógico Matemático 24

2.3 Modelos dos Campos Semânticos 31

3 REVISÃO DE LITERATURA $\quad \mathbf{3 4}$

3.1 Planejamento e execução da revisão de literatura 34

3.2 Objetivo da revisao de literatura 35

3.3 Base de dados $\quad 35$

3.4 Critérios de seleção e exclusão 35

3.5 Descrição dos Trabalhos Selecionados 37

4 METODOLOGIA $\quad 49$

4.1 Classificação da Pesquisa 49

4.2 Objetivos e procedimentos 51

4.3 Características da pesquisa 51

4.3.1 Local da pesquisa 51

4.3.2 Público alvo 52

4.4 Desenvolvimento e execução das tarefas 52

4.5 Coleta de dados $\quad 54$

4.6 Análise dos dados $\quad 54$

4.7 Escolha do software $\quad 55$

5 PROPOSTA DAS TAREFAS

6 APRESENTAÇÃO E ANÁLISE DOS DADOS 64

6.1 Descrição dos resultados das tarefas aplicadas remotamente em impresso 
6.2 Descrição dos resultados das discussões ocorridas no grupo de Whatsapp a partir do desenvolvimento das tarefas propostas de forma remota 76

7 CONSIDERAÇÕES FINAIS 84 REFERÊNCIAS BIBLIOGRÁFICAS 


\section{1 - INTRODUÇÃO}

A trajetória profissional deste pesquisador, como docente em escolas públicas, foi marcada pelo desinteresse dos educandos pelos conteúdos de matemática, pois a maioria deles não consegue entender a aplicabilidade de muitos temas lecionados nas aulas. A partir dessa situação, iniciou-se uma reflexão sobre o que poderia ser alterado na prática pedagógica para despertar tal interesse pelos conteúdos abordados nas aulas dessa disciplina.

Ao analisar algumas avaliações de larga escala, como Prova Brasil, percebeuse a presença do tema "raciocínio lógico" e, dessa forma, vislumbrou-se a possibilidade do uso das Tecnologias de Informação e Comunicação (TIC) a fim de despertar o interesse nos educandos pelos conteúdos utilizando meios digitais.

A Prova Brasil avalia o desempenho do sistema educacional brasileiro a partir de testes padronizados para os $5^{\circ}$ e $9^{\circ}$ anos do Ensino Fundamental. Além da análise dos conteúdos das avaliações dessa prova, especificamente para este estudo, foram analisados o desempenho de três escolas do município de Sapucaia, Estado do Rio de Janeiro, sendo a Escola 1 situada no Centro da cidade e as Escolas 2 e 3 na zona rural para se comparar os rendimentos médios do município.

O Índice de Desenvolvimento da Educação Básica (IDEB) indica o desempenho dos educandos através da análise das informações e dados da Prova Brasil visando à melhoria no sistema educacional. No município pesquisado, é notório que há necessidade de melhorias nos índices, pois os valores atingidos nas três escolas selecionadas e o município são insatisfatórios e precisam de novas estratégias para atingir as metas. Desde 2017, o município não tem alcançado as metas propostas, já que em 2017 obteve o resultado de 4,4 e sua meta era de 4,7 e no ano de 2019 atingiu um resultado de 4,6, enquanto sua meta era 5,0.

Mediante os índices apresentados pelo município, pretende-se utilizar as TIC, como software Hot Potatoes, com a finalidade de auxiliar no problema do desinteresse dos educandos pelos conteúdos com a aplicação de tarefas de Multiplicação, e ainda, despertando o interesse dos docentes na adesão de novas práticas pedagógicas em suas aulas. Essa proposta poderá ser implementada em qualquer escola que tenha laboratório de informática. Diante das alterações no cenário educacional devido à 
Pandemia referente a Covid-19, com distanciamento necessário e adesão ao ensino remoto, ou seja, ensino utilizando os recursos tecnológicos, houve a necessidade de replanejar a utilização das TIC. Nesse caso, para esse estudo, utiliza-se o aplicativo de comunicação instantânea WhatsApp para acompanhar o desenvolvimento e aplicação das tarefas envolvendo os conteúdos supracitados, a fim de investigar se o aplicativo é uma ferramenta eficaz como suporte aos educandos através de grupos destinados a discussões referentes às tarefas.

A escola, local onde foi desenvolvida a pesquisa, atende um público da zona rural do município de Sapucaia - RJ. A pesquisa foi desenvolvida na instituição denominada como Escola 2 e em três turmas de $8^{\circ}$ ano, totalizando 56 educandos, a fim de suscitar o interesse dos docentes dos anos finais do Ensino Fundamental em iniciar os trabalhos usando os recursos tecnológicos com os alunos, o que facilitaria o desenvolvimento de outras tarefas que envolvessem as tecnologias nos anos posteriores, nesse caso, com o raciocínio lógico matemático, pois há uma grande desmotivação dos educandos pelos conteúdos.

Tendo em vista o cenário crítico de Pandemia da Covid-19 no mundo, optouse em realizar a pesquisa voltada para o desenvolvimento de uma sequência de tarefas envolvendo conteúdos como a multiplicação do Conjunto dos Números Naturais, ou seja, a Tabuada, de forma tradicional (impressa) para todos terem o acesso aos materiais enviados pela escola e, utilizando o aplicativo de troca de mensagens WhatsApp a fim de analisar a participação e as discussões do grupo no desenvolvimento das tarefas. A trajetória do desenvolvimento dessa aplicação desencadeou num primeiro Produto Educacional da nossa pesquisa, que buscou atender algumas indicações dos PCNs e da BNCC.

Há algum tempo, os PCNs e atualmente a BNCC incentivam o uso das tecnologias nas escolas, objetivando tornar os educandos cidadãos críticos e reflexivos, capazes de construir seu conhecimento e buscar seu desenvolvimento através da investigação e interação com os meios digitais. É notório que o uso das tecnologias pode agregar valores ao trabalho realizado pelos docentes, tornando suas aulas mais produtivas e dinâmicas com tarefas que envolvem o desenvolvimento do Raciocínio Lógico propostas nesta pesquisa e que serão desenvolvidas no software Hot Potatoes. Segundo a BNCC, a Educação Básica deve: 
Compreender, utilizar e criar tecnologias digitais de informação e comunicação de forma crítica, significativa, reflexiva e ética nas diversas práticas sociais (incluindo as escolares) para se comunicar, acessar e disseminar informações, produzir conhecimentos, resolver problemas e exercer protagonismo e autoria na vida pessoal e coletiva. (2018, p.11)

Essa competência da BNCC demonstra a importância da busca pelo conhecimento por parte do educando, formando um indivíduo capaz de investigar resolução para os problemas, tanto na vida pessoal quanto em sociedade. Esse desenvolvimento pode surtir melhores resultados nas avaliações externas, como Prova Brasil e PISA.

Vislumbrando a importância do Raciocínio Lógico para essa pesquisa, Machado (2000) afirma que "a lógica trata das formas de argumentação, das maneiras de encadear nosso raciocínio para justificar, a partir de fatos básicos, nossas conclusões. A lógica se preocupa com o que se pode ou não concluir a partir de certas informações."

Entende-se por Raciocínio Lógico Matemático a organização do pensamento para uma tomada de decisão coerente, ou seja, resolução de um problema de acordo com à análise dos argumentos apresentados, utilizando as TIC para incentivar e despertar interesse pelos conteúdos.

Atualmente, há inúmeros softwares e jogos eletrônicos gratuitos que podem ser utilizados como ferramentas para transformar o ensino em um ambiente atrativo para os educandos. Nessa pesquisa, será explorado o software Hot Potatoes, com o intuito de incentivar e despertar o interesse dos educandos pelos conteúdos, nesse caso, pelo Raciocínio Lógico Matemático devido às suas vantagens e facilidades no manuseio que serão elencadas no item metodologia.

Dessa forma, desenvolvemos e aplicamos tarefas de Multiplicação, do Conjunto dos Números Naturais, mais conhecida como Tabuada, para que os docentes pudessem estimular o desenvolvimento do Raciocínio Lógico Matemático em educandos do Ensino Fundamental. Conforme já descrito, devido ao cenário crítico que é vivenciado com a Pandemia, não foi possível a aplicação e análise com os educandos em laboratórios de informática como almejado inicialmente. No entanto, foi proposta e analisada uma sequência de tarefas envolvendo os mesmos conteúdos de forma tradicional, ou seja, foi enviada para cada aluno uma folha impressa com as 
tarefas para responderem e devolverem, juntamente ao material enviado pela escola nesse período de pandemia. Durante a execução dessas atividades, foi criado um grupo de WhatsApp para acompanhar o desenvolvimento das tarefas e verificar se houve a produção de significados, a partir de uma análise utilizando Modelo dos Campos Semânticos (MCS) proposto por Rômulo Lins (2002).

Ressalta-se que a referida pesquisa tem como objetivo geral desenvolver uma sequência de tarefas para educandos do Ensino Fundamental que estimulem o desenvolvimento do Raciocínio Lógico Matemático com a utilização de TIC. E, como objetivos específicos, inicialmente planejou-se estimular os educandos para que os mesmos desenvolvessem o interesse no processo de ensino e aprendizagem com atividades de Raciocínio Lógico Matemático na aplicação de tarefas desenvolvidas em software open source. Porém, visto a impossibilidade da presencialidade dos educandos em laboratórios de informática da escola e por estes não possuírem acesso à internet, adaptou-se para estimular os educandos através do desenvolvimento de uma sequência de tarefas, utilizando material impresso e comunicação por grupo de WhatsApp.

A pesquisa se classifica com abordagem qualitativa e é pautado no Modelo dos Campos Semânticos, proposto por Romulo Lins (2002) para a análise da produção de significados. Essa abordagem considera as características do educando e suas necessidades para enriquecer seu aprendizado. Para isso, são analisadas a escrita, a fala e as imagens das informações retiradas na execução da proposta de atividades enviadas aos educandos nesse período de Pandemia. Foram levados em consideração os fatos mais relevantes, objetivando construir um parecer dos resultados da análise da pesquisa da produção de significados.

Essa metodologia dispõe de características que norteiam a análise da produção de significados dos dados da pesquisa, iniciando pelo conhecimento do ambiente escolar e todo o contexto do seu campo de pesquisa, seguida da observação e registros do momento das discussões via WhatsApp. Todos os detalhes e informações obtidos são importantes nessa metodologia para organizar a conclusão da produção de significados dessa investigação qualitativa, que ocorre a partir do diálogo e da análise entre os educandos no grupo de WhatsApp. 
E, como resultado das discussões e conclusões da pesquisa referente ao desenvolvimento do Raciocínio Lógico Matemático e, atendendo ao objetivo inicial de utilizar as TICs no Ensino Fundamental, além do primeiro Produto Educacional já mencionado anteriormente, resultou também um segundo Produto Educacional com a implementação da proposta da sequência de tarefas no software Hot Potatoes, a fim de motivar novas práticas pedagógicas e despertar interesse dos educandos no processo de ensino e aprendizagem de conteúdos matemáticos. Esta proposta de atividade no Hot Potatoes, bem como o primeiro produto educacional, estão disponíveis no site do Programa de Pós-Graduação em Educação Matemática (PPGEM) $^{1}$ para que os docentes possam utilizar na inovação das práticas pedagógicas no ensino do Raciocínio Lógico matemático no laboratório de informática quando retornar o ensino presencial nas escolas ou mesmo, em situações de não presencialidade.

A referida pesquisa está organizada em sete capítulos. Neste foi abordado a inquietação que desencadeou essa investigação, a justificativa, o objetivo, a metodologia e a sua estruturação. No segundo capítulo, será apresentada a fundamentação teórica a partir de uma perspectiva sobre o uso das tecnologias no ensino da matemática, algumas noções e definições envolvendo lógica e sua importância e uma análise dos resultados em larga escala através do PISA e os resultados do IDEB de algumas escolas da cidade onde foi desenvolvida a pesquisa. No terceiro capítulo, foi realizada uma revisão de literatura sobre alguns trabalhos já realizados envolvendo o tema da pesquisa. No quarto capítulo, apresenta-se a metodologia utilizada para a obtenção do objetivo proposto. Já no quinto capítulo, verifica-se a sequência de tarefas desenvolvidas. No sexto capítulo, apresenta-se o relato do desenvolvimento e a análise dos resultados obtidos durante a execução da pesquisa. Por fim, no capítulo 7 , apresentam-se as considerações finais da investigação.

\footnotetext{
${ }^{1} \mathrm{https}: / /$ www2.ufff.br/mestradoedumat/
} 


\section{2 - FUNDAMENTAÇÃO TEÓRICA}

Nesta seção, é possível observar a importância da utilização dos recursos tecnológicos no ensino e aprendizagem dos educandos de matemática, possibilitando a investigação e estimulando a construção do conhecimento a partir da pesquisa, bem como o docente poderá notar as facilidades em seu trabalho devido ao interesse dos educandos pelas atividades envolvendo tecnologias, já que estão inseridos nesse meio, ou melhor, são nativos dessa era digital.

É possível também conhecer sobre o tema lógica e sua importância no meio educacional, percebendo que ela está associada ao raciocínio de identificar e distinguir o certo do errado de determinada situação, problema ou tarefa e, ainda, fazse presente em várias áreas de nossa sociedade, como no Direito, na Engenharia, na Matemática, na Política, na Economia e na Educação. Também serão abordados temas envolvendo o raciocínio lógico e a importância da utilização dos recursos digitais juntamente aos conteúdos com a metodologia tradicional de ensino que não utiliza tecnologias.

\subsection{Tecnologias da Informação e Comunicação (TIC) no Ensino da Matemática}

Atualmente, a tecnologia permeia todos os segmentos da sociedade. Esse fato leva a refletir sobre o uso dos recursos tecnológicos na educação, analisando as vantagens que essa ferramenta pode proporcionar ao ensino e aprendizado dos conteúdos, pois existe interesse dos educandos pelos meios digitais o qual pode facilitar a abordagem dos conteúdos e a multidisciplinaridade entre os profissionais nas unidades escolares de projetos em grupos. Tal iniciativa proporciona maior interação e participação dos integrantes do grupo, gerando também maior independência quanto à utilização dos recursos tecnológicos, uma vez que dominam essa área e são nativos dessa era. Com isso, o ensino dos conteúdos é ministrado de forma interessante, propiciando a aprendizagem, a investigação e o seu maior desenvolvimento.

Foletto afirma que,

Independente do tema a ser discutido ou problema a ser resolvido, deve ser mostrado aos alunos o quão é importante defender uma ideia 
tornando-a solução para determinada necessidade. Partindo disso ele deve ser encorajado, diga-se assim, a compreender, fazendo conexões com o conhecido, buscando o desconhecido, classificando e ordenando as suas descobertas afim de validar as suas afirmações. (FOLETTO, 2016, p.17)

A autora relata a importância do incentivo do docente para que o educando busque, através da investigação, compreender algo desconhecido utilizando suas experiências e conhecimento para concretizar um pensamento validado através de suas pesquisas.

Os recursos tecnológicos podem proporcionar, no meio educacional para aqueles que aderem a utilização em sala de aula com o objetivo de desenvolver um ensino e aprendizagem interessante e motivador, um modo que os encorajem a investigar e descobrir seus próprios resultados. O uso das tecnologias propicia um ambiente favorável à aquisição do saber, pois os educandos são instigados a resolverem atividades de seu interesse, favorecendo a aquisição do conhecimento.

A utilização dos recursos tecnológicos suscita o interesse pelos temas tratados em sala de aula. Além disso, ocorre concomitante ao ensino e aprendizagem dos educandos uma preparação destes para o mercado de trabalho e para convivência em sociedade devido aos conhecimentos que são adquiridos no seu contato com a tecnologia. Esse aprendizado, através da investigação, também permitirá aos educandos uma postura mais independente em busca do conhecimento.

Kenski (2007, p.15) afirma que "educação e tecnologia são indissociáveis". Sendo assim, devido à evolução dos meios tecnológicos no mundo, as escolas necessitam aderir as tecnologias em seu meio educacional para preparar os educandos para uma vida em sociedade, para resolução de situações-problemas e construção do conhecimento a partir do desenvolvimento tecnológico. Assim, esses educandos serão orientados e instigados a buscarem novos desafios e solucioná-los, tornandose construtores do seu próprio conhecimento.

Kenski (2012) relata ainda que,

As tecnologias estão tão próximas e presentes que nem percebemos mais que não são coisas naturais. Tecnologias que resultaram, por exemplo, em lápis, cadernos, canetas, lousas, giz e muitos outros produtos, equipamentos e processos que foram planejados e construídos para que possamos ler, escrever, ensinar e aprender. (KENSKI, 2012, p.24)

Desse modo, as tecnologias permeiam o cenário educacional e podem enriquecer esse ambiente com a utilização de ferramentas e recursos digitais que 
tendem a facilitar a preparação das aulas, os rendimentos dos conteúdos com sua praticidade, dentre outras vantagens. Em várias escolas, os docentes estão trocando a lousa por aparelhos tecnológicos, que permitem a apresentação dos conteúdos de forma mais atrativa, com as formas e figuras perfeitamente ilustradas, além das pesquisas que podem ocorrer no decorrer das aulas, caso os educandos tenham dúvidas ou questionamentos, pois o docente e o educando, com o acesso à internet, podem realizar buscas e pesquisas para solucionar e sanar dúvidas durante as aulas.

Os Parâmetros Curriculares Nacionais ( $\mathrm{PCN}$ ) vêm, há décadas, orientando os docentes a buscarem novas abordagens e metodologias para um melhor aperfeiçoamento da prática educativa, enfatizando a importância do uso das tecnologias na educação, como foi relatado ainda no ano de 1997.

O computador pode ser usado como elemento de apoio para o ensino (banco de dados elementos visuais), mas também como fonte de aprendizagem e como ferramenta para o desenvolvimento de habilidades. $O$ trabalho com o computador pode ensinar o aluno a aprender com seus erros e a aprender junto com seus colegas, trocando suas produções e comparando-as. (PCN, 1997, p.35).

Pode-se observar as vantagens que o computador pode oferecer à vida do educando, tornando-se ativo na construção de seu conhecimento a partir das ferramentas tecnológicas e suas habilidades.

Em 2018, a Base Nacional Comum Curricular (BNCC), em suas competências gerais, traz para o ensino fundamental várias propostas, dentre elas, a exploração do desenvolvimento dos educandos a fim de que este possa:

Compreender, utilizar e criar tecnologias digitais de informação e comunicação de forma crítica, significativa, reflexiva e ética nas diversas práticas sociais (incluindo as escolares) para se comunicar, acessar e disseminar informações, produzir conhecimentos, resolver problemas e exercer protagonismo e autoria na vida pessoal e coletiva. (BNCC, 2018, p.11).

Dessa forma, observa-se a necessidade de criar meios para alcançar a evolução da aprendizagem dos educandos a partir da reflexão e a crítica, tornandoos cidadãos ativos na sociedade e contribuidores de uma nação evoluída e atualizada, ou seja, dentre as inúmeras formas que o educando pode contribuir com o avanço da sociedade, a exploração da TIC é uma ferramenta que possibilita esse processo através do seu conhecimento com a expansão e distribuição destes nos meios sociais em que convive, criando grupos de indivíduos que se interessam por 
essa área, entre outros. Nesse contexto, nota-se a importância da atualização dos docentes quanto ao conhecimento e aplicação dos recursos digitais nas aulas, despertando o interesse dos educandos com o envolvimento da tecnologia no cenário educacional.

Segundo Ruiz (2003) apud Fernando et al. (2016),

O bom uso profissional e didático dos recursos que oferece a tecnologia, assentados em sólidas propostas metodológicas e pedagógicas que potencialize as TIC como meios e recursos para o ensino aprendizagem, que respondam aos diferentes ritmos da aprendizagem dos estudantes, que incentivem o pensamento criativo e crítico, a autonomia e a pesquisa, que incitem à solução de problemas atuais, que integrem diferentes disciplinas e que fomentem o domínio de idiomas e desenvolvam habilidades de comunicação e expressão. Também que oportunizem a familiarização com os avanços científicos e tecnológicos e que permitam a avaliação e o segmento dos processos (RUIZ, 2003, p. 3 apud FERNANDO et al., 2016, p.4)

O ensino com as ferramentas tecnológicas possibilita um novo cenário de ensino e aprendizagem para o educando, com suas inovações e possibilidades de investigação e aplicação. Tais recursos podem estimulá-los a criatividade e o interesse em resolver problemas do cotidiano.

Fernando et al. (2016) ainda cita dez tendências, que a Britist Broadcasting Corporation "BBC" Brasil discutiu em um seminário da Fundação Santillana e da Unesco, em São Paulo, em 2016, sobre o uso das tecnologias na sala de aula do Ensino Fundamental e o que estas podem despertar e oferecer quando aplicadas de forma adequada, metodológica e pedagógica.

Agregar valor ao trabalho do professor em vez de substituí-lo;
Melhorar processos, sem precisar mudá-los radicalmente; Tablets
estão ganhando o espaço de laptops e desktops; Pensar na internet
além dos sites de buscas e das redes sociais; Fazer conexões com o
mundo real; Estimular criação, cooperação e interação; Pensar em
novas formas de avaliar os alunos; Usar games em favor do
aprendizado; Customização e personalização e; Planejamento é
chave. (FERNANDO et al., 2016, p. 5 e 6)

Estas tendências podem contribuir com os saberes tecnológicos dos docentes, pois muitos acreditam que deverão mudar sua forma metodológica e pedagógica de ensino e aprendizagem. Contudo, os objetivos das TIC é adequar, agregar e transformar essa forma de ensinar em algo mais interessante aos educandos de acordo com as inovações de sua época. Nesse contexto, o docente terá mais sucesso na abordagem dos conteúdos com a utilização dos softwares em aparelhos celulares, 
tablets; entre outros, tornando o ensino mais atraente para nova geração de educandos.

O docente pode ainda recorrer aos recursos que a internet disponibiliza para aprimorar, exemplificar e investigar situações reais que envolvem os conteúdos através de softwares e pesquisas. Dentre essas novas formas estabelecidas de ensino e aprendizagem, ele deve criar novos meios de avaliação para seus educandos, tais como acompanhamento da interação e cooperação em grupos formados, avaliação dos resultados obtidos com a inserção dos recursos tecnológicos, interesse e assiduidade das pesquisas, entre outras. Enfim, o docente não precisa substituir seu trabalho, sua forma de atuar, suas metodologias, porém necessita de uma atualização para acompanhar a evolução que ocorre no mundo.

A questão do uso das TIC na educação vem sendo estudada por pesquisadores há algum tempo, já que a transformação tecnológica está levantando preocupações no cenário educacional bem como a educação também precisa estar atualizada para acompanhar o desenvolvimento ao seu redor.

Acredita-se que o início dessa atualização deve partir das escolas com a implementação do uso das tecnologias nas atividades com os educandos, agregando valores e possibilitando novas descobertas e investigações.

Nesse cenário, Dias (2014) considera que:

Os gestores de uma rede de ensino ou de uma escola têm, assim, um relevante papel na implementação da proposta de integração das TIC na vida da escola. Cabe-lhes a tarefa de aprender a lidar com esse novo elemento, sem tratá-lo como ente estranho ao processo de aprendizagem, mas ao contrário, liderando um processo de debate participativo e procurando inseri-lo de forma contextualizada no projeto político-pedagógico da escola. (DIAS, 2014, p. 15 e 16)

A gestão escolar terá seu papel de destaque na implementação das novas tecnologias no ensino e aprendizagem dos educandos que será trabalhada pelos docentes com apoio da direção, que lhes proporcionarão equipamentos de multimídia necessários para uma boa apresentação e execução do trabalho. Uma sugestão plausível da autora é a inclusão do uso das novas tecnologias na elaboração do Projeto Político Pedagógico (PPP) da escola, em que os docentes deverão colocar em prática a utilização dos recursos tecnológicos em suas aulas, já que sempre utilizam alguma forma de tecnologia, tais como jornal, revista ou outras atividades usando o lúdico. A atualidade vem exigindo a utilização dos meios de informação para 
que possam formar cidadãos inclusos na era digital. Com o apoio das escolas, os docentes devem buscar materiais interessantes e compatíveis com o meio social em que vivem, pois, visualizando a aplicabilidade dos conteúdos no seu meio, são motivados a pesquisarem e aprofundarem seus conhecimentos sobre eles. Nessa seleção de materiais, os docentes devem seguir algumas regras e cuidados.

Para direcionar os docentes na seleção de softwares ou outros materiais envolvendo multimídia, Lima e Giraffa (2007) apud Fonseca (2014) disponibilizaram a partir de suas pesquisas um roteiro que o docente deve estar atento:

- Definir o objetivo do programa a ser utilizado;

- Definir a forma de condução da aula e o tipo de atividade;

- Organizar o cenário de utilização;

- Organizar as interações e feedback;

- Avaliar as interações entre os alunos e o software. (LIMA e GIRRAFFA, 2007 apud FONSECA, 2014, p.30)

A partir desse roteiro, o docente conseguirá executar sua aula envolvendo os recursos tecnológicos com a proposta de incitar motivação pelos conteúdos e melhorar os resultados quanto à formação do conhecimento e desenvolvimentos dos educandos.

Conforme orientação dos autores Lima e Giraffa (2007) apud Fonseca (2014), inicialmente o docente precisa conhecer o programa a ser utilizado e quais objetivos pode atingir com determinados exercícios. Para a realização de um desenvolvimento do uso das TIC nas aulas, o docente precisará avaliar o potencial e as contribuições que the serão atribuídas pelo uso das tecnologias no processo de ensino e aprendizagem. Quanto à tecnologia a ser utilizada, outro cuidado primordial é a verificação do local a ser implementada a tarefa, tais como o estado físico das máquinas, quantidades de equipamentos e de educandos na turma, instalação do software ou aplicativos a serem utilizados, dentre outras medidas como a forma de avaliar o desempenho e interesse dos educandos nas tarefas, interações com os colegas e com os recursos que estão sendo utilizados para agregar valores ao desenvolvimento intelectual e educacional dos educandos.

Para que o docente execute seu trabalho, envolvendo os recursos digitais com êxito, Kenski salienta também, algumas observações necessárias, tais como

A organização do espaço, do tempo, o número de alunos que compõe cada turma e os objetivos do ensino podem trazer mudanças significativas para as maneiras como os professores e alunos irão utilizar as tecnologias em suas aulas. A escolha de determinado tipo 
de tecnologia altera profundamente a natureza do processo educacional e a comunicação entre os participantes. (KENSKI, 2012, p.45)

Nesse sentido, percebe-se que o planejamento e a organização do docente são primordiais na implantação de qualquer recurso tecnológico nas aulas para alcançar um índice de rendimento positivo e favorável. Mesmo assim é possível que o docente enfrente alguma dificuldade, como falha nos equipamentos, dificuldades com a internet, mesmo seguindo o roteiro e observações acima expostos, pois estará diante de um cenário novo de ensino e aprendizagem para si e para seus educandos que estão habituados com as aulas tradicionais, ou seja, sem a utilização dos recursos tecnológicos.

O sucesso das aulas envolvendo as TIC demanda do docente uma disposição na preparação das aulas, dos aplicativos, do ambiente e dos recursos a serem utilizados. Essas exigências, assim como outras, normalmente inibem o interesse dos profissionais em aderir novas ferramentas para motivar o ensino e a aprendizagem dos educandos.

Bairral (2012) descreve outros motivos que impedem e dificultam o docente em aplicar seus conteúdos com os recursos tecnológicos, sendo:

[...] uma das preocupações dos docentes e talvez uma das causas de não adesão a alguns dos recursos das TIC é a exigência de atualização constante para que realmente sirva como meio de comunicação entre professor e aluno. Outras causas, além da falta de tempo, como a preguiça e a falta de audiência dos alunos, são apontadas como razões para abandono desses recursos. (BAIRRAL, 2012, p.92)

Conforme afirmação de Bairral (2012), o docente resiste a implantação dos recursos tecnológicos em suas aulas devido à exigência de tempo e dedicação para preparação e pesquisa de materiais novos referentes aos conteúdos que serão utilizados em sala de aula. O excesso de aula/dia também é outro fator que prejudica essa atualização. Outro fato que preocupa os docentes é a necessidade de atualização dos materiais devido aos avanços tecnológicos, pois um recurso digital utilizado em um ano pode não ser mais atrativo no ano letivo seguinte, levando o mesmo a uma nova organização de materiais. Muitos docentes têm consciência da necessidade da implantação desses recursos no meio educacional, mas se deparam com essas dificuldades.

Bairral (2012) acrescenta que, 
A utilização das TIC em atividades pedagógicas requer o domínio do professor sobre a ferramenta que será utilizada e geralmente demanda a colaboração de outros setores da Instituição, tais como direção/coordenação e da equipe de suporte técnico. (BAIRRAL, 2012, p.93)

A ausência de incentivo e apoio técnico nas escolas é outro entrave na utilização das ferramentas digitais, já que muitas escolas não possuem equipe de suporte técnicos nos laboratórios de informática, o que dificulta a realização de atividades no local. E, mesmo os docentes buscando capacitações quanto à implantação dos recursos tecnológicos em suas aulas, muitas vezes eles não possuem conhecimentos tecnológicos exigidos para preparar o laboratório. Grande parte dos gestores continuam com o olhar tradicional, ou seja, que o docente deve continuar lecionando dentro de sala, sem os recursos digitais, e não os apoiam com as iniciativas tecnológicas, tratando dessas necessidades com certo descaso. Por esse fato, Bairral (2012) afirma que,

Para a realização de atividades curriculares envolvendo as TIC, é necessário um suporte técnico e a colaboração de toda a escola em diversos trabalhos correntes. Embora estejamos diante de uma era onde predominam o uso das tecnologias, em nossa realidade ainda encontramos barreiras para elevar a educação aos níveis exigidos pela sociedade tecnológica devido não só ao difícil acesso a essas tecnologias, mas, principalmente, pela falta de capacitação dos professores para a utilização das mesmas. (BAIRRAL, 2012, p.95)

É notória a necessidade de atualização das aulas com os recursos tecnológicos, mas como relatado acima, há vários entraves para concretização dessa transformação. Outro fator que contribui com o baixo índice de escolas e docentes trabalhando com os recursos digitais é a falta de capacitação dos docentes, gestores e toda comunidade escolar, pois todos os envolvidos com sistema educacional devem estar atualizados para entender e atuar de forma conjunta aos recursos tecnológicos, apoiando os docentes em suas atividades ligadas a TIC.

Há alguns anos, a dificuldade de atualização tecnológica nas escolas era apontada como a falta de recursos e equipamentos. Atualmente, essa demanda vem sendo atendida, já que as escolas públicas possuem laboratórios de informática. Contudo, ainda existe a precariedade quanto ao acesso à internet. A comunidade escolar precisa compreender que as tecnologias estão cada vez mais presentes e as mudanças e transformações irão acontecer com os avanços dessa área e, com isso, 
há necessidade de novas estratégias para atingir o sucesso esperado no ensino e aprendizagem dos educandos.

Bairral (2012) afirma que "a aplicação de estratégias que permitam aos educandos adotar uma atitude mais participativa e aos professores uma postura menos centralizadora, constituem um avanço no processo educacional" (p.88), ou seja, o docente deverá incentivar seus educandos na busca pelo conhecimento a partir da pesquisa, investigação e discussão com a mediação do docente que estará observando o seu desenvolvimento nas atividades realizadas individuais, em grupo e nas análises e interações dos resultados obtidos.

Bairral (2012) relata que,

Pensar uma educação que adote as TIC de maneira inovadora, integrada e participativa é um desafio para a maioria dos professores. Usar tecnologias modernas, mantendo antigos padrões de metodologias, de avaliação e a mesma postura do aluno e do professor em uma sala de aula, definitivamente não rompe a dinâmica tradicional da escola que, atuando dessa forma, prepara um cidadão e um profissional fora das demandas atuais. (BAIRRAL, 2012, p.84)

Bairral (2012) afirma ainda que o uso das tecnologias deve transformar o ensino e aprendizagem dos educandos deixando o método tradicional, para propor novas estratégias com os recursos digitais, uma vez que tais métodos não atendem às novas demandas da sociedade e do mercado de trabalho. $E$, para que a formação dos educandos seja eficaz, é necessária a utilização das TIC de forma inovadora, atraente, agregando valor a sua vida.

Kenski (2012) considera importante o papel das tecnologias na organização do ensino e como uma ferramenta auxiliar no ensino e aprendizagem. Kenski (2012), demonstra em sua visão que:

A maioria das tecnologias é utilizada como auxiliar no processo educativo. Não são nem o objeto, nem a sua substância, nem a sua finalidade. Elas estão presentes em todos os momentos do processo pedagógicos, desde o planejamento das disciplinas, a elaboração da proposta curricular até a certificação dos alunos que concluíram um curso. A presença de uma determinada tecnologia pode induzir profundas mudanças na maneira de organizar o ensino. (KENSKI, 2012, p.44)

A autora esclarece acima que a tecnologia contribui com o ensino e aprendizagem de várias formas direta e indiretamente, pois a sua utilização é envolvida em todas as fases do processo de desenvolvimento dos cursos. 
Diante do exposto pelos autores acima, observa-se a necessidade da utilização dos recursos tecnológicos nas práticas educacionais, permitindo aquisição e construção de novos conhecimentos a partir da investigação e exploração dos saberes que os educandos carregam em suas bagagens ao longo de sua trajetória educacional.

Acredita-se que o trabalho dos envolvidos com a educação se tornará mais eficaz com a utilização dos recursos digitais nas unidades escolares. Isso porque os educandos apresentam interesse pelos recursos digitais e a inclusão dessas ferramentas tendem a facilitar o ensino e aprendizagem do raciocínio lógico matemático através de jogos, atividades desafiadoras e interessantes, o que facilita a construção do conhecimento.

Como o objetivo é explorar o ensino e aprendizagem através do uso das tecnologias nos conteúdos envolvendo o raciocínio lógico matemático, resolveu-se aprofundar o estudo sobre o surgimento do raciocínio lógico e sua importância para os educandos.

\subsection{Raciocínio lógico matemático}

Durante os séculos XX e XXI ocorreu uma investigação de matemáticos sobre o raciocínio lógico matemático e, para expor um pouco sobre essa investigação, conta-se com as contribuições dos autores Hegenberg (1977), Nahra e Weber (1997), Machado (2000) e Fobrellone (2005) apud Barbosa (2017) e com algumas definições sobre a lógica e a importância da argumentação para chegar-se ao raciocínio lógico matemático.

Assim, apresentam-se algumas contribuições referentes ao termo lógica e sua finalidade na visão de alguns autores sobre esse tema e a importante contribuição do filósofo Aristóteles na abordagem da argumentação. O filósofo supracitado esclarece que a argumentação é a forma como se organiza os dados e/ou fatos de uma questão em busca de uma solução. Esses argumentos norteiam o pensamento para tomada de decisão coerente, ou seja, uma decisão lógica considerando os dados disponibilizados inclinados à resolução da questão.

A partir desse pensamento, acredita-se que o raciocínio lógico matemático é a consequência de uma análise de dados de determinado problema, tornando suas particularidades e tendo como opções o certo e o errado até chegar a uma conclusão 
com a análise dos argumentos. Após organização dos pensamentos e argumentos, é esperada uma tomada de decisão lógica e correta.

Machado (2000) demonstra a importância de Aristóteles para o estudo da argumentação que norteia a compreensão da lógica e relata que,

$\mathrm{Na}$ Grécia antiga, há mais de dois mil anos, viveram inúmeros pensadores cujas ideias permanecem vivas até os dias de hoje. Aristóteles, que viveu no século IV antes de Cristo, foi um deles. Esse filósofo pode ser considerado o primeiro a se preocupar com o estabelecimento de regras para a argumentação. Ele fez um estudo minucioso de certos tipos básicos de argumentos, estabelecendo regras para distinguir os que são válidos daqueles que não o são. (MACHADO, 2000, p.13).

É fato que o estudo da lógica está sendo investigado há muito tempo, visto sua importância na resolução de problemas do cotidiano. O indivíduo convive com situações em que precisa realizar suas escolhas e, para que essas sejam feitas coerentemente, são necessários argumentos e lógica para chegar a melhor decisão.

Para aprofundar o entendimento de lógica, apresentam-se algumas definições dadas por autores, como a de Hegenberg (1977), que considera a lógica sendo, "a descoberta de leis gerais de encadeamento de conceitos para formar juízos e de encadeamento de juízos para formar raciocínios" (p.14).

Hegenberg (1977) reforça ainda que,

A lógica tem como um de seus objetivos a formulação de critérios que permitam uma análise da legitimidade dos argumentos - distinguindo argumentos legítimos e ilegítimos. Estudar lógica, portanto, parece um tanto paradoxal, no seguinte sentido: não se pode, aparentemente, estudar lógica sem usá-la. Para construir uma "ciência do pensamento correto" é preciso pensar corretamente: se o estudo não caminhar sob a orientação da lógica, pode carecer de fundamento, transformando-se em algo arbitrário ou incoerente. A lógica, em certa medida, precede a si mesma. (p.31).

Conforme relata o autor, a lógica contribui para a tomada das decisões coerentes partindo da verificação da legitimidade dos argumentos. A partir de uma análise lógica de determinada situação problema, o indivíduo toma decisões incoerentes desnecessariamente, pois a lógica mostra quais decisões devem ser tomadas, ou seja, o erro é opcional e a decisão correta é demonstrada a partir da análise lógica dos argumentos.

Nahra e Weber (1997) corroboram afirmando que "A lógica é uma ciência que pode ser aplicada em várias outras ciências e em vários ramos do conhecimento humano." (p. 121). 
Nesse sentido, pode-se abordar a lógica através da interdisciplinaridade, contribuindo para o desenvolvimento do processo de ensino e aprendizagem dos educandos de forma diferenciada, utilizando recursos que sejam de seu interesse.

Os autores Nahra e Weber (1997) expõem alguns ramos que a Lógica pode ser aplicada,

\begin{abstract}
A Lógica é de fundamental importância nas ciências da computação. Quando o profissional de informática elabora um programa, ele geralmente faz o "fluxograma", ou seja o "desenho" deste programa, que nada mais é do que a determinação dos passos lógicos necessários para a sua elaboração; a partir destes passos iniciais, os programas são desenvolvidos. A Lógica é importante para as atividades desenvolvidas pelo psicólogo. Várias inferências sobre os princípios que movem as ações das pessoas podem ser descobertas a partir da análise lógica de seus argumentos. A análise destes princípios permite a descoberta de traços característicos da personalidade. $\mathrm{Na}$ atividade desenvolvida pelo sociólogo, a Lógica também é útil. O preparo de uma pesquisa de opinião deve levar em conta várias considerações de ordem lógica, tanto para escolher o tipo de amostra adequada quanto para a elaboração do questionário que nunca pode se ambíguo. (p. 121)
\end{abstract}

Além das aplicações apresentadas acima, há outros exemplos em que a Lógica está inserida, tais como, a Engenharia, em que o responsável por uma construção realiza suas atividades a partir de uma ordem lógica, tais como a fundação, desenvolvimento e conclusão de uma obra. Todavia, no decorrer desses processos deverá tomar decisões que não constam no projeto para o desenrolar da obra. Nesse caso, o engenheiro vai averiguar os dados e argumentos seguindo uma lógica para tomar a melhor decisão. Outro exemplo é na educação, quando os conteúdos são separados e selecionados de acordo com a escolaridade, cada conteúdo aplicado numa série escolar, seguindo uma lógica para facilitar a compreensão dos conteúdos. Nesse caso, o educando necessita conhecer os conteúdos seguindo um cronograma, uma lógica, pois depende de um determinado aprendizado para compreender um seguinte, que normalmente, tem uma relação direta entre si.

Quando o assunto é Lógica, são retratadas situações do cotidiano, presentes a todo instante. Por exemplo: "Se devo ir ou não ao banco", nesse caso, há vários argumentos envolvendo a lógica para analisar a tomada de decisão. Analisar o que será executado no banco e o horário para averiguar riscos de assalto, verificar a disponibilidade de tempo para ir até lá e o dia do mês referente ao movimento mensal, já que, normalmente, recebe maiores movimentações até o décimo dia útil, dentre outras análises que podem ser realizadas. 
Atualmente, as crianças nascem num cenário em que a tecnologia predomina nas diversões, nos desenhos, nos jogos, nas atividades escolares virtuais, ou seja, crescem nesse meio tecnológico o qual dominam e se interessam. Considerando que o objetivo do trabalho nesta investigação é propor e analisar tarefas envolvendo o pensamento lógico-matemático com uso de recursos tecnológicos para atraí-los e despertar o desejo pela investigação, Forbellone (2005) apud Barbosa et al. (2017, p.4) aponta que,

A lógica é a arte de bem pensar e estuda a correção do raciocínio. Tudo o que envolve a computação tem como origem a construção lógica dos componentes, softwares e conexões. Da mesma forma, que na leitura ou escrita, o raciocínio lógico na resolução de problemas matemáticos é um fator de extrema importância. Um grande número de instituições tem usado o computador como ferramenta de apoio ao ensino. Porém o uso dele normalmente é voltado para a realização de pesquisas, formatação de trabalhos, realização de cálculos em planilhas, e atividades que, em geral, são de conhecimento básico, operacional e que não exigem grandes desafios lógicos.

Conforme citação acima, o computador ainda tem sido utilizado nas escolas como uma ferramenta de apoio para pesquisas e execução/elaboração de trabalhos. Sendo que poderiam ser utilizados com outras finalidades, como a utilização de softwares que possibilitam a investigação e a construção do conhecimento e do raciocínio lógico. Os educandos dessa atualidade estão conectados aos recursos tecnológicos facilitando o desenvolvimento de tarefas nesse sentido.

Outro fato interessante são as pesquisas envolvendo a exploração dos conhecimentos computacionais nas escolas, pois incentivam os educandos a buscarem caminhos e soluções para desafios propostos, despertando neles o interesse pelos conteúdos. Para confirmar a importância dessas pesquisas, Azevedo (2015) afirma que,

[...] é preciso explorá-las no sentido de contribuir à construção significativa do conhecimento, em que se favoreça o desenvolvimento do pensamento lógico-dedutivo, argumentativo e crítico-reflexivo dos estudantes. Um dos caminhos possiveis para isso é exploração (de forma construtiva) da linguagem computacional gráfica. Isso porque ela é uma poderosa ferramenta tecnológica que possibilita ao estudante ser autor dos processos criativos e construtivos do conhecimento. (AZEVEDO 2015, p.2)

De acordo com o autor, o educando precisa de oportunidades para explorar os recursos tecnológicos, podendo assim desenvolver seu potencial para a linguagem computacional gráfica com a construção de sequências de blocos e promover o 
interesse pela programação, que tem como parâmetros a Lógica ou outras áreas afins. Esse aluno é instigado a buscar novas descobertas que surgem com o manuseio das mídias, elevando seu interesse pela exploração e criação de novos conhecimentos. Os jogos que envolvem Lógica, através dos recursos digitais, também contribuem no desenvolvimento dos educandos, uma vez que são instigados a analisar e refletir sobre as informações para uma tomada de decisão lógica e coerente, formando assim uma estratégia para finalizar a jogada com sucesso.

Diante disso, podemos notar a importância do pensamento computacional inserido nessas atividades e no estímulo para essa geração de educandos, através de novas investigações e aprendizagem que essa ferramenta pode proporcionar. Para Wing (2006) apud Marques (2019) e definido pela Sociedade Brasileira de Computação - SBC, que o Pensamento Computacional pode ser entendido como "a capacidade de sistematizar, representar, analisar e resolver problemas computacionais e cotidianos". Dessa forma, acredita-se na possibilidade de uma relação direta entre o raciocínio lógico e o pensamento computacional a fim de despertar interesse pela investigação e pelos conteúdos com essas ferramentas.

Dias (2016) afirma que,

A proposta de trabalhar a matemática e o raciocínio lógico aliado aos princípios do pensamento computacional tem muito a ver com essa autonomia, com a perspectiva de desenvolver o lado cognitivo, onde o aluno busca suas próprias alternativas, propõe soluções para problemas do seu dia a dia, e assim vai internalizando os conceitos aprendidos. (p.12)

Nesse caso, o autor sugere a interdisciplinaridade do pensamento computacional com a matemática como forma de despertar o interesse dos educandos pelos conteúdos, pois não basta o docente aplicar um conteúdo envolvendo tecnologia, se este não for do interesse dos educandos.

Herminio e Borba (2010, p. 115) afirmam a importância de "proporcionar aos alunos oportunidades de identificar e estudar situações-problemas de sua realidade, despertando maior interesse e desenvolvendo um conhecimento mais crítico e reflexivo em relação aos conteúdos matemáticos".

O docente deverá estar atento ao ambiente e à convivência de seus educandos para relacionar os conteúdos a suas práticas diárias, dando significados aos conteúdos abordados. Assim, possibilitará a eles um maior interesse por tal conhecimento e sua aplicabilidade no cotidiano. 
Rangel (1992) apud Silveira (2012, p.2), apresenta Piaget, que afirma que "o raciocínio lógico-matemático é uma construção que resulta da ação mental da criança sobre o mundo", ou seja, sua mente está associada às novas tecnologias disponibilizadas em nosso meio. Sendo assim, o ensino da Matemática será facilitado com as atividades que desenvolvam seu raciocínio lógico e a utilização de ferramentas digitais, apropriando tais tarefas para cada faixa etária.

\subsubsection{Tecnologias para o pensamento lógico matemático}

A Matemática é uma disciplina imprescindível na vida do educando, uma vez que este conhecimento será utilizado em seu cotidiano. Por exemplo, ao calcular o tempo de sua residência até a escola, na compra de pão para o café da manhã, num orçamento de materiais escolares, entre outras. Mas, há educandos que não conseguem adquirir uma aprendizagem satisfatória em sala de aula para realizar esses cálculos básicos.

O ensino e aprendizagem dos conteúdos matemáticos podem ser explorados através de softwares e jogos com os recursos tecnológicos, envolvendo o raciocínio lógico para desenvolver as habilidades e estimular a construção do saber matemático.

Através do INEP (2018), observa-se os resultados do Programa Internacional de Avaliação de Estudantes (PISA), que é referência de avaliação em larga escala no contexto mundial. Nela, nota-se a ausência de evolução do Brasil quanto ao ensino de Matemática dentre os países selecionados e avaliados em 2018. Vale ressaltar que restringe-se essa observação quanto aos índices referentes à Matemática. Segundo INEP (2018), as variações nos seus resultados não são satisfatórios, pois o Brasil (384 pontos) está 108 pontos abaixo da média dos estudantes dos países da Organização para a Cooperação e Desenvolvimento Econômico (OCDE) conforme Quadro 1.

QUADRO 1: Média por edição dos países selecionados matemática - PISA 2018

\begin{tabular}{|l|l|l|l|l|l|l|}
\hline \multirow{2}{*}{ PAíS } & \multicolumn{6}{c|}{ MÉDIA } \\
\cline { 2 - 8 } & 2003 & 2006 & 2009 & 2012 & 2015 & 2018 \\
\hline Coreia & 542 & 547 & 546 & 554 & 524 & 526 \\
\hline Canadá & 532 & 527 & 527 & 518 & 516 & 512 \\
\hline Finlândia & 544 & 548 & 541 & 519 & 511 & 507 \\
\hline Portugal & 466 & 466 & 487 & 487 & 492 & 492 \\
\hline
\end{tabular}




\begin{tabular}{|l|l|l|l|l|l|l|}
\hline Espanha & 485 & 480 & 483 & 484 & 486 & 481 \\
\hline Estados Unidos & 483 & 474 & 487 & 481 & 470 & 478 \\
\hline Uruguai & 422 & 427 & 427 & 409 & 418 & 418 \\
\hline Chile & - & 411 & 421 & 423 & 423 & 417 \\
\hline México & 385 & 406 & 419 & 413 & 408 & 409 \\
\hline Costa Rica & - & - & 409 & 407 & 400 & 402 \\
\hline Peru & - & - & 365 & 368 & 387 & 400 \\
\hline Colômbia & - & 370 & 381 & 376 & 390 & 391 \\
\hline Brasil & 356 & 370 & 386 & 389 & 377 & 384 \\
\hline Argentina & - & 381 & 388 & 388 & - & 379 \\
\hline Panamá & - & - & 360 & - & - & 353 \\
\hline Repúplica Dominicana & - & - & - & - & 328 & 325 \\
\hline
\end{tabular}

Fonte: Autor, apud Inep, com base em OCDE.

É possível observar que a educação no Brasil, comparado com outros países, não evoluiu nas últimas décadas de forma satisfatória, pois continua com baixos índices. Esse fato leva a refletir e analisar o cenário escolar a partir de novas estratégias para mudar esses índices.

Os índices de rendimentos do município e das escolas de Sapucaia - RJ, (munícipio foco da pesquisa) apresentados a seguir, mostram uma variação no ensino e aprendizagem dos educandos. Nos Quadros 2, 3, 4 e 5 abaixo será possível perceber uma disparidade entre os rendimentos no decorrer dos anos.

Quadro 2 - Rendimentos na Prova Brasil do município

\begin{tabular}{|c|c|c|}
\hline \multicolumn{3}{|c|}{ IDEB - Resultados e Metas } \\
\hline ANO & META & RESULTADO \\
\hline 2005 & & 3,2 \\
\hline 2007 & 3,2 & $\mathbf{3 , 5}$ \\
\hline 2009 & 3,4 & $\mathbf{3 , 8}$ \\
\hline 2011 & 3,7 & 3,3 \\
\hline 2013 & 4,1 & $\mathbf{4 , 4}$ \\
\hline 2015 & 4,4 & $\mathbf{4 , 6}$ \\
\hline 2017 & 4,7 & 4,4 \\
\hline 2019 & 5,0 & 4,6 \\
\hline 2021 & 5,2 & \\
\hline
\end{tabular}

Fonte: http://ideb.inep.gov.br/resultado/

No Quadro 2 é possível observar que nos últimos anos as estratégias utilizadas na educação do município não vêm sendo satisfatórias o suficiente para atingir as metas propostas para o ensino, já que não foi possível manter os resultados dos anos anteriores. Vale ressaltar que o município atende algumas escolas localizadas na 
zona rural e de difícil acesso, ou seja, há dificuldades de transporte para chegar à escola, precariedade de fornecimento de energia elétrica, de internet, dentre outras.

Outro fato relevante no município é o baixo quantitativo de educando, por exemplo, nas turmas do $5^{\circ}$ e $9^{\circ}$ ano de escolaridade, impedindo que os resultados dos participantes de algumas escolas sejam divulgados, pois não atingem o mínimo exigido pelo INEP, sendo no mínimo, 10 educando ou $50 \%$ dos matriculados na série em escolas menores. Os resultados destacados em negrito demonstram os períodos em que o município atingiu suas metas.

A seguir, apresentaremos detalhes do rendimento de três escolas do munícipio, sendo uma situada no perímetro urbano e as demais, na zona rural. Como informado no item introdução, serão tratadas como Escola 1, Escola 2 e Escola 3 para manter o sigilo da identificação das mesmas.

No Quadro 3, é possível observar o rendimento da Escola 1, localizada na região central do município.

Quadro 3 - Rendimentos na Prova Brasil da escola 1

\begin{tabular}{|c|c|c|}
\hline \multicolumn{3}{|c|}{ ESCOLA 1 } \\
\hline IDEB - Resultados e Metas \\
\hline 2005 & META & RESULTADO \\
\hline 2007 & & \\
\hline 2009 & & 3,3 \\
\hline 2011 & & $\mathbf{3 , 8}$ \\
\hline 2013 & 3,5 & $\mathbf{4 , 1}$ \\
\hline 2015 & 3,8 & $\mathbf{4 , 3}$ \\
\hline 2017 & 4,0 & $*$ \\
\hline 2019 & 4,3 & \\
\hline 2021 & 4,6 & \\
\hline
\end{tabular}

Fonte: http://ideb.inep.gov.br/resultado/

Como pode-se notar na Quadro 3, a Escola 1 vem apresentando resultados satisfatórios e atingindo suas metas. Contudo, essas metas e resultados precisam melhorar, pois estão abaixo do esperado para as metas municipais. Os números destacados demonstram os resultados positivos da escola. Em 2019, a quantidade de participantes no SAEB foi insuficiente para que os resultados fossem divulgados.

No Quadro 4, será possível observar o rendimento da Escola 2 localizada na zona rural do município.

Quadro 4 - Rendimentos na Prova Brasil da escola 2

\begin{tabular}{|c|}
\hline ESCOLA 2 \\
\hline IDEB - Resultados e Metas \\
\hline
\end{tabular}




\begin{tabular}{|c|c|c|}
\hline ANO & META & RESULTADO \\
\hline 2005 & 3,1 & $\mathbf{3 , 1}$ \\
\hline 2007 & 3,2 & $\mathbf{3 , 5}$ \\
\hline 2009 & 3,5 & $\mathbf{3 , 7}$ \\
\hline 2011 & 3,9 & $\mathbf{4 , 3}$ \\
\hline 2013 & 4,3 & $\mathbf{5 , 1}$ \\
\hline 2015 & 4,6 & $*$ \\
\hline 2017 & 4,8 & 4,5 \\
\hline 2019 & 5,1 & \\
\hline 2021 & & \\
\hline
\end{tabular}

* Em 2017, o número de participantes no SAEB foi insuficiente para que os resultados fossem divulgados

Fonte: http://ideb.inep.gov.br/resultado/resultado/resultado. seam?cid=3358320

Observando o Quadro 4, nota-se que a Escola 2 apresenta melhores resultados do que a Escola 1, pois conseguiu atingir suas metas em vários anos, além das metas propostas para o município. Nas últimas avaliações, em 2017 e 2019 a escola não apresentou resultados satisfatórios, ficando abaixo da meta da escola e do município, motivos estes, para uma reflexão por parte de seus gestores.

No Quadro 5, apresentamos os rendimentos da Escola 3, também localizada na zona rural do município.

Quadro 5 - Rendimentos na Prova Brasil da escola 3

\begin{tabular}{|c|c|c|}
\hline \multicolumn{3}{|c|}{ ESCOLA 3 } \\
\hline \multicolumn{3}{|c|}{ IDEB - Resultados e Metas } \\
\hline ANO & META & RESULTADO \\
\hline 2005 & & \\
\hline 2007 & & \\
\hline 2009 & & \\
\hline 2011 & & $\mathbf{4 , 4}$ \\
\hline 2013 & & $\mathbf{5 , 2}$ \\
\hline 2015 & 4,7 & \\
\hline 2017 & 4,9 & \\
\hline 2019 & & \\
\hline 2021 & & \\
\hline
\end{tabular}

Fonte: http://ideb.inep.gov.br/resultado/ 
A Escola 3 apresenta um rendimento mediano, ou seja, conseguiu atingir sua meta em 2019. A escola iniciou sua participação na Prova Brasil recentemente devido ao baixo contingente de educando matriculados. Isso porque não atendeu aos requisitos necessários para ter o desempenho calculado. Não há informações disponíveis quanto aos anos anteriores.

Mediante os dados elencados nos quadros acima, nota-se a importância de alguma intervenção no cenário educacional quanto ao ensino e aprendizagem dos educandos. Para isso, conta-se com a BNCC que ressalta sobre,

O estímulo ao pensamento criativo, lógico e crítico, por meio da construção e do fortalecimento da capacidade de fazer perguntas e de avaliar respostas, de argumentar, de interagir com diversas produções culturais, de fazer uso de tecnologias de informação e comunicação, possibilita aos alunos ampliar sua compreensão de si mesmos, do mundo natural e social, das relações dos seres humanos entre si e com a natureza.(2018, p. 56).

Nota-se a importância de abordar os conteúdos de matemática favorecendo a investigação dos educandos na construção do saber, já que a educação precisa dessa transformação para tornar o ensino algo interessante e natural. Assim, os educandos poderão realizar suas pesquisas e descobertas e, com a mediação do docente, chegar aos resultados e analisar suas conclusões.

Prieto considera importante o papel do docente nesse novo cenário envolvendo as TIC para auxiliar e mediar as novas descobertas, pois

Os valores lógicos (Verdadeiros ou Falsos) existentes nas relações humanas nem sempre são fáceis de serem compreendidos ou identificados e para estudá-los caberá ao professor, motivar, orientar, organizar e dirigir, seus alunos propondo atividades que estimulem suas múltiplas inteligências, sem inibir o processo criativo e interferir em seus estágios de desenvolvimento.(2018, p.5)

Assim, o docente, através da seleção de materiais do interesse dos educandos, do meio social que vivem, poderá contribuir com o processo de ensino e aprendizagem e possibilitar um estudo mais atrativo para os mesmos, pois poderão visualizar os resultados em sua realidade. Muitos educandos questionam o porquê de estudarem determinados conteúdos matemáticos e a sua relação com a realidade.

Outro papel do docente quanto ao uso das tecnologias e na aplicação dos valores lógicos é a mediação e a coordenação das atividades que demandam controle 
para que os educandos não se desviem dos objetivos traçados para determinado conteúdo.

O uso das tecnologias pelos educandos de forma adequada pelos docentes pode favorecer o desenvolvimento do seu raciocínio lógico, porque

O Raciocínio Lógico Matemático compreende um conjunto de técnicas, métodos e processos que, sistematizados, organizados, desencadeados e, sequencialmente estruturados através das interações entre as múltiplas Inteligências Funcionais promovidas pelo cérebro, facilitam a compreensão e a resolução de problemas. (PRIETO, 2018, p.2).

Esse desenvolvimento da inteligência, na compreensão e na resolução dos problemas matemáticos, também facilitados pelo interesse às tecnologias, levam o educando ao crescimento educacional, tornando-o um cidadão ativo na sociedade diante das situações que surgirão no decorrer de sua vida educacional, profissional, social, entre outras, considerando que muitos cidadãos escolhem suas profissões de acordo com o interesse por determinada área estudada ainda no Ensino Fundamental. Nesse sentido, a BNCC afirma que,

a escola pode contribuir para o delineamento do projeto de vida dos estudantes, ao estabelecer uma articulação não somente com os anseios desses jovens em relação ao seu futuro, como também com a continuidade dos estudos no Ensino Médio. Esse processo de reflexão sobre o que cada jovem quer ser no futuro, e de planejamento de ações para construir esse futuro, pode representar mais uma possibilidade de desenvolvimento pessoal e social. (2018, p. 60).

$\mathrm{Na}$ fase educacional, Ensino Fundamental, muitos são os interesses dos educandos, tais como jogos e redes sociais. Nesse sentido, o docente pode orientar seus educandos, como citado na BNCC, quanto as decisões que deverão tomar a partir do Ensino Médio, quando muitos ingressam no mercado de trabalho, almejam estudar nas universidades ou trabalhar e estudar, dependendo da realidade social dos indivíduos. Muitas são as orientações dadas nessa fase e o docente poderá contribuir com a tomada de decisão dos educandos a partir de suas aulas atualizadas e interessantes, permitindo-Ihes uma investigação e decisão mais concreta sobre sua vida.

Acredita-se que o docente pode envolver as tecnologias em suas aulas para promover um ensino mais significativo na vida dos educandos, pois visualização, 
construção e investigação possibilitam uma aprendizagem dos conteúdos de forma interessante. Sendo assim, o docente estará trabalhando várias habilidades dos educandos na percepção dos objetos e sua finalidade em seu cotidiano, resolução de problemas lógicos, estatísticos, financeiros e, consequentemente, iniciarão o processo de produção de significados através da investigação e aplicação dos recursos tecnológicos que envolvem o pensamento lógico-matemático.

Para verificação da produção de significados dos resultados dessa pesquisa, foi utilizado o Modelo dos Campos Semânticos, de Rómulo Lins. No próximo tópico, será aprofundado e explorado melhor esse tema.

\subsection{Modelos dos Campos Semânticos}

Para analisar as atividades propostas aos educando de forma tradicional (impressa) e o desenvolvimento do pensamento lógico matemático, assim como, sua contribuição para o ensino e aprendizagem dos educando, será utilizado o Modelo dos Campos Semânticos (MCS) a fim de analisar a produção de significados e identificar as dificuldades e a lógica utilizada pelos educandos, como a forma de resolução dos problemas.

Silva e Lins (2003) sugerem algumas orientações para que o docente realize o processo de produção de significados de forma eficiente em sua prática, conforme descrito a seguir,

i) a constituição de objetos - coisas sobre as quais sabemos dizer algo e dizemos - que nos permite observar tanto os novos objetos que estão sendo constituídos quanto os significados produzidos para esses objetos; ii) a formação de um núcleo: o processo que envolve as estipulações locais, as operações e sua lógica; iii) a fala da direção de interlocutores; e, iv) as legitimidades, isto é, o que é legítimo ou não dizer no interior de uma atividade. (p.10)

O presente trabalho pretende aplicar todo o processo de produção de significados orientado por Silva e Lins (2003), quando da execução das atividades propostas e aplicada para os educando do Ensino Fundamental II, com a finalidade de verificar a produção de significados referente ao pensamento lógico matemático.

Segundo Lins (2002) apud Paula (2012),

Observamos em nossa prática docente um consenso entre Educadores Matemáticos da importância de se dar voz ao aluno. $\mathrm{Na}$ nossa perspectiva, o MCS nos permite isso, pois apresenta noções que possibilitam uma análise, que a nosso ver, se torna mais 
consistente na medida em que apresenta categorias que nos possibilitam, por exemplo, tratar do que é matemático junto com o que não é matemático. (LINS et al, 2002 apud PAULA, 2012, p.40)

A prática docente em conjunto com o MCS, pode possibilitar o desenvolvimento do processo de ensino e aprendizagem dos educandos, pois o modelo possibilitará ao docente conhecer seus educandos e seus interesses através do diálogo e da observação. Dessa forma, o docente poderá selecionar materiais de acordo com o perfil da turma, possibilitando a comunicação e interação dos educandos com esses recursos.

Para elaboração do processo de produção de significados, serão analisados alguns conceitos de palavras centrais para essa análise, tais como significado, noções de conhecimentos, produção de significado e campo semântico.

Para Vigotsky (1987, p.104) apud Silva (2003, p.40),

O significado das palavras é um fenômeno de pensamento apenas na medida em que o pensamento ganha corpo por meio da fala, e só é um fenômeno da fala na medida que esta é ligada ao pensamento, sendo iluminada por ele. É um fenômeno do pensamento verbal, ou da fala significativa - uma união da palavra e do pensamento.

Pode-se afirmar que o significado de determinada palavra se dá a partir do seu pensamento conjugado a pronúncia da mesma, ou seja, é ação do pensamento com a fala que atribui significado a alguma coisa.

Silva (2003) contribui trazendo uma noção de conhecimento,

[...] os três aspectos-chave para conhecimento são: a crença, a afirmação e a justificação. O sujeito acredita naquilo que está afirmando, o que implica que ele acredita estar autorizado a ter aquela crença. Mas não é suficiente que a pessoa acredite e afirme; é preciso também que ela justifique suas crenças-afirmações para que a produção do conhecimento ocorra. Porém, o papel da justificação não é explicar a crença-afirmação, mas tornar sua enunciação legítima, o que faz com que as justificações tenham um papel central no estabelecimento do conhecimento do sujeito. (p.18)

O conhecimento é visto como a união da crença e afirmação referente a algo com sua comprovação a partir da justificação, que ocupa o papel de tornar verdadeira a informação dada pela afirmação inicial. Segundo Silva (2003), essa justificação pode ser dada de formas diferentes, de acordo com o grau de instrução dos envolvidos ou da idade dos mesmos. Nesse sentido, Silva (2003), contribui ainda com a definição de Campo Semântico,

Campo semântico é entendido como a atividade de produzir significados em relação a um núcleo. Alternativamente, diremos que 
uma pessoa está operando em um Campo Semântico toda vez que ela estiver produzindo significado em relação a um núcleo no interior de uma atividade. (p. 77)

Neto (2015), colabora afirmando que,

Campo Semântico é o deslocamento de intencionalidade psicoenergética de um indivíduo (mandante) para outro (executor). Essa pulsão transferencial de um organismo para outro pode também ser mediada por um terceiro: $A$ emite $B$ para $C$, quando $B$ encontrará C, C encontrará segundo A. Cada aluno é capaz de produzir significados diferentes, por meios diferentes de produção de significados numa mesma enunciação. (p.3)

Pode-se notar que o campo semântico é a produção de significados de determinada atividade e que os resultados podem variar de acordo com os educandos, ou seja, o campo semântico é o conjunto de caminhos que o aluno segue para execução das tarefas.

O conhecimento do termo "Campos Semânticos" contribuirá para entendimento e análise do processo de produção de significados dos educando envolvidos na análise das tarefas propostas nesta pesquisa, em que os educandos serão motivados e acompanhados por um grupo de WhatsApp objetivando orientar e registrar os pontos principais das interações que envolvem as dificuldades e resoluções das tarefas dessa pesquisa. 


\section{3 - REVISÃO DE LITERATURA}

Esta revisão da literatura tem como objetivo demonstrar a relevância do tema Raciocínio Lógico Matemático desenvolvido por meio das Tecnologias de Informação e Comunicação na visão de autores que realizaram pesquisas nessa área.

Para elaboração deste trabalho foi realizado um mapeamento sistemático de materiais que contribuíram com nossa pesquisa. $O$ método utilizado para 0 mapeamento consiste na descrição do planejamento e objetivos da busca, bem como os critérios de seleção e exclusão, base de dados, execução da revisão de literatura e, por fim, a descrição dos trabalhos selecionados, conforme apresentação a seguir.

\subsection{Planejamento e execução da revisão de literatura}

A partir da definição do tema Desenvolvimento do Raciocínio Lógico Matemático com o uso de Tecnologias da Informação e Comunicação para o Ensino Fundamental definido, iniciaram as pesquisas tendo como palavras-chaves "raciocínio lógico-matemático e tecnologias", a fim de selecionar trabalhos condizentes com o objeto de pesquisa.

As pesquisas iniciaram-se no segundo semestre de 2018 durante o desenvolvimento da disciplina de Prática Científica para Docentes Pesquisadores no Programa de Mestrado em Educação Matemática, em que foram apresentadas algumas instruções quanto à realização de pesquisas. Tais orientações incluíram em como pesquisar em bases de dados, em anais de encontros nacionais e internacionais, banco de dados de universidades, periódicos, revistas, livros, entre outras.

\subsection{Objetivo da revisão de literatura}

A nossa pesquisa buscou trabalhos que investigaram temas relacionados com o Raciocínio Lógico e a utilização das Tecnologias com educandos, apresentando e 
demonstrando essas contribuições como auxílio no ensino e aprendizagem. Para isso, foram pesquisados artigos, livros, sites referentes ao ensino e aprendizagem envolvendo o raciocínio lógico-matemático e as tecnologias de informação e comunicação.

\subsection{Bases de dados}

Para analisar e selecionar os materiais, houve buscas no Banco de dissertações do Mestrado Profissional de Educação Matemática da Universidade Federal de Juiz de Fora (UFJF) ${ }^{2}$, Anais do Encontro Brasileiro de Estudantes de PósGraduação em Educação Matemática (EBRAPEM) ${ }^{3}$, Anais do Encontro Mineiro de Educação Matemática (EMEM) $)^{4}$, Anais do Encontro Nacional de Educação Matemática (ENEM) $)^{5}$, Anais do Colóquio de Educação Matemática $(\mathrm{CEMA})^{6}$, Anais do Simpósio Brasileiro de Informática na Educação $(\mathrm{SBIE})^{6}$ e Revista Brasileira de Informática na Educação (RBIE) $)^{7}$

\subsection{Critérios de seleção e exclusão}

Kitchenham (2004) apud Silva (2018) considera necessário esse processo de seleção e exclusão dos trabalhos utilizando os critérios de leitura dos títulos, palavraschaves e resumo para avaliar os trabalhos encontrados, analisando sua finalidade e importância para pesquisa que está em andamento.

\footnotetext{
${ }^{2}$ www.ufjf.br/mestradoedumat/dissertacoes-defendidas;

${ }^{3}$ http://www.ufff.br/ebrapem2015

${ }^{4}$ http://www.ufjf.br/emem/

${ }^{5}$ http://www.sbembrasil.org.br/sbembrasil/index.php/anais/enem

${ }^{6}$ http://www.ufff.br/coloquioedumat/anais/

${ }^{6} \mathrm{https}: / / \mathrm{www}$.br-ie.org/pub/index.php/sbie/index

${ }^{7}$ https://www.br-ie.org/pub/index.php/rbie
} 
Como critérios iniciais, foram analisados os títulos e resumos para avaliação, seleção e exclusão dos textos no início da pesquisa, no segundo semestre de 2018 , pelo presente autor que selecionou os trabalhos com temas adequados com a pesquisa para avaliar e analisar durante este semestre.

Após a análise dos títulos e resumos de 36 trabalhos, foram selecionados inicialmente doze textos para uma leitura prévia. Terminada a leitura e análise da relevância dos mesmos, selecionou-se seis textos para um estudo mais aprofundado, que pretende embasar essa revisão de literatura, conforme apresentado no Quadro 6:

Quadro 6 - Seleção de pesquisas utilizadas na revisão de literatura

\begin{tabular}{|c|c|c|c|c|}
\hline ÁREA & ANO & AUTOR(ES) & LOCAL & TEMA \\
\hline Ensino e TIC & 2012 & $\begin{array}{l}\text { Coelho, Patrícia } \\
\text { Margarida Farias }\end{array}$ & UFMG & $\begin{array}{l}\text { Os Nativos Digitais e as } \\
\text { Competências Tecnológicas } \\
\text { demostrando as habilidades das } \\
\text { crianças e adolescentes } \\
\text { nascidos após o ano de } 1980 \text { e } \\
\text { a importância do uso de } \\
\text { dispositivos móveis e games } \\
\text { educacionais para incentivar a } \\
\text { aprendizagem dos conteúdos } \\
\text { nas escolas }\end{array}$ \\
\hline $\begin{array}{l}\text { TIC } \\
\text { RACIOCINÍO } \\
\text { LÓGICO }\end{array}$ & 2016 & $\begin{array}{ll}\text { Kologeski, } & \text { Anelise } \\
\text { Lemke; } & \\
\text { Silva, } & \text { Camille } \\
\text { Grings; } & \\
\text { Barbosa, Débora } \\
\text { Nice Ferrari; } \\
\text { Mattos, Rodrigo } \\
\text { Reis; } \\
\text { Miorelli, } \\
\text { Teresinha. }\end{array}$ & $\begin{array}{l}\text { CINTED- } \\
\text { UFRGS }\end{array}$ & $\begin{array}{l}\text { Desenvolvendo o Raciocínio } \\
\text { Lógico e o Pensamento } \\
\text { Computacional: Experiências no } \\
\text { Contexto do Projeto Logicando }\end{array}$ \\
\hline $\begin{array}{l}\text { TIC } \\
\text { RACIOCINÍO } \\
\text { LÓGICO }\end{array}$ & 2005 & $\begin{array}{l}\text { Prieto, Lilian } \\
\text { Medianeira; } \\
\text { Trevisan, Maria do } \\
\text { Carmo Barbosa; } \\
\text { Danesi, Maria } \\
\text { Isabel; } \\
\text { Falkembach, Gilse } \\
\text { A. Morgental }\end{array}$ & $\begin{array}{l}\text { CINTED- } \\
\text { UFRGS }\end{array}$ & $\begin{array}{l}\text { Uso das Tecnologias em } \\
\text { Atividades Didáticas nas Séries } \\
\text { Iniciais }\end{array}$ \\
\hline $\begin{array}{l}\text { TIC } \\
\text { RACIOCINÍO } \\
\text { LÓGICO }\end{array}$ & 2015 & $\begin{array}{l}\text { Batista, } \quad \text { Esteic } \\
\text { Janaina S.; } \\
\text { Jr; Amaury A. A. } \\
\text { Castro; } \\
\text { Bogarim, Cintia } \\
\text { Adriana C.; } \\
\text { Larrea, Andreia A. }\end{array}$ & $\begin{array}{l}\text { CBIE- } \\
\text { LACLO } \\
\text { (Anais do } \\
\text { XXI } \\
\text { Workshop } \\
\text { de } \\
\text { Informática } \\
\text { na Escola) }\end{array}$ & $\begin{array}{l}\text { Utilizando o Scratch como } \\
\text { ferramenta de apoio para } \\
\text { desenvolver o raciocínio lógico } \\
\text { das crianças do ensino básico } \\
\text { de uma forma multidisciplinar }\end{array}$ \\
\hline
\end{tabular}




\begin{tabular}{|l|l|l|l|l|}
\hline & & & \\
\hline $\begin{array}{l}\text { Raciocínio } \\
\text { Lógico, Objetos } \\
\text { de } \\
\begin{array}{l}\text { Aprendizagem e } \\
\text { a TIC }\end{array}\end{array}$ & 2007 & $\begin{array}{l}\text { Scolari, Angélica } \\
\text { Taschetto; } \\
\text { Bernardi, Giliane; } \\
\text { Cordenonsi, Andre } \\
\text { Zanki }\end{array}$ & $\begin{array}{l}\text { Revista } \\
\text { Renote - }-\begin{array}{l}\text { Rio Grande } \\
\text { do Sul }\end{array}\end{array}$ & $\begin{array}{l}\text { O desenvolvimento do } \\
\text { Raciocínio Lógico através de } \\
\text { Objetos de Aprendizagem }\end{array}$ \\
\hline $\begin{array}{l}\text { Matemática e o } \\
\text { uso das TIC }\end{array}$ & 2015 & $\begin{array}{l}\text { Souza, Daiane de de } \\
\text { Oliveira }\end{array}$ & $\begin{array}{l}\text { LUME - } \\
\text { Repositório } \\
\text { Digital - } \\
\text { UFRGS }\end{array}$ & $\begin{array}{l}\text { Ensino de Matemática com o das TIC } \\
\text { Uso dich }\end{array}$ \\
\hline
\end{tabular}

Fonte: Elaborado pelo autor (2021)

A partir da seleção dos 36 textos, foi possível a realização de uma análise aprofundada dos 12 selecionados e, na sequência, serão apresentados os principais achados e contribuições de 6 destes na pesquisa.

\subsection{Descrição dos trabalhos selecionados}

Para iniciar a apresentação dos trabalhos selecionados, elencamos a pesquisa de pós-doutorado de Patrícia Margarida Farias Coelho, da Universidade Pontifícia Católica de São Paulo (2012), que traz uma investigação com o tema "Os Nativos Digitais e as Competências Tecnológicas demostrando as habilidades das crianças e adolescentes nascidos após o ano de 1980 e a importância do uso de dispositivos móveis e games educacionais para incentivar a aprendizagem dos conteúdos nas escolas". (COELHO, 2012).

A autora relata a importância da escola e dos docentes estarem atualizados com os novos recursos digitais para atender e proporcionar um ambiente colaborativo aos educandos dessa nova geração tecnológica, já que os métodos tradicionais devem ser atualizados e trabalhados envolvendo a tecnologia para despertar o interesse dos educandos e proporcionar seu desenvolvimento a partir da resolução de problemas, investigação e pesquisas.

Coelho (2012) cita ainda, dois vídeos apresentados por crianças realizando propaganda de uma determinada televisão, suas vantagens em relação a outras televisões fabricadas por outras empresas e a evolução da internet na vida desses adolescentes que produzem vídeos, propagandas, dentre outros e postam no Youtube sem suporte de um adulto. Segundo a autora, acredita-se que as crianças não tiveram ajuda para elaboração e postagem dos vídeos, pois pesquisou e não 
encontrou informações sobre sua elaboração. Essa nova geração possui independência quanto à utilização dos recursos digitais e por outro lado uma dependência da utilização destes em suas tarefas diárias. $\mathrm{O}$ uso dos recursos digitais, segundo a autora, pode favorecer o ensino e aprendizagem dos educandos quando o docente explora e direciona os recursos tecnológicos em descobertas e experimentações envolvendo os conteúdos e propiciando o prazer da interação dos educandos com o meio que está habituado a dialogar e interagir. Os nativos digitais, como são chamados pela autora, não tiveram aulas de informática, mas possuem facilidade em descobrir os caminhos para resolução dos problemas sem medo de cometer erros, diferentemente das resoluções de atividades em sala de aula, onde os educandos sentem-se inseguros quando encontram algo diferente do que lecionado pelo docente.

A autora cita as transformações que vêm ocorrendo no meio educacional quanto à implantação das novas tecnologias nas escolas a partir do apoio do governo federal com investimentos em tablets e computadores buscando uma transformação do ambiente tradicional escolar. Essa transformação educacional possibilita aulas interdisciplinares que envolvem a lógica da comunicação e informação, possibilitando ao docente uma nova metodologia de ensinar, interagir e discutir os conteúdos com seus educandos tornando-se mais próximo de seu público.

Enfim, a autora considera que a utilização dos recursos digitais possibilita uma transformação na forma de ensino e aprendizagem, possibilitando o educando desenvolver suas habilidades na construção de seu conhecimento. Relata ainda, que essa transformação tecnológica acontece no mundo educacional e que a Educação deverá se adequar pedagógica e tecnologicamente para atender aos anseios da sociedade.

O segundo texto elencado é "Desenvolvendo o Raciocínio Lógico e o Pensamento Computacional: Experiências no Contexto do Projeto Logicando" (KOLOGESKI, 2016), dos autores Anelise Lemke Kologeski, mestre em Microeletrônica UFRGS; Camille Grings Silva, bacharelando em Sistema da Informação; Débora Nice Ferrari Barbosa, doutora em Ciências da Computação UFRGS; Rodrigo Reis Mattos, bacharelando em Sistema da Informação e Sandra Teresinha Miorelli, mestre em Ciências da Computação PUC-RS. O referido texto 
relata um projeto desenvolvido a fim de aprimorar o ensino e a aprendizagem do raciocínio lógico utilizando as tecnologias da informação e comunicação nos anos finais do Ensino Fundamental, abrangendo a participação de docentes das escolas em Novo Hamburgo, Rio Grande do Sul, estudantes e docentes da Universidade Feevale, do Rio Grande do Sul. O interesse na realização deste projeto desencadeou a partir dos baixos índices apresentados pelos educandos das referidas escolas na Avaliação Nacional do Rendimento Escola, mais conhecida como Prova Brasil.

Tendo em vista as taxas de rendimentos insatisfatórios referentes ao aprendizado sobre resolução de problemas, apresentados a partir do Índice de Desenvolvimento da Educação Básica - IDEB, no ano de 2013, foi proposta a criação do projeto "Ensinando Lógica com as Tecnologias da Informação", com o objetivo de despertar o interesse pelos conteúdos e melhorar o desempenho dos educandos quanto ao raciocínio lógico em diversas áreas, pois, segundo os autores da pesquisa, apenas $13 \%$ dos 485 avaliados obtiveram bom desempenho nessa competência, ou seja, aproximadamente 63 educandos obtiveram bom desenvolvimento.

$O$ uso das tecnologias pelos autores, foi escolhido por se tratar de uma ferramenta de interesse entre os educandos do Ensino Fundamental. A intenção do projeto é utilizar as ferramentas tecnológica de forma atrativa e participativa por parte dos educandos, em que possam ser construtores do seu conhecimento com a prática e não meros participantes passivos como acontece em muitas unidades escolares, onde o docente utiliza as ferramentas tecnológicas para apresentação de conteúdo, pesquisas e realização de trabalhos, inibindo ao educandos a descoberta e construção do seu saber através do raciocínio e resolução de problemas com a investigação e utilização dos recursos digitais.

Tal projeto apresenta a proposta de qualificação dos docentes com relação ao uso das ferramentas tecnológicas para expandir a utilização da mesma e melhorar seus índices quanto à competência relacionada à resolução de problemas e raciocínio lógico, formando e capacitando cidadãos para o mundo com a qualificação e conhecimento necessários das ciências tecnológicas e possibilitando o interesse destes por essa área desde o Ensino Fundamental. Dentro do projeto de formação/capacitação dos docentes, foi realizada uma programação de atividades a serem praticadas nas escolas com os educandos, ou seja, foi elaborado um 
cronograma com a previsão e aplicação das oficinas nos laboratórios de informática envolvendo lógica e programação.

Para avaliar o desempenho dos educandos participantes, foi proposto um préteste antes das atividades no laboratório e outra após as práticas laboratoriais almejando avaliar o desempenho dos educandos e seus rendimentos quanto ao conteúdo. Ao final de cada ano, o projeto pretende desenvolver uma Olimpíada de Lógica para avaliar e incentivar as escolas participantes na obtenção dos resultados das experiências do projeto Logicando.

Como resultados parciais do projeto, foi apresentada uma comparação entre as atividades pré-testes e pós-testes, demonstrando melhorias na aprendizagem das três oficinas desenvolvidas, destacando o melhor desenvolvimento para aquela que envolvia Lógica de programação com Games. Tal atividade despertava maior interesse dos educandos e facilidades em seu manuseio, pois a maioria dispõe de aparelho para competição que desencadeou entre os participantes.

Segundo os autores, algumas escolas tiveram a oportunidade de utilizar o laboratório da Universidade para aplicar suas oficinas. Esse fato possibilitou aos educandos um contato direto com a vida acadêmica que terão no futuro e os motivou a aprofundar seus estudos na área da tecnologia com conhecimento e rendimentos satisfatórios quanto ao uso do raciocínio lógico e sua aplicação.

Esse projeto objetivou aprimorar a coleta de dados nos pré e pós-testes, informatizando tais procedimentos e melhorando outros mecanismos utilizados, o que facilitou e resolveu as dificuldades encontradas no primeiro semestre de 2016, quando foi desenvolvido.

Já, o terceiro texto elencado nesta revisão, identificado como "Uso das tecnologias digitais em atividades didáticas nas séries iniciais", (PRIETO et al, 2005) desenvolvidos por Lilian Medianeira Prieto, Maria do Carmo Barbosa Trevisan, Maria Isabel Danesi e Gilse A. Morgental Falkembch, pesquisadores da Universidade Federal do Rio Grande do Sul, relata o interesse dos educandos, desde as séries iniciais, do Ensino Fundamental, pela utilização de jogos e aplicativos por este público nas suas atividades, priorizando o raciocínio lógico e a memorização até os dos anos finais. 
Os autores demonstram a importância da transformação na educação com as propostas pedagógicas inovadoras através da utilização dos computadores para facilitar o ensino e aprendizagem e despertar o interesse dos educandos nas descobertas e investigações realizadas. Eles descrevem a importância dos docentes e profissionais da educação na busca pelo desenvolvimento de softwares educacionais de acordo com a vida, cotidiano e realidade dos educandos por regiões, já que as empresas que elaboram os softwares não conseguem atender as realidades encontradas em sala de aula, reduzindo assim, o aproveitamento de determinados softwares educacionais. A qualidade de um software depende de um conjunto de profissionais, tais como, da área da psicologia, da educação e da área tecnológica.

Relatam ainda que a presença das tecnologias digitais na educação, através de softwares, jogos e tutoriais possibilitam uma motivação e interesse dos docentes desde que estes estejam capacitados e preparados para executar tais atividades em suas práticas pedagógicas, atingindo com êxito os objetivos almejados. Outro fato mencionado no texto e de extrema importância no processo de ensino e aprendizagem é o "feedback" oferecido pelos softwares educacionais, oportunizando os educandos a aprenderem com os erros e reverem as questões que obtiveram dificuldades na realização de suas tarefas ou construções.

Os autores descrevem como é o desenvolvimento humano e a aprendizagem dos educandos a partir da teoria dos estágios de Piaget, em que o mesmo considera que o educando passa por diversas fases na sua aprendizagem, facilitando sua compreensão se executadas nas faixas etárias adequadas. Pode-se destacar o terceiro estágio que ocorre entre sete e doze anos da criança, como período favorável para explorar o raciocínio lógico com jogos e materiais concretos que contribuem com o desenvolvimento das habilidades operatórias. Nesse sentido, os autores apontam que Vygotski contradiz a teoria de Piaget, expondo que o indivíduo se desenvolve adquirindo conhecimento sozinho ou no relacionamento com outras pessoas, ou seja, o desenvolvimento do educando será construído a partir das suas relações com o homem e o meio ambiente, tendo a participação dos mediadores.

Os autores apontam ainda a importância do estímulo à leitura e a escrita das crianças, fatos estes que facilitam o desenvolvimento nas fases escolares posteriores, tais como a compreensão da ortografia e a interpretação nas resoluções de 
problemas. Relatam também a contribuição que as multimídias e as atividades digitais oferecem aos educandos, despertando interesse devido à sua apresentação, layout, cores e movimentos visíveis, entre outras. Para o sucesso na aplicação das mídias digitais, os autores alertam para o cuidado na seleção de materiais e na verificação dos mesmos, observando o comprometimento do ensino e aprendizagem que estes podem oferecer aos educandos.

Nesse trabalho, os autores desenvolveram a aplicação de multimídias para pré-escola e as séries iniciais da educação básica, usando o sistema de autoria Toolbook, que é um software que utiliza objetos e é manipulado por um script. Uma de suas facilidades é que não se exige conhecimentos de programação para manipular e executar tarefas com os educandos. O software permite 0 desenvolvimento do raciocínio lógico e a memorização nas relações dos nomes com as figuras. Enfim, esse software e outros softwares educacionais podem contribuir no ensino e aprendizagem dos educandos, uma vez que possibilitam a visualização, a investigação e o prazer de executar as tarefas. Como afirmam os autores, dessa forma os educandos constroem seu próprio conhecimento, no seu ritmo e de forma agradável.

O texto "Utilizando o Scratch como ferramenta de apoio para desenvolver o raciocínio lógico das crianças do ensino básico de uma forma multidisciplinar" (BATISTA et al, 2015) de autoria de Esteic Janaina S. Batista, Amaury A. Castro Jr., Cintia Adriana C. Bogarim e Andreia A. Larrea, foi desenvolvido por pesquisadores da Universidade Federal de Mato Grosso do Sul, tendo como objetivos a preparação de docentes para utilizar o Scratch como recurso nas aulas de diferentes disciplinas, tornando as aulas atrativas e descontraídas, além de elevar o desempenho dos educandos nas avaliações da Olimpíadas Brasileiras de Robótica (OBR) e nas Olimpíadas Brasileiras de Informática (OBBI).

A Universidade Federal de Mato Grosso do Sul, segundo os autores, oferece várias oficinas envolvendo tecnologias, principalmente com o Scratch, com o objetivo de estimular e apoiar o ensino multidisciplinar envolvendo os recursos tecnológicos, o desenvolvimento de projetos de robótica e a elaboração de objetos de aprendizagem pelos docentes envolvidos nos projetos da Universidade. Essa preparação dos docentes visa explorar o interesse dos educandos pelas ciências 
tecnológicas e despertar futuras vocações que poderão surgir no desenvolvimento das tarefas, pois os educandos são incentivados e estimulados a usar a criatividade na elaboração e resolução das tarefas propostas nas oficinas desde o Ensino Fundamental.

Esse programa da Universidade pretende expandir a formação dos profissionais da educação, dos educandos e de outros membros da sociedade que tenham interesse pela utilização das tecnologias com recursos educacionais, principalmente, na área de programação do ensino básico para melhorar o raciocínio lógico matemático das crianças.

A pesquisa apresenta ainda que o Estado do Mato Groso do Sul vem se destacando na participação das OBR e nas OBI, principalmente, na cidade de Ponta Porã, onde ocorrem os projetos realizados pelo grupo denominado "Nerds da Fronteira" que vêm incentivando a participação das escolas e dos educandos nos projetos.

Como estratégia para melhorar o desenvolvimento do raciocínio lógico dos educandos, a Secretaria de Educação de Mato Grosso do Sul (MS) criou a disciplina de Raciocínio Lógico no Ensino Fundamental e no Ensino Médio a fim de desenvolver o pensamento dos educandos nas resoluções de qualquer problema a partir de sua estruturação.

Os componentes curriculares norteiam como a disciplina de Raciocínio Lógico deverá ser trabalhada nos anos iniciais da educação básica, orienta os docentes a planejar suas aulas com atividades interessantes e desafiadoras, estimulando 0 desenvolvimento da resolução de problemas com a utilização de softwares, jogos, dentre outros.

Os autores expõem os conteúdos que compõem a matriz curricular da disciplina de Raciocínio Lógico e a utilização do Scratch devido à multidisciplinaridade que o software oferece com suas ferramentas. O Scratch permite criar jogos, animações e histórias, além de incentivar a programação desde a educação básica, devido aos recursos que são oferecidos, tais como: som e imagem, a visualização dos resultados das suas construções, dentre outros detalhes que chamam a atenção dos educandos na prática. 
A pesquisa sobre "O desenvolvimento do raciocínio lógico através de objetos de aprendizagem" (SCOLARI, BERNARDI, CORDENONSI, 2007), realizada por Angélica Taschetto Scolari e Giliane Bernardi, ambos do Centro Universitário Franciscano, e por Andre Zanki Cordenonsi da Universidade Federal de Santa Maria, no Rio Grande do Sul, busca auxiliar o ensino e aprendizagem do raciocínio lógico dos educandos com uso dos recursos tecnológicos, nesse caso, através de objetos de aprendizagens apoiados na padronização do projeto Rived.

Semelhante ao trabalho anterior, este também considera importante a prática e o desenvolvimento do raciocínio lógico desde a infância do educando, facilitando o ensino em sala de aula e fora da mesma.

Os autores trazem algumas definições e dentre elas esclarecem que o estudo do raciocínio lógico possibilita ao educando chegar a conclusões exatas, distinguindo o certo do errado, possibilitando e proporcionando um melhor desenvolvimento nos estudos e desafios futuros.

Assim como o trabalho anterior, mencionam a teoria de Piaget (1975) e seus estágios, priorizando a importância do desenvolvimento lógico na faixa de 12 a 15 anos e a exploração do raciocínio nessa faixa etária.

Para os autores, a utilização de objetos de aprendizagem no ensino do raciocínio lógico facilitará o desenvolvimento do educando em outras fases de sua vida, além de proporcionar um ambiente educacional participativo e interessante para eles.

Relatam ainda que o objetivo dos objetos de aprendizagem é facilitar 0 cotidiano dos docentes com atividades de fácil acesso e aplicabilidade, pois os objetos de aprendizagem aparecem com um roteiro para guiar o docente em sala de aula na aplicação das atividades envolvendo os recursos tecnológicos. Essas tarefas despertam interesse dos educandos devido aos desafios propostos com animações, cores, som, dentre outros mecanismos de interesse dos educandos. Outro fato que é explorado é a investigação a partir de desafios instigando a curiosidade dos educandos em resolvê-los, facilitando o trabalho do docente, a comunicação e interação entre docente/educando. $O$ texto contém informações referentes ao projeto Rived, bem como sua criação e desenvolvimento. Menciona acordo entre Brasil, EUA, Peru e Venezuela até 2003 na execução do projeto que a partir de 2004, no Brasil, a 
Secretaria de Educação a Distância (SEED) transferiu para as Universidades, mudando o nome para Fábrica Virtual.

Os objetos de aprendizagem do Rived buscam relacionar a mídia com os conceitos de forma interessante, facilitando a resolução de problemas.

Por fim, os autores apresentam, de forma sucinta, quatro objetos de aprendizagem desenvolvidos para estimular e incentivar o desenvolvimento do raciocínio lógico e instigar a criatividade e a investigação nos educandos.

A partir da aplicação dos objetos de aprendizagem, os autores esperam atingir um desenvolvimento do raciocínio lógico dos educandos, ou seja, que estes tenham mais habilidades e facilidades no raciocínio e resolução de problemas e nas interpretações dos mesmos.

O sexto texto selecionado foi de Daiane de Oliveira de Souza, do Curso de Especialização em Mídias na Educação, da Universidade Federal do Rio Grande do Sul (2015) com o tema "Ensino de Matemática com o Uso das TIC". (SOUZA, 2015).

A autora relata a importância da elaboração das tarefas para os educandos de forma interessante para que possam executar as atividades com entusiasmo. Relata, na sua abordagem teórica, que o educando não esquece o conhecimento adquirido a partir dos recursos tecnológicos, pois aprendem de forma instigante. Enquanto, de outra forma, metódica, os resultados nem sempre são satisfatórios, devido à ausência de atrativo pelos conteúdos ou pela transmissão do conhecimento.

Relata ainda, um pouco sobre o software Hot Potatoes e a finalidade de suas ferramentas para trabalhar com os educandos, que possibilita elaboração de diversas tarefas diversificas, como cruzadinhas, explorar conceitos, frases ou textos, dentre outras. Corrobora também com informações sobre o software Geogebra que permite a criação de figuras, gráficos, cálculos, dentre outros e permite o educando visualizar suas construções e seus resultados.

Esclarece que os docentes devem renovar suas concepções de como preparar e lecionar suas aulas, pois o mundo está em transformação e a matemática precisa acompanhar tais mudanças. Sugere como iniciativa a atualização com as práticas tecnológicas nos conteúdos matemáticos. 
Além disso, informou que, mesmo com o conhecimento matemático adquirido pelos educandos, foi possível estimular o interesse e o aprendizado a partir das tecnologias durante as atividades propostas. Ressaltou também sobre a importância da utilização do Tangram, Hot Potatoes e o Geogebra nas aulas de matemática para alcançar resultados positivos no ensino e aprendizagem instigados pela curiosidade dessas ferramentas.

Concluiu afirmando que seu objetivo foi alcançado, uma vez que a aplicação das tarefas no laboratório de informática proporcionou uma aprendizagem para vida dos educandos, diferentes das aulas retóricas de matemática. Após a análise das pesquisas apresentadas, observa-se a importância dos recursos digitais no ensino e aprendizagem do raciocínio lógico. Percebe-se ainda a necessidade de atualização dos métodos tradicionais de ensino para atender o interesse dos educandos pelas tecnologias e a formação tecnológica destes para o convívio na sociedade digital que se vivencia.

Durante análise e reflexão destas pesquisas, identificou-se as contribuições que os recursos tecnológicos oferecem aos educandos nas tarefas propostas. Essa comunicação imediata contribui com o ensino e a aprendizagem, já que os educandos conseguem identificar os erros e acertos e, muitas vezes, conseguem obter êxito na construção do conhecimento a partir da análise dos próprios erros.

Os autores destacam que a formação e capacitação tecnológica dos docentes contribuem com o desenvolvimento dos educandos, pois essa formação permite a eles selecionar materiais relevantes no processo de ensino e aprendizagem de acordo com os conteúdos trabalhados, inserindo os recursos digitais em sua prática. No Quadro 7 que segue, será possível notar as contribuições dos textos selecionados:

Quadro 7 - Contribuições dos trabalhos selecionados

\begin{tabular}{|c|c|c|c|}
\hline Título & Ano & Autores & Contribuições \\
\hline $\begin{array}{l}\text { Os Nativos Digitais e as } \\
\text { Competências Tecnológicas } \\
\text { demostrando as habilidades } \\
\text { das crianças e adolescentes } \\
\text { nascidos após o ano de } 1980 \\
\text { e a importância do uso de }\end{array}$ & 2012 & COELHO & $\begin{array}{l}\text { A sua colaboração com a } \\
\text { pesquisa surge a partir da } \\
\text { conclusão que os recursos } \\
\text { tecnológicos despertam } \\
\text { interesse dos educandos, } \\
\text { pois são nativos de uma }\end{array}$ \\
\hline
\end{tabular}




\begin{tabular}{|c|c|c|c|}
\hline $\begin{array}{l}\text { dispositivos móveis e games } \\
\text { educacionais para incentivar } \\
\text { a aprendizagem dos } \\
\text { conteúdos nas escolas }\end{array}$ & & & $\begin{array}{l}\text { geração dependente dos } \\
\text { meios digitais. }\end{array}$ \\
\hline $\begin{array}{l}\text { Desenvolvendo o Raciocínio } \\
\text { Lógico e o Pensamento } \\
\text { Computacional: } \\
\text { Experiências no Contexto do } \\
\text { Projeto Logicando }\end{array}$ & 2016 & $\begin{array}{l}\text { KOLOGESKI, } \\
\text { SILVA, } \\
\text { BARBOSA, } \\
\text { MATTOS, } \\
\text { MIORELLI }\end{array}$ & $\begin{array}{l}\text { A contribuiu com a } \\
\text { pesquisa, pois apresenta } \\
\text { objetivos semelhantes } \\
\text { quanto à busca por } \\
\text { melhores resultados nas } \\
\text { avaliações, como Prova } \\
\text { Brasil }\end{array}$ \\
\hline $\begin{array}{l}\text { Uso das tecnologias digitais } \\
\text { em atividades didáticas nas } \\
\text { séries iniciais", (PRIETO et } \\
\text { al, 2005) }\end{array}$ & 2005 & $\begin{array}{l}\text { PRIETO } \\
\text { TREVISAN } \\
\text { DANESI } \\
\text { FALKEMBACH }\end{array}$ & $\begin{array}{l}\text { O texto deixou como } \\
\text { contribuição alguns } \\
\text { cuidados ao preparar uma } \\
\text { aula com recursos digitais, } \\
\text { tais como utilizar temas } \\
\text { dentro da realidade dos } \\
\text { educandos, ficar atento à } \\
\text { qualidade dos materiais } \\
\text { disponibilizados na internet } \\
\text { e observar o feedback das } \\
\text { tarefas. }\end{array}$ \\
\hline $\begin{array}{l}\text { Utilizando o Scratch como } \\
\text { ferramenta de apoio para } \\
\text { desenvolver o raciocínio } \\
\text { lógico das crianças do } \\
\text { ensino básico de uma forma } \\
\text { multidisciplinar }\end{array}$ & 2015 & $\begin{array}{l}\text { BATISTA; } \\
\text { JR; } \\
\text { BOGARIM; } \\
\text { LARREA. }\end{array}$ & $\begin{array}{l}\text { Essa pesquisa também } \\
\text { busca melhorias nos } \\
\text { rendimentos dos educandos } \\
\text { nas avaliações externas. } \\
\text { Apresentam alguns } \\
\text { recursos tecnológicos que } \\
\text { oferecem como som, } \\
\text { imagem, a visualização dos } \\
\text { resultados das suas } \\
\text { construções viabilizando o } \\
\text { aprendizado. }\end{array}$ \\
\hline $\begin{array}{l}\text { O desenvolvimento do } \\
\text { raciocínio lógico através de } \\
\text { objetos de aprendizagem }\end{array}$ & 2007 & $\begin{array}{l}\text { SCOLARI, } \\
\text { BERNARDI, } \\
\text { CORDENONSI }\end{array}$ & $\begin{array}{l}\text { Contribuíram apresentando } \\
\text { a importância dos Objetos }\end{array}$ \\
\hline
\end{tabular}




\begin{tabular}{|c|c|c|c|}
\hline & & & $\begin{array}{l}\text { de Aprendizagens } \\
\text { envolvendo os recursos } \\
\text { digitais no ensino do } \\
\text { Raciocínio Lógico. }\end{array}$ \\
\hline $\begin{array}{l}\text { Ensino de Matemática com o } \\
\text { Uso das TIC }\end{array}$ & 2015 & SOUZA & $\begin{array}{l}\text { Contribui demonstrando a } \\
\text { finalidade das ferramentas } \\
\text { do Hot Potatoes e os pontos } \\
\text { positivos que sua pesquisa } \\
\text { observou utilizando o os } \\
\text { recursos digitais no } \\
\text { laboratório. }\end{array}$ \\
\hline
\end{tabular}

Fonte: Elaborado pelo autor (2021)

A partir do quadro 7 é possível observar as contribuições que os autores deixaram para nossa pesquisa referente ao meio educacional que os educandos estão nascendo e crescendo, ou seja, desde crianças estão em contato com os recursos tecnológicos. Por isso, os docentes e a escola devem continuar contribuindo para desenvolver e despertar o interesse pelos conteúdos, utilizando as ferramentas digitais disponíveis nos estabelecimentos de ensino e, assim, despertando o interesse e curiosidade por novas descobertas.

Verifica-se a utilização dos recursos tecnológicos em outros Estados com o objetivo de melhorar os índices de rendimento na Prova Brasil e em outras avaliações, demonstrando pontos positivos quanto ao interesse e rendimentos dos educandos. Também é possível notar a importância dos softwares e suas ferramentas, como o Hot Potatoes, Geogebra, dentre outros, a fim de despertar interesse e proporcionar um ambiente instigante para o educando com atividades preparadas de acordo com a sua realidade.

No próximo capítulo, será abordada a metodologia para analisar os dados e a produção de significados dessa pesquisa. 


\section{4 - METODOLOGIA}

Após apresentação da fundamentação teórica e a revisão de literatura para embasar essa pesquisa, iniciamos a descrição da metodologia a ser utilizada na pesquisa, apresentando argumentos referentes a escolha do software, local e o público da pesquisa, como será o desenvolvimento e a execução das tarefas e coleta e análise de dados dessa pesquisa.

\section{1 - Classificação da pesquisa}

A classificação de uma pesquisa corrobora com andamento da análise dos dados a partir da definição das características, objetivos e desenvolvimento e execução da mesma. A metodologia de pesquisa utilizada na investigação será abordagem qualitativa. Segundo Bogdan e Biklen (1994), a investigação com a visão qualitativa é estabelecida a partir de pressupostos, mas nem sempre todos estarão presentes em uma pesquisa. Segundo os autores, tem-se as seguintes características:

$\mathrm{Na}$ investigação qualitativa a fonte direta de dados é o ambiente natural, constituindo o investigador o instrumento principal.

A investigação qualitativa é descritiva.

Os investigadores qualitativos interessam-se mais pelo processo do que simplesmente pelos resultados ou produtos.

Os investigadores qualitativos tendem a analisar os seus dados de forma indutiva.

O significado é de importância vital na abordagem qualitativa. (BOGDAN; BIKLEN, 1994, p.25)

Na primeira característica, o pesquisador deverá analisar o ambiente onde está sendo desenvolvida a pesquisa para conhecer todo o contexto e os detalhes do seu campo visando a uma boa análise dos resultados. Esta é uma característica que foi utilizada nessa pesquisa, pois serão desenvolvidas tarefas envolvendo multiplicação no Conjunto dos Números Naturais para os educandos do Ensino Fundamental II que estimulem o desenvolvimento do Raciocínio Lógico Matemático. Os educandos envolvidos no estudo apresentam dificuldades em sala de aula nos cálculos que envolve Multiplicação (Tabuada) que os impossibilita de desenvolver o raciocínio lógico e apresentam interesses em aulas envolvendo recursos tecnológicos. Nesse caso, no laboratório de informática da escola, uma vez que muitos não possuem 
celular ou acesso à internet em suas residências devido à dificuldade de instalação e fornecimento de sinal de internet com a distância das casas, ou seja, por ser uma zona rural.

$\mathrm{Na}$ obtenção de dados durante a execução das tarefas, em que foram obtidas informações da fala, escrita e imagens dos educandos para registro descritivo e análise da investigação, a resposta destes dados foi enriquecida com os detalhes retirados das interações do grupo de WhatsApp.

Analisou-se o impacto que a utilização dos recursos tecnológicos nas tarefas resultaria nos educandos, principalmente, quanto ao interesse e estímulo em desenvolvê-las, proporcionando um novo olhar do docente. O comportamento dos educandos no grupo seria diferente daquele que estava acostumado em sala de aula e o diálogo entre educando/docente com a mediação de informações foi amplamente facilitado.

De forma indutiva, verificou-se as informações recolhidas durante a investigação, tendo fatos e questões que apresentaram destaque, ou seja, as informações mais relevantes para pesquisa. Na última característica, ocorreu a construção da conclusão dos resultados a partir do diálogo entre o investigador e os respectivos sujeitos da pesquisa, os educandos, pois a sua diversidade de opiniões contribuiu com essa fase da pesquisa.

Observou-se nessa investigação qualitativa o processo de ensino e aprendizagem que foi construído pelos educandos durante a atividade, ou seja, os efeitos de uma tarefa com recursos tecnológicos provocaria no educando, diferente de uma investigação quantitativa, que prioriza resultados numéricos das tarefas.

A partir dessa análise investigativa, pretende-se responder à questão apresentada: como a aplicação de tarefas envolvendo multiplicação no Conjunto dos Números Naturais com o uso das TIC, Whatsapp, podem estimular o desenvolvimento do Raciocínio Lógico Matemático em educandos do Ensino Fundamental?

Para responder a essa pergunta, apresentam-se dois produtos educacionais:

- Sequência de tarefas impressas enviadas para os educandos com ajuda da escola e resolução num período determinado, sendo que nesse período houve a criação de um grupo de Whatsapp para dar suporte e orientar as dúvidas dos 
educandos. As dúvidas foram apresentadas e conduzidas para que os colegas ajudassem a formulação do raciocínio dos demais e, assim, solucionar os problemas.

- Implementação de atividades no software Hot Potatoes para o uso dos professores quando ocorrer o retorno das atividades presenciais nas escolas. Essa era a proposta inicial da pesquisa, avaliar o desempenho dos educandos no laboratório de informática com atividades envolvendo raciocínio lógico e as ferramentas digitais. Entretanto, devido à Pandemia do Covid-19, essas tarefas foram adaptadas para serem utilizadas futuramente.

\section{2 - Objetivos e procedimentos}

Os objetivos dessa pesquisa são descritivos e exploratórios. Descritivo devido às argumentações e dúvidas apresentadas dentro do grupo de WhatsApp em conjunto e colaboração com aprendizagem dos outros e exploratória pelo fato da participação e orientação do pesquisador quanto aos conteúdos e ao grupo, tornando assim próximo do problema.

\section{3 - Características da pesquisa}

Nessa pesquisa, foram observadas as interações no grupo de WhatsApp quanto as dúvidas, as explicações e os resultados dessas interações. Também serão levadas em conta as anotações e resoluções dos educandos nos materiais enviados de forma impressa para avaliar a produção de significados ocorrida nas atividades de forma colaborativa.

\subsection{1 - Local da pesquisa}

Inicialmente a pesquisa seria realizada no município de Três Rios, mas, com a Pandemia do Covid - 19, houve a necessidade de alteração do local devido à dificuldade de interação com os educando e docentes da escola. 
A pesquisa foi realizada na Escola 2 e a escolha do local se deu pelo fato do pesquisador lecionar nessa Unidade Escolar, o que facilitou a comunicação e interação com os educandos e direção da escola.

A escola disponibilizou laboratório de informática em funcionamento. Contudo, em virtude da Pandemia da COVID-19, a pesquisa foi adaptada para aplicação das tarefas a partir de envio das tarefas impressas, possibilitando todos os educandos a participarem da pesquisa e as discussões serem realizadas a partir de um grupo de WhatsApp.

\subsection{2 - Público Alvo}

A pesquisa foi desenvolvida em três turmas do $8^{\circ}$ ano de escolaridade do Ensino Fundamental, totalizando 56 educandos. Uma característica peculiar nessas turmas é a dificuldade de acesso à internet devido à localização de suas residências serem na zona rural, ou seja, residem em sítios ou fazendas afastados do centro do distrito.

Com a aplicação das tarefas a partir de material impresso e encaminhamento às residências dos educandos, estes tiveram a oportunidade de desenvolverem as tarefas para serem posteriormente analisadas. Nem todos os educandos puderam participar das discussões no grupo de WhatsApp por causa da precariedade de sinal de internet nas suas residências localizada em sítios ou fazendas, ou seja, zona rural.

Outro fato relevante sobre o público-alvo da pesquisa é o desinteresse pelas aulas, conteúdos e atividades escolares, que são notórias quando analisamos os índices das escolas envolvidas com baixos índices em matemática. Essa proposta visa estimular os educandos pelos conteúdos, pela escola, pelo seu ensino e aprendizagem. Nesse sentido, o WhatsApp pode contribuir com os docentes nas aulas e interações.

Pretende-se, com essa ação, mostrar os benefícios que as interações de um grupo de WhatsApp pode contribuir quanto ao interesse dos educandos pelo conteúdo. 
4.4 - Desenvolvimento e execução das tarefas

Devido à atual situação mundial com a Pandemia Covid-19, as tarefas foram desenvolvidas para serem aplicadas de forma tradicional (impressa) e, com o apoio da escola, foram enviadas para os educandos e trinta dias depois foram recolhidas de forma remota, pois a escola nesse momento de Pandemia está disponibilizando apostilas mensais para os educando, nesse caso os materiais são retirados e devolvidos dentro de um cronograma estipulado.

A proposta inicial era aplicar as tarefas utilizando o software Hot Potatoes no laboratório de informática da escola. Impossibilitada pelo período da Pandemia, foi implementada a sequência de tarefas no software Hot Potatoes para que os docentes possam utilizar em suas aulas após a Pandemia.

O conteúdo abordado envolve a Multiplicação no Conjunto dos Números Naturais, instigando o desenvolvimento do Raciocínio Lógico. Foram criadas dez atividades com nível básico que envolviam o cotidiano dos educandos para facilitar o raciocínio.

Vale ressaltar que, nesse período de Pandemia, a Escola aderiu a utilização do WhatsApp em suas práticas diárias, sendo utilizado nos horários de aula normal da escola. Com esse recurso, os docentes aplicavam os conteúdos, atividades, correções e tiravam dúvidas das apostilas enviadas mensalmente. Cada turma possuía um grupo de WhatsApp com a participação da direção, orientação pedagógica, professores e educandos no auxílio do ensino e aprendizagem.

Assim, a partir do momento que a sequência de tarefas foi enviada aos educandos no início de novembro, foi criado um grupo de WhatsApp com os educandos da turma do $8^{\circ}$ ano, selecionados para a pesquisa, objetivando orientar e acompanhar as discussões referentes às tarefas, bem como coletar dados e informações para a análise da produção de significados.

A sequência de tarefas foi enviada para as residências dos educandos no dia nove de novembro e retornaram para escola no dia oito de dezembro de 2020 . No dia seguinte, o pesquisador teve acesso aos materiais, após separar as tarefas das demais atividades da apostila mensal. 
No momento da execução das tarefas, os educandos puderam utilizar rascunho, lápis, borracha e foram orientados de como deveriam proceder. Observase que, devido à natureza da análise da produção de significados, a intervenção do pesquisador foi a mínima possível, objetivando que os educandos desenvolvessem suas justificações e chegassem as suas conclusões, pois a intervenção do pesquisador poderia influenciar o raciocínio do educando. A observação do pesquisador levou em consideração os fatos mais relevantes, a fim de construir um parecer dos resultados da análise da pesquisa da produção de significados.

\section{5 - Coleta de dados}

Segundo Bogdan e Biklen (1994), a coleta de dados pelo investigador pode ser enriquecida seguindo algumas características utilizadas nessa coleta de dados. A análise do ambiente em que foram propostas as tarefas. Nesse caso, o grupo de WhatsApp, deixando as orientações da finalidade do grupo para evitar mensagem, áudios e conversas aleatórias. Foram obtidas as informações e selecionadas as mais relevantes e que demonstravam impactos para obtenção de resultados.

As tarefas enviadas de forma impressa foram corrigidas para obter os resultados dos educandos participantes utilizando os meios remotos da escola e serem comparados com os números de participantes nos grupos de WhatsApp.

\section{6 - Análise dos dados}

Após o desenvolvimento e aplicação da sequência de tarefas e das discussões no grupo de WhatsApp, foi possível realizar a análise de todo o processo da produção de significados construído durante a execução e, para isso, utilizou-se o Modelo dos Campos Semânticos. Silva (2003) considera importante o seguinte processo na análise:

i) A constituição de objetos - coisas sobre as quais sabemos dizer algo e dizemos - que nos permite observar tantos os novos objetos que estão sendo constituídos quanto os significados produzidos para esses objetos;

ii) A formação de um núcleo: as estipulações locais, as operações e sua lógica;

iii) A produção de conhecimento; 
iv) Os interlocutores;

v) As legitimidades, isto é, o que é legítimo ou não dizer no interior de uma atividade. (SILVA, 2003, p.77).

A partir desse processo, percebe-se que a produção de significados varia de acordo com o público que está sendo investigado. Por isso, há uma preocupação em conhecer o ambiente e o público que vai aplicar a tarefa. Isso permite uma interpretação e análise das atitudes e procedimentos executados pelos participantes.

Para a análise da produção de significados dos educandos participantes da pesquisa, faz-se necessário transcrever e apresentar os diálogos realizados no grupo de WhatsApp juntamente com as atividades desenvolvidas pelos educandos e devolvidas ao pesquisador.

A partir dos dados obtidos, foi possível apresentar e analisar a produção de significados, através do Modelo dos Campos Semânticos. Vale ressaltar que foram considerados os pensamentos expostos pelos educandos, pois cada um pode compreender e buscar caminhos diferentes para representar seu pensamento através de uma justificativa.

\section{7 - Escolha do Software para a implementação da sequência de tarefas}

Antes de iniciar a descrição da escolha do software, ressalta-se que, conforme já justificado anteriormente, houve a necessidade de adaptação na aplicação da pesquisa. Assim, destaca-se que, além das atividades desenvolvidas e enviadas em papel impresso aos educandos com a mediação do Whatsapp, o qual gerou o primeiro Produto Educacional denominado, "Sequência de tarefas para o desenvolvimento do Raciocínio Lógico Matemático com apoio do Whatsapp para o Ensino Fundamental", também foram implementadas no software Hot Potatoes a sequência de tarefas, o qual gerou nosso segundo Produto Educacional denominado, "Recurso Educacional Digital para o Desenvolvimento do Raciocínio Lógico Matemático no Ensino Fundamental".

A escolha do software Hot Potatoes se deve à facilidade no manuseio de suas ferramentas tanto pelo docente quanto pelo educando, permitindo a possibilidade de cativar e envolver a atenção e explorar o raciocínio lógico deles com os conteúdos. A organização da sequência de atividades almeja que os educandos tenham 
conhecimento do seu desenvolvimento a partir das tarefas que despertarão interesse dos mesmos. Souza (2015) salienta que

A ferramenta de autoria Hot Potatoes pode ser utilizada por professores de Matemática para elaborar as aulas atrativas para os alunos. É um software de fácil compreensão. É uma grande oportunidade para os professores de Matemática cativarem seus alunos, pois tem várias alternativas para realizar as atividades com a criatividade no JCloze, JMatch, JQuiz, JMix e o The Masher. (SOUZA, 2015, p. 18)

A proposta foi utilizar o software Hot Potatoes a fim de incentivar o ensino e aprendizagem dos educandos com atividades envolvendo computadores e o software proposto.

Lisboa e Malafaia esclarecem que cada módulo do Hot Potatoes tem uma finalidade e pode ser trabalhado em todas as disciplinas, ou seja, ele é interdisciplinar. Os autores apresentam os módulos do software:

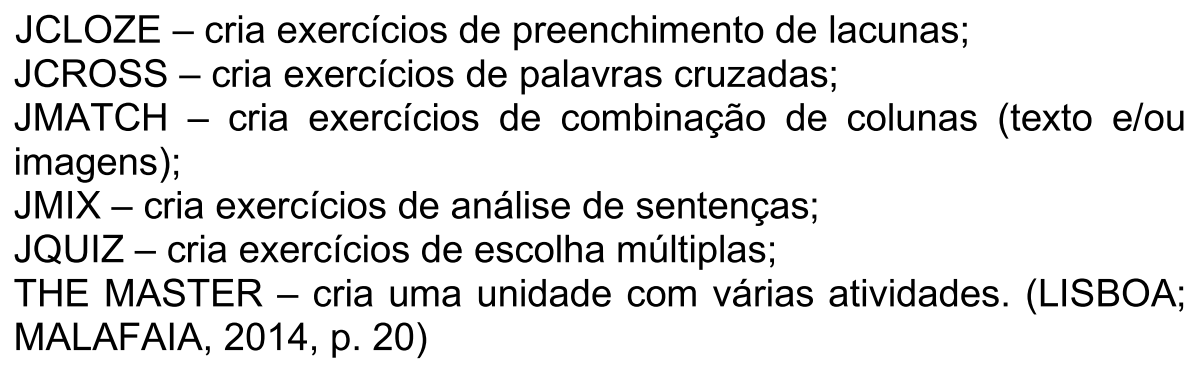

Para facilitar o desenvolvimento de novas tarefas envolvendo os recursos tecnológicos, escolheu-se o Hot Potatoes por estar disponível com gratuidade, facilidade no manuseio e ser um software denominado de Autoria. Destaca-se que o docente não precisa ter conhecimentos de programação para elaborar uma atividade ou avaliação e, ainda, há a possibilidade de interatividade. Outro ponto importante é a interdisciplinaridade, que possibilita o docente executar tarefas de várias disciplinas em revisão dos conteúdos para avaliações, dentre outros trabalhos que podem ser elaborados.

Em relação a software de Autoria, Júnior, Neto e Costa afirmam que,

Os Softwares de Autoria permitem o desenvolvimento da criatividade do professor que trabalha como Autor e permite o desenvolvimento de novas atividades. Este tipo de software permite trabalhar tanto com a manipulação de dados, quanto com a construção do conhecimento através dos recursos oferecidos. Os professores, com esse tipo de software, podem desenvolver suas 
aplicações sem que seja necessário conhecer código de programação. (JUNIOR; NETO; COSTA, 2002 p,.2)

Lisboa e Malafaia apontam algumas características que também culminaram na escolha desse software,

O software Hot Potatoes é executado em plataformas Windows e Linux e pode ser utilizado em ambientes virtuais de aprendizagem, como a plataforma Moodle. O programa não tem custos para os educadores ou organizações públicas sem fins lucrativos. Em hipótese alguma pode ser comercializado. O Hot Potatoes pode ser baixado gratuitamente. (LISBOA; MALAFAIA, 2014, p, 20)

Essas facilidades quanto à usabilidade do software permitem ao docente um trabalho com os educandos na escola. Segundo Rosso e Flores (2017), há outra possibilidade para o docente trabalhar o software com o educando a partir do estímulo e do desafio em manusear o Hot Potatoes, já que "é um recurso em que o educando sente na pele um pouco de como é ser professor, pois ele cria as atividades a serem concluídas e com isso passa a ver o conhecimento de um ângulo diferente". (p.206). Rosso e Flores (2017) afirmam ainda que "o programa é válido na construção do conhecimento de cada um e principalmente na introdução da tecnologia como fator motivador no processo de ensino-aprendizagem". (p.208)

Rosso e Flores (2017) apontam mais algumas vantagens desse software, tais como:

Ao realizar os exercícios do Hot Potatoes, o próprio software manda um feedback, o qual mostra frases de incentivos, tais como "tente outra vez" ou "parabéns". Além disso, ainda é possível personalizar o software com cores de fundo da preferência dos usuários ou frases mais adequadas ao contexto. (p.214)

Esses detalhes fazem diferença na execução das atividades, pois o educando é incentivado e desafiado ao mesmo tempo pela máquina.

Para facilitar o manuseio das ferramentas e aplicabilidade deste software, há vários tutoriais ${ }^{7}$ na internet sobre instalação e construções envolvendo esse recurso tecnológico.

\footnotetext{
${ }^{7}$ https://www.youtube.com/watch?v=gKDM4AbpOVA\&t=53s
} 


\section{5 - PROPOSTA DE TAREFAS}

A elaboração das tarefas aplicada de forma tradicional (impressa) aos educandos foi desenvolvida a partir de assuntos do cotidiano dos educandos. Nessa elaboração, pensou-se em tratar de assuntos que fazem parte da sua rotina, com problemas envolvendo a multiplicação do Conjunto dos Números Naturais com temas referentes à sorvete, time de futebol, dentre outros.

Foram elaboradas dez questões em forma de problemas variando o grau de dificuldade, do básico para avançado, a fim de verificar a capacidade do raciocínio lógico matemático desenvolvido nas habilidades da multiplicação e analisar a produção de significados.

O raciocínio lógico matemático ocorre pelo desenvolvimento dos educandos em realizar os cálculos com rapidez aprimorando a interpretação, comunicação e a resolução de problemas. Ao observar que os educandos das turmas do $8^{a}$ ano apresentavam dificuldades com cálculos de tabuada simples, resolveu-se trabalhar e aplicar a pesquisa com eles objetivando desenvolver o raciocínio lógico matemático e auxiliar o processo de aprendizagem envolvendo a multiplicação com o Conjunto dos Números Naturais. As questões desenvolvidas exigem dos educandos concentração, compreensão lógica e/ou conhecimentos alternativos para solucionar os problemas propostos.

\section{Questão 1:}

Arthur possui 25 bolinhas de gude. Seu irmão Alisson ganhou várias bolinhas de gude na escola. Agora, Alisson possui o triplo de bolinhas de gude de Arthur. Quantas bolinhas de gude Alisson possui?
a) 25
b) 50
c) 75
d) 100

Questão 2:

Numa escola há 35 meninos na Educação Infantil. E a quantidade de meninas é o dobro dos meninos. Quantas meninas tem na Educação Infantil?
a) $\mathbf{4 0}$
b) 50
c) 60
d) $\mathbf{7 0}$ 
Questão 3: Na turma do $5^{\circ}$ Ano de Escolaridade, há 4 tricolor (torcedor do Fluminense). 0 número de flamenguista (torcedor do Flamengo) é o quádruplo da quantidade de tricolores. Quantos flamenguistas tem nessa turma?
a) 16
b) 20
c) 24
d) 28

Questão 4: Uma família foi almoçar no restaurante que estava com a promoção de $R \$ 9,00$ o prato de comida. Essa família é formada por 5 pessoas, quanto gastaram com a alimentação nesse dia no restaurante?
a) $\mathbf{R} \$ \mathbf{4 0 , 0 0}$
b) $R \$ 45,00$
c) $\mathbf{R} \$ \mathbf{5 0 , 0 0}$
d) $\mathbf{R} \$ \mathbf{5 5 , 0 0}$

Questão 5: A sorveteria vende picolé por $R \$ \mathbf{3 , 0 0}$. Quanto gastarei se levar meus 6 sobrinhos na sorveteria e comprar um picolé para cada um sobrinho?
a) $\mathrm{R} \$ 12,00$
b) $R \$ 15,00$
c) $R \$ 18,00$
d) $R \$ 21,00$

Questão 6: 0 ônibus escolar possui 16 lugares do lado direito e a mesma quantidade de acentos no lado esquerdo. Quantos acentos há nesse ônibus?
a) 30
b) 32
c) 34
d) 36

Questão 7: A professora Josiane gasta $\mathbf{R} \$ 7,00$ com passagem para ir trabalhar por dia. Ela trabalha 4 vezes na semana. Quanto ela gasta por semana com passagem?
a) $R \$ 28,00$
b) $R \$ 35,00$
c) $R \$ 42,00$
d) $\mathbf{R} \$ 49,00$

Questão 8: A turma do $5^{\circ}$ Ano de Escolaridade é formada por 28 alunos. Sendo o número de meninas o triplo do número de meninos. Quantas meninas há nessa turma?
a) 14
b) 21
c) 28
d) 35

Questão 9: A loja "Atualize" vende pacote de figurinhas por $\mathbf{R} \$ \mathbf{8 , 0 0}$. Dênis comprou quatro pacotes de figurinhas. Quanto Dênis pagou no caixa da loja?
a) $R \$ 16,00$
b) $R \$ 24,00$
c) $R \$ 32,00$
d) $\mathbf{R} \$ \mathbf{4 0 , 0 0}$ 
Questão 10: Uma sala de aula tem 5 fileiras de carteiras para os alunos sentarem. Sabendo que cada fileira possui 6 carteiras, determine quantas carteiras há nessa sala de aula?
a) 15
b) 20
c) 25
d) 30

No próximo tópico, serão analisados os resultados a partir da aplicação das sequência de tarefas no contexto do ensino remota (tarefas impressas), bem como quanto as discussões ocorridas no grupo de WhatsApp. 


\section{6 - APRESENTAÇÃO E ANÁLISE DOS DADOS}

Esse trabalho de campo se iniciou com a aplicação das tarefas de forma remota, devido à Pandemia referente ao Covid-19. O ensino remoto ocorreu na forma de envio, pela escola, de materiais impressos mensais aos educandos de todas as disciplinas, formando assim uma apostila mensal.

Os dados foram analisados sob a perspectiva do Modelo dos Campos Semânticos de Rômulo Lins, a fim de analisar a produção de significados nas tarefas e ainda, a interação no grupo de WhatsApp, possibilitando a análise da construção coletiva do conhecimento. Historicamente a análise do MCS sempre foi realizada através da ação de educandos em sala de aula e gravações de vídeo, por não haver possibilidade da realização das atividades (sequência de tarefas) que envolvem o desenvolvimento do raciocínio lógico de forma presencial. Nessa pesquisa, a análise ocorrerá a partir da verificação das respostas e anotações dos educandos nos materiais que retornaram e ainda, na análise dos diálogos ocorridos no grupo criado no aplicativo WhatsApp. Tais diálogos, compreendem em textos e estão reproduzidos na forma de print da tela do celular com as referidas análises.

6.1 - Descrição dos resultados das tarefas aplicadas remotamente em impresso

Para execução dessa parte da pesquisa, conta-se com o apoio da equipe da escola CEMP Professora Dezilma Marques de Souza, que enviou o material impresso aos 56 educandos matriculados no $8^{\circ}$ ano do Ensino Fundamental, divididos em três turmas. Esse material da pesquisa foi disponibilizado aos educandos juntamente com o mensal da escola, ensino remoto. Os educandos permaneceram cerca de um mês com o material e, durante esse mês, ocorreu a criação do grupo de WhatsApp para interação dos educandos quanto às questões propostas. Vale ressaltar que nem todos os educandos possuem WhatsApp e acesso à internet diário. Dos 56 que receberam o material impresso, no dia nove de novembro de 2020, apenas 36 participaram do grupo de WhatsApp devido às dificuldades de acesso à rede na zona rural. Esse quantitativo representa $64 \%$ dos educandos envolvidos na pesquisa que poderiam ter participado das discussões no referido aplicativo. 
Após o período de execução das tarefas, foram recolhidos os materiais e contabilizamos 26 devoluções dos que foram enviados, no dia oito de dezembro de 2020. Então, conclui-se que 30 educandos não devolveram os materiais na Unidade Escolar conforme estabelecido. Esse quantitativo corresponde a uma execução de $46 \%$ dos materiais propostos. A sequência de tarefas é composta por dez questões.

A questão 1 da sequência de tarefas envolve Numerais Multiplicativos, conteúdos trabalhados nos anos anteriores. Espera-se nessa questão que o educando tenha o raciocínio lógico de realizar o cálculo utilizando a multiplicação para chegar ao resultado de forma ágil e eficaz, conforme o objetivo do raciocínio lógico.

\section{Questão 1:}

Arthur possui 25 bolinhas de gude. Seu irmão Alisson ganhou várias bolinhas de gude na escola. Agora, Alisson possui o triplo de bolinhas de gude de Arthur. Quantas bolinhas de gude Alisson possui?
a) 25
b) 50
c) 75
d) 100

Observou-se, na análise das resoluções dos educandos nos materiais impressos, que eles têm um conhecimento semelhante ao assunto, pois 15 deles resolveram da mesma forma a questão 1, efetuando a partir do cálculo da multiplicação, conforme ilustrado na imagem 1 :

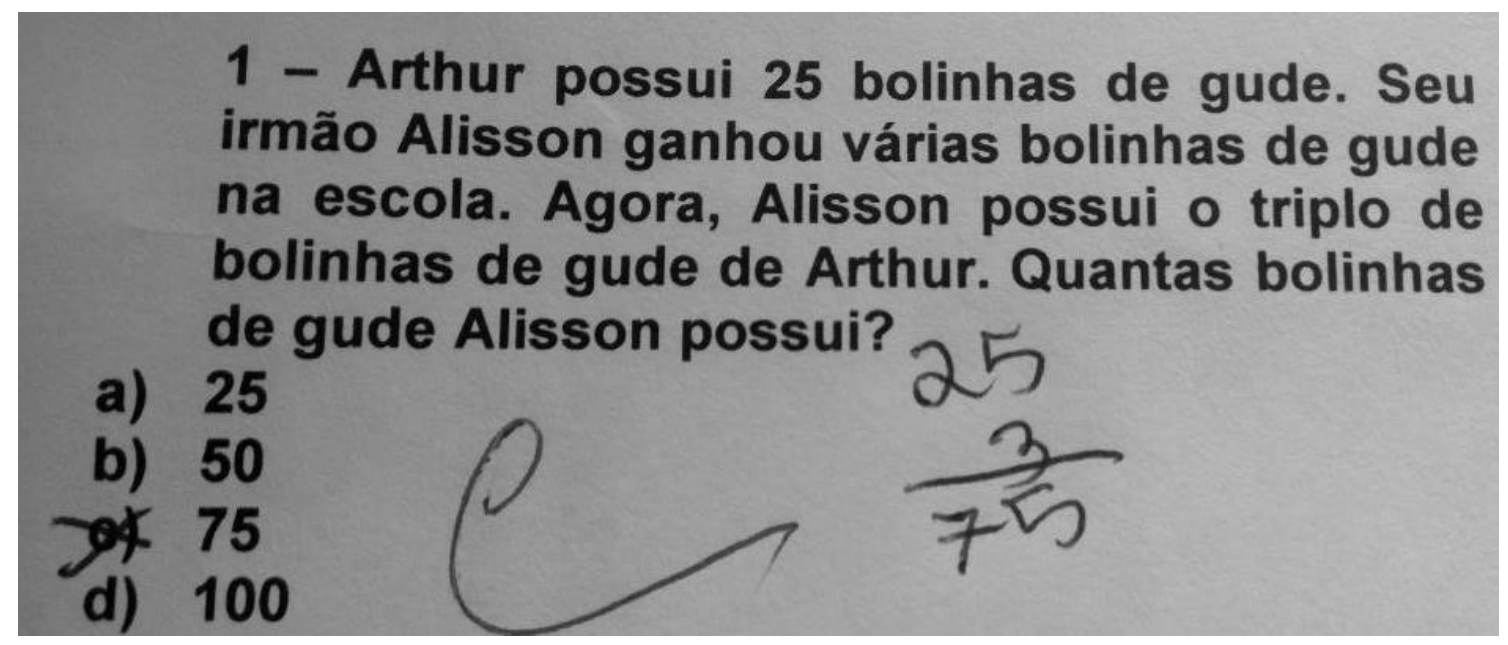

Imagem 1 - Resolução por Multiplicação

Segundo Silva (2003), o MCS mostra que a análise do desencadeamento de um processo para solucionar um determinado problema com utilização de operação (multiplicação, nesse caso) gera a produção de significados, conforme ocorreu nessa questão. Dessa forma, com a prática, o educando alcançará seu raciocínio lógico que é executar os cálculos com agilidade. Nota-se também que 6 educandos não 
utilizaram lápis e/ou caneta para realizar os cálculos, simplesmente escolheram a opção e marcaram. Dentre estes, não se pode afirmar se utilizaram algum outro recurso para chegar ao resultado ou se estão com seu raciocínio lógico aprimorado, possibilitando assim, o cálculo mental. Cinco educandos não chegaram à resposta esperada.

$\mathrm{Na}$ questão 2, foi trabalhado o mesmo conteúdo da primeira questão, a fim de promover o acompanhamento do raciocínio dos educandos.

\section{Questão 2:}

Numa escola há $\mathbf{3 5}$ meninos na Educação Infantil. E a quantidade de meninas é o dobro dos meninos. Quantas meninas tem na Educação Infantil?
a) $\mathbf{4 0}$
b) 50
c) 60
d) 70

Ao analisar as soluções dos 26 educandos, foram observadas duas formas de solucionar o problema apresentado acima, além daqueles educandos que marcaram apenas as questões sem expor os cálculos realizados. Como afirma Neto $(2015$, p.3), "Cada aluno é capaz de produzir significados distintos, por meios diferentes de produção de significados numa mesma enunciação." Pode-se analisar essas duas produções de significados nas soluções da questão 2 :

$\mathrm{Na}$ imagem 2, verifica-se que a forma de resolução de 13 educandos foram à direção dos mesmos interlocutores, produzindo significados com as justificações apresentadas na imagem 2 , a seguir.

2 - Numa escola há 35 meninos na Educação Infantil. E a quantidade de meninas é o dobro dos meninos. Quantos meninos tem na Educação Infantil?
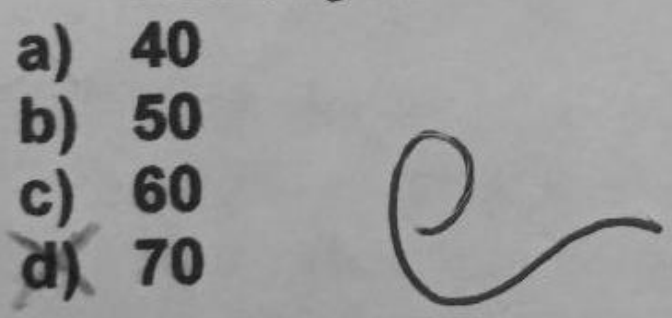

Imagem 2 - Resolução com Multiplicação 
$\mathrm{Na}$ imagem 3, observa-se a produção de significados de uma forma diferente, ou seja, o educando recorreu a outro caminho para justificar sua forma de resolver o problema, utilizando a adição para chegar ao resultado.

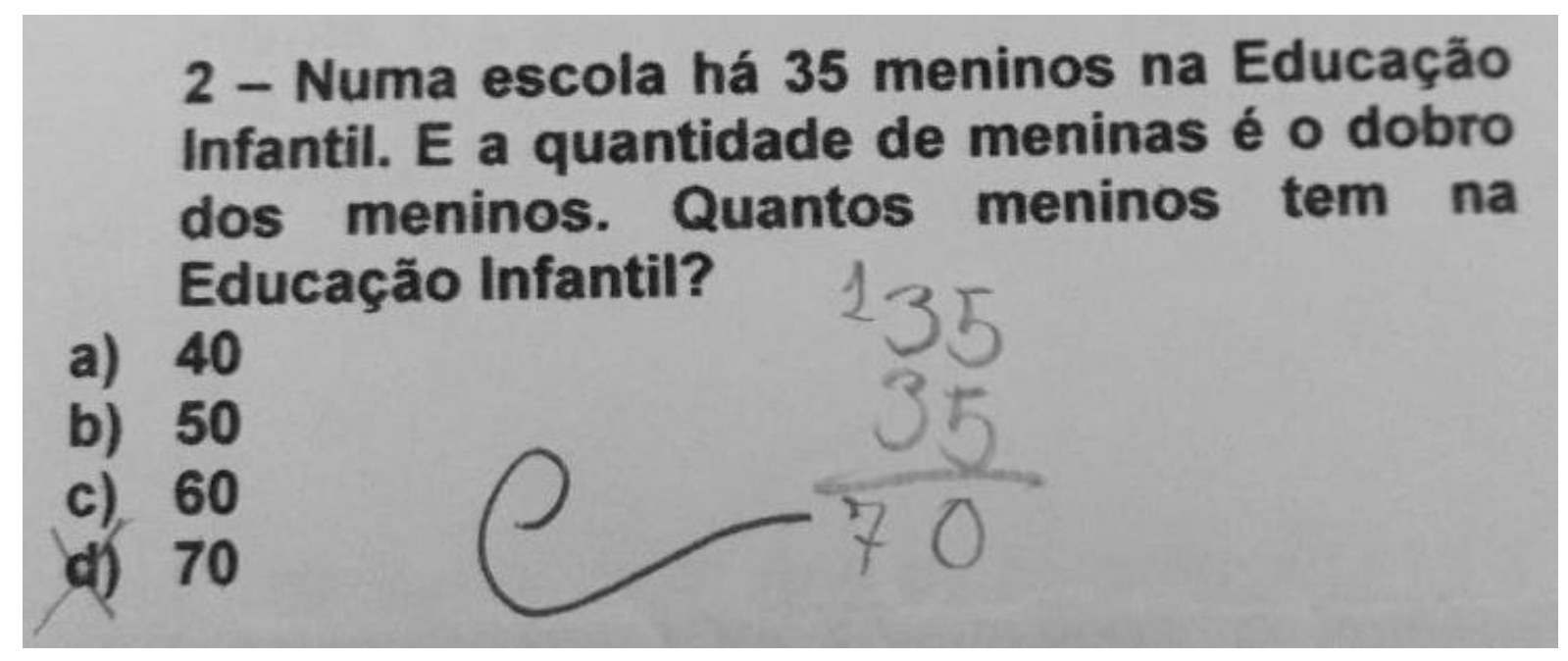

$$
\text { Imagem } 3 \text { - Resolução com adição }
$$

Ao final na análise da questão 2, observamos que 4 educandos não atingiram o objetivo e a produção de significados, pois apenas marcaram a alternativa incorreta, impossibilitando a análise da produção de significados.

$\mathrm{Na}$ questão 3, foi trabalhado o mesmo conteúdo das questões anteriores, a fim de promover o acompanhamento do raciocínio dos educandos.

\section{Questão 3:}

Na turma do $5^{\circ}$ Ano de Escolaridade há 4 tricolor (torcedor do Fluminense). 0 número de flamenguista (torcedor do Flamengo) é o quádruplo da quantidade de tricolores. Quantos flamenguistas tem nessa turma?
a) 16
b) 20
c) 24
d) 28

Ao realizar a observação das resoluções dos educandos, percebe-se a semelhança dos interlocutores entre 14 educandos que produziram significados e justificação, conforme apresentado na imagem 4: 


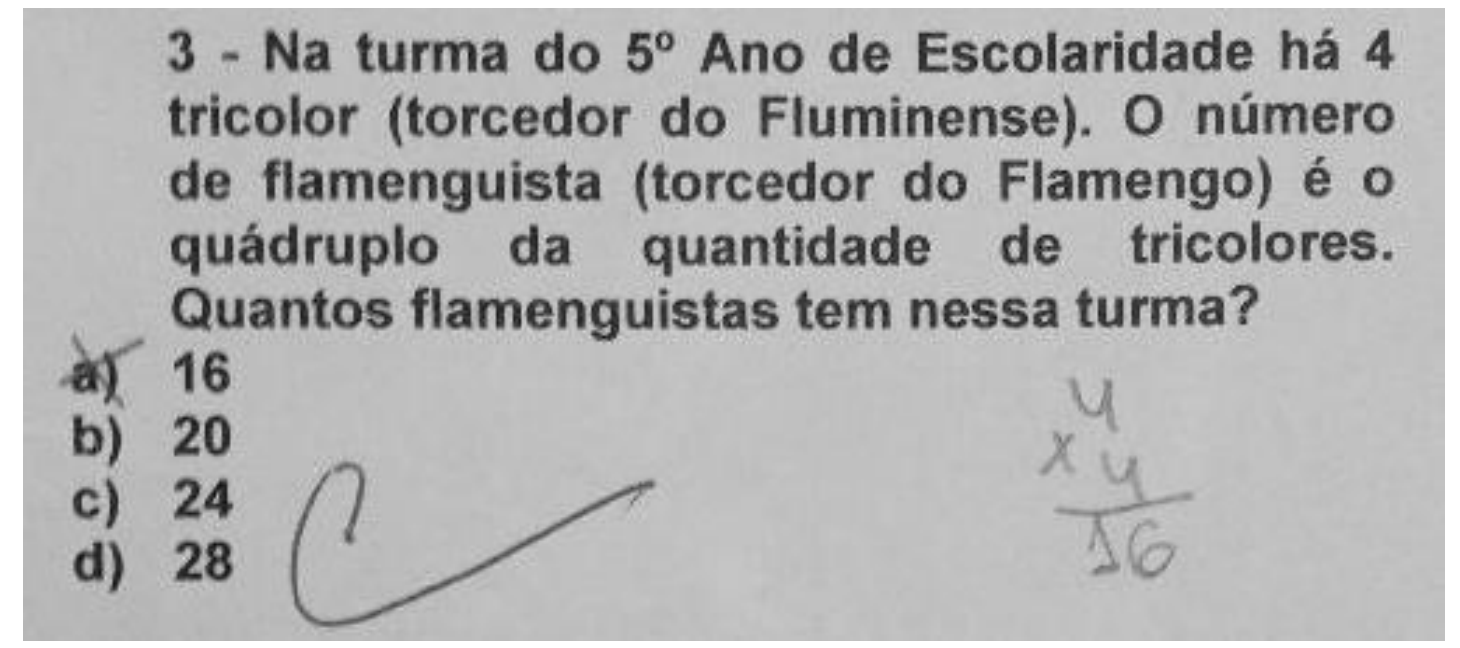

Imagem 4 - Resolução por Multiplicação

Ao término da análise da questão 3, nota-se que 2 educandos não atingiram o objetivo e a produção de significados. Eles apenas marcaram a alternativa incorreta, impossibilitando a análise da produção de significados. Vê-se que o número de educandos com resultados incorretos reduziu, pois na questão 1, obtivemos 5 erros, na questão 2, 4 erros e na questão 3, apenas 2 erros. Esses dados induzem a acreditar que houve uma evolução, ou seja, uma melhora no conhecimento dos educandos.

A partir da questão 4, foram trabalhados os conhecimentos envolvendo Multiplicação com números naturais, a tabuada.

\section{Questão 4:}

Uma família foi almoçar no restaurante que estava com a promoção de $\mathbf{R} \$ \mathbf{9 , 0 0} \circ$ prato de comida. Essa família é formada por 5 pessoas. Quanto gastaram com a alimentação nesse dia no restaurante?
a) $R \$ 40,00$
b) $R \$ 45,00$
c) $\mathbf{R} \$ \mathbf{5 0 , 0 0}$
d) $\mathbf{R} \$ 55,00$

Nessa questão, foi possível verificar que os educandos estão compartilhando o raciocínio lógico, pois 14 deles utilizaram a mesma organização do pensamento para resolver o problema, como pode ser analisado na imagem 5 : 


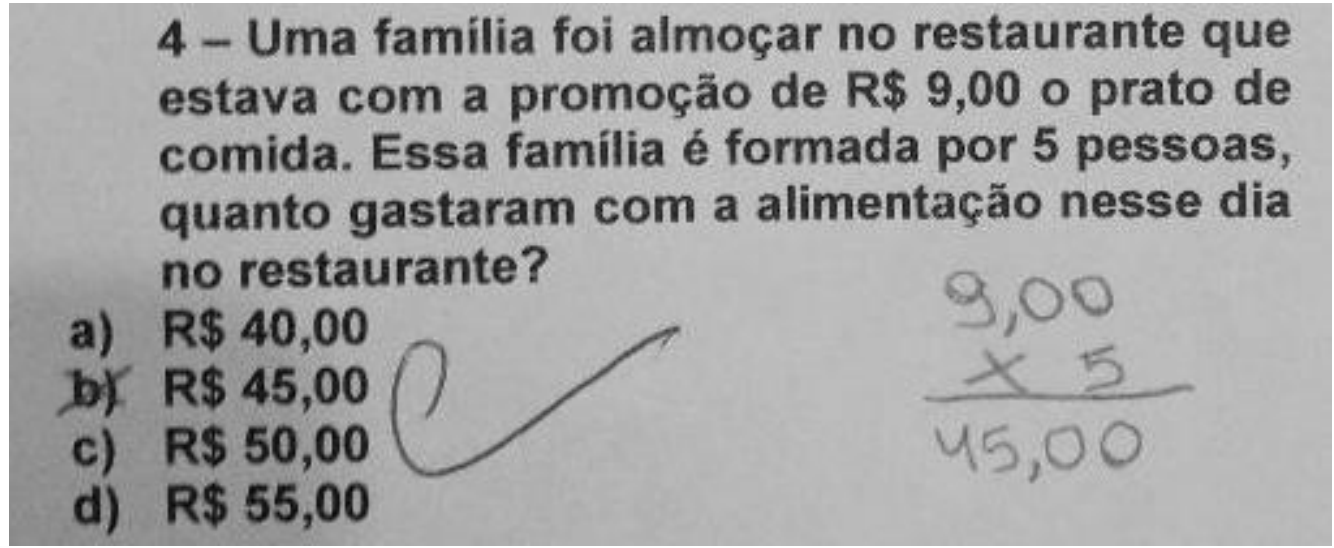

$$
\text { Imagem } 5 \text { - Resolução por Multiplicação }
$$

Ao analisar as produções dos educandos, foi possível notar a semelhança de interlocutores na produção de significados e justificações em suas conclusões. Nessa questão, apenas 2 deles não chegaram ao resultado.

$\mathrm{Na}$ questão 5 houve o mesmo desempenho, produção de significados e justificação elencados na questão 4. Ressalta-se que as análises escritas e as imagens dos materiais foram enviados aos educandos de forma remota, impressa.

\section{Questão 5:}

A sorveteria vende picolé por $\mathrm{R} \$ 3,00$. Quanto gastarei se levar meus 6 sobrinhos na sorveteria e comprar um picolé para cada um sobrinho?
a) $R \$ 12,00$
b) $R \$ 15,00$
c) $R \$ 18,00$
d) $R \$ 21,00$

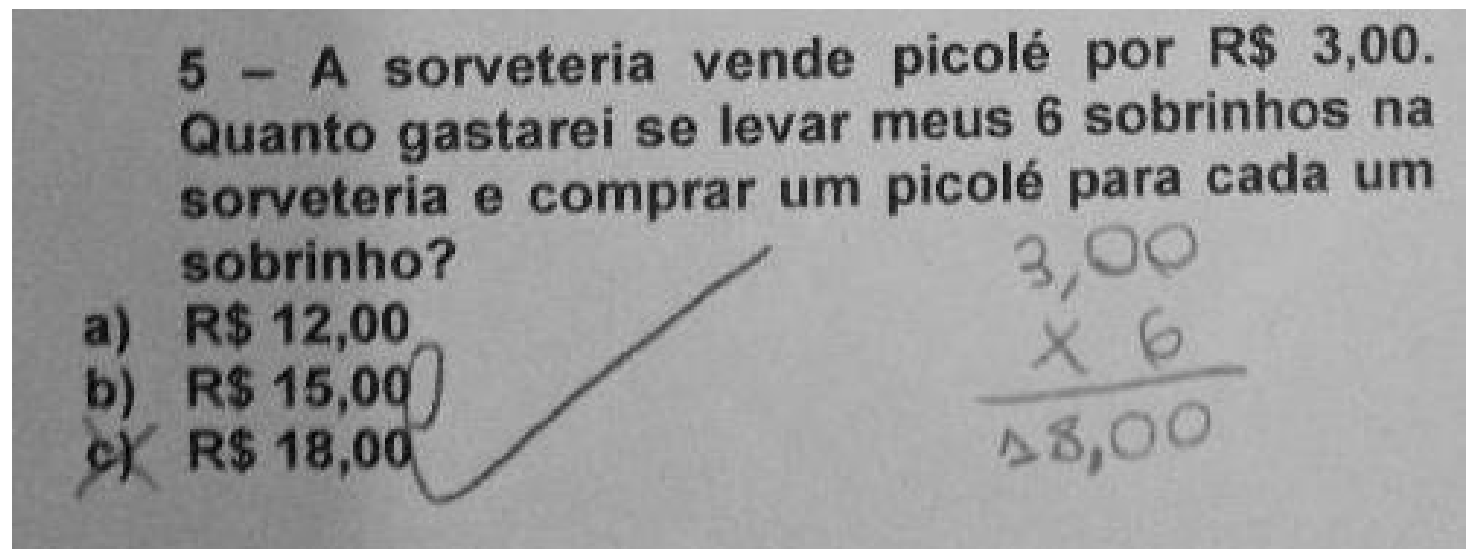

Imagem 6- Resolução por Multiplicação

A questão 6 segue o mesmo conteúdo das questões 4 e 5 e os educandos apresentaram formas diferentes na resolução.

\section{Questão 6:}


O ônibus escolar possui 16 lugares do lado direito e a mesma quantidade de acentos no lado esquerdo. Quantos acentos há nesse ónibus para os alunos?
a) 30
b) 32
c) 34
d) 36

Nessa questão, observa-se que os educandos não compartilharam os mesmos interlocutores. A produção de significados e justificação de 12 foi por meio da operação adição, conforme imagem 7:

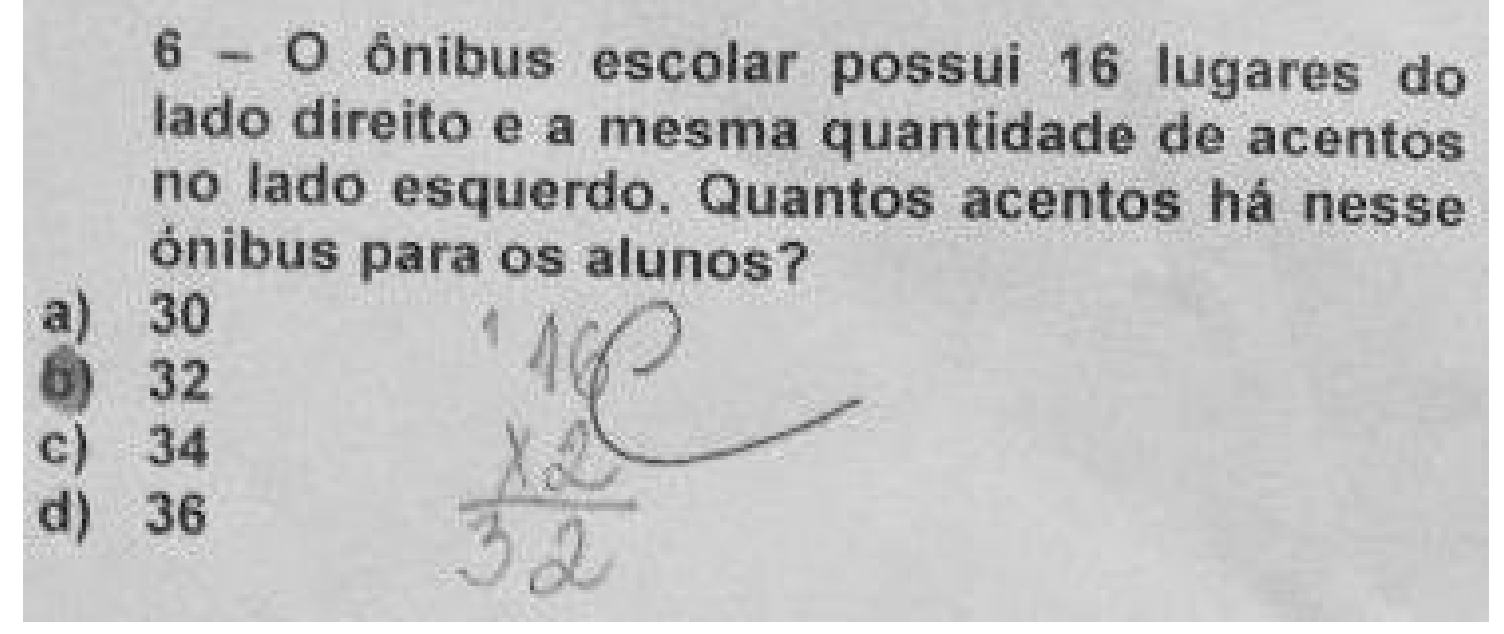

Imagem 7 - Resolução por Multiplicação

Outros 3 educandos apresentaram interlocutores semelhantes. Isso leva a concluir que produziram significados a partir das justificações apresentadas com os cálculos da multiplicação, conforme ilustrado na imagem 8 :

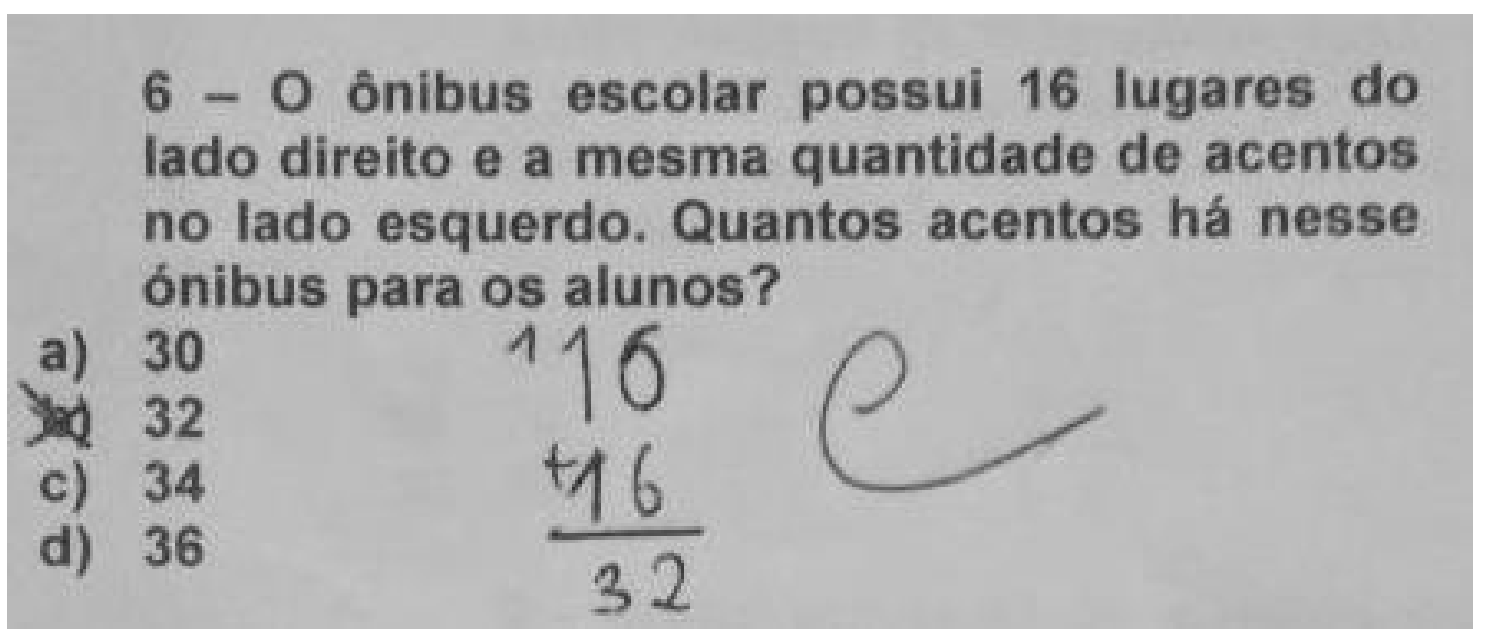

Imagem 8 - Resolução por Adição

Verifica-se nessa questão que cada educando produz seu significado e essa produção pode ser realizada de diferentes formas. 
$\mathrm{Na}$ questão 7, apresentaram interlocutores semelhantes na produção de significados e justificação. Foram 14 educandos que apresentaram soluções, conforme a imagem 9:

\section{Questão 7:}

A professora Josiane gasta $R \$ 7,00 \mathrm{com}$ passagem para ir trabalhar por dia. Ela trabalha 4 vezes na semana. Quanto ela gasta por semana com passagem?
a) $R \$ 28,00$
b) $R \$ 35,00$
c) $R \$ \mathbf{4 2 , 0 0}$
d) $R \$ 49,00$

Nessa questão, apenas 3 não compreenderam ou não conseguiram chegar ao resultado esperado.

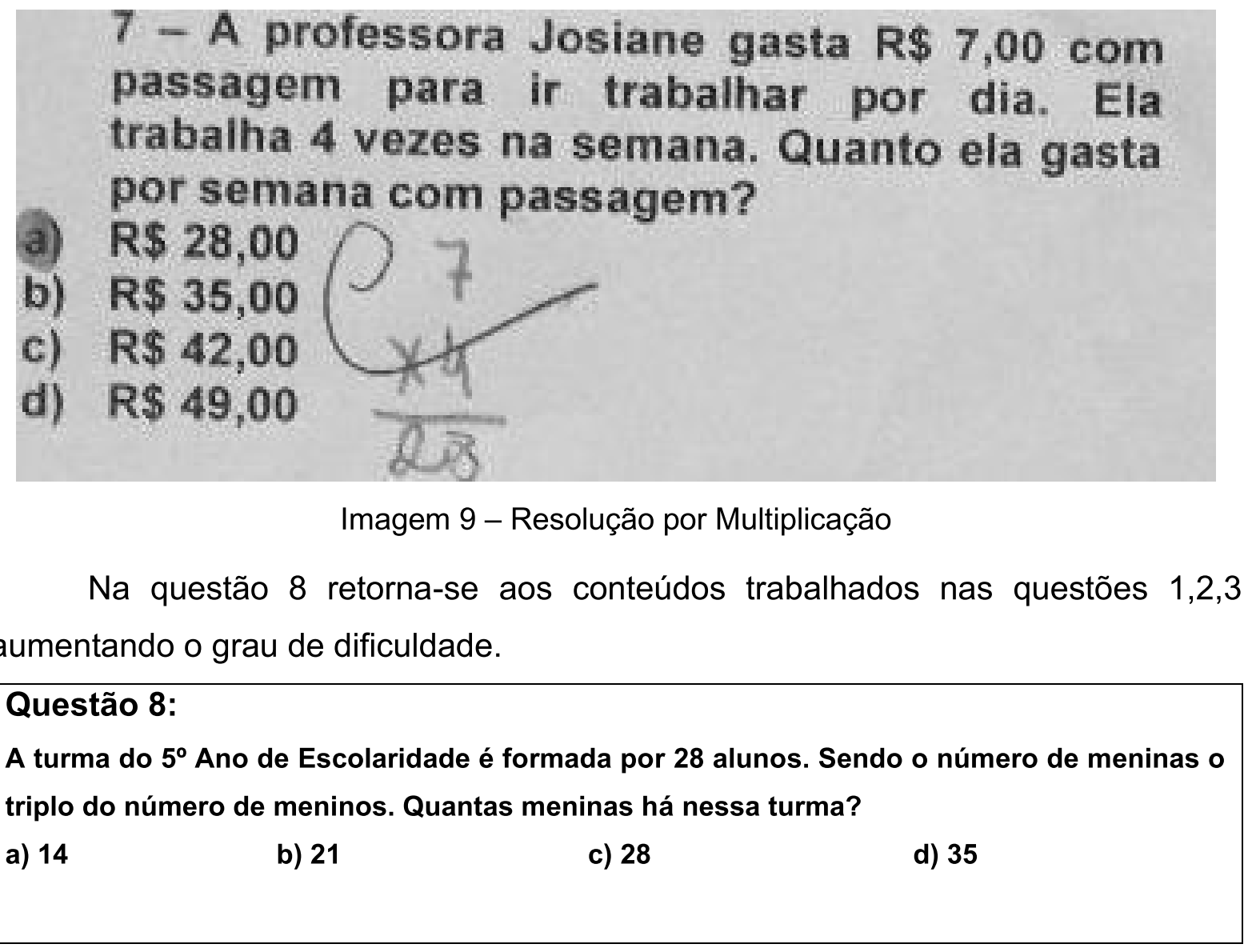

Após analisar os materiais devolvidos pelos educandos, nota-se que apenas 3 conseguiram compartilhar seus diferentes interlocutores, como segue nas imagens 10, 11 e 12: 


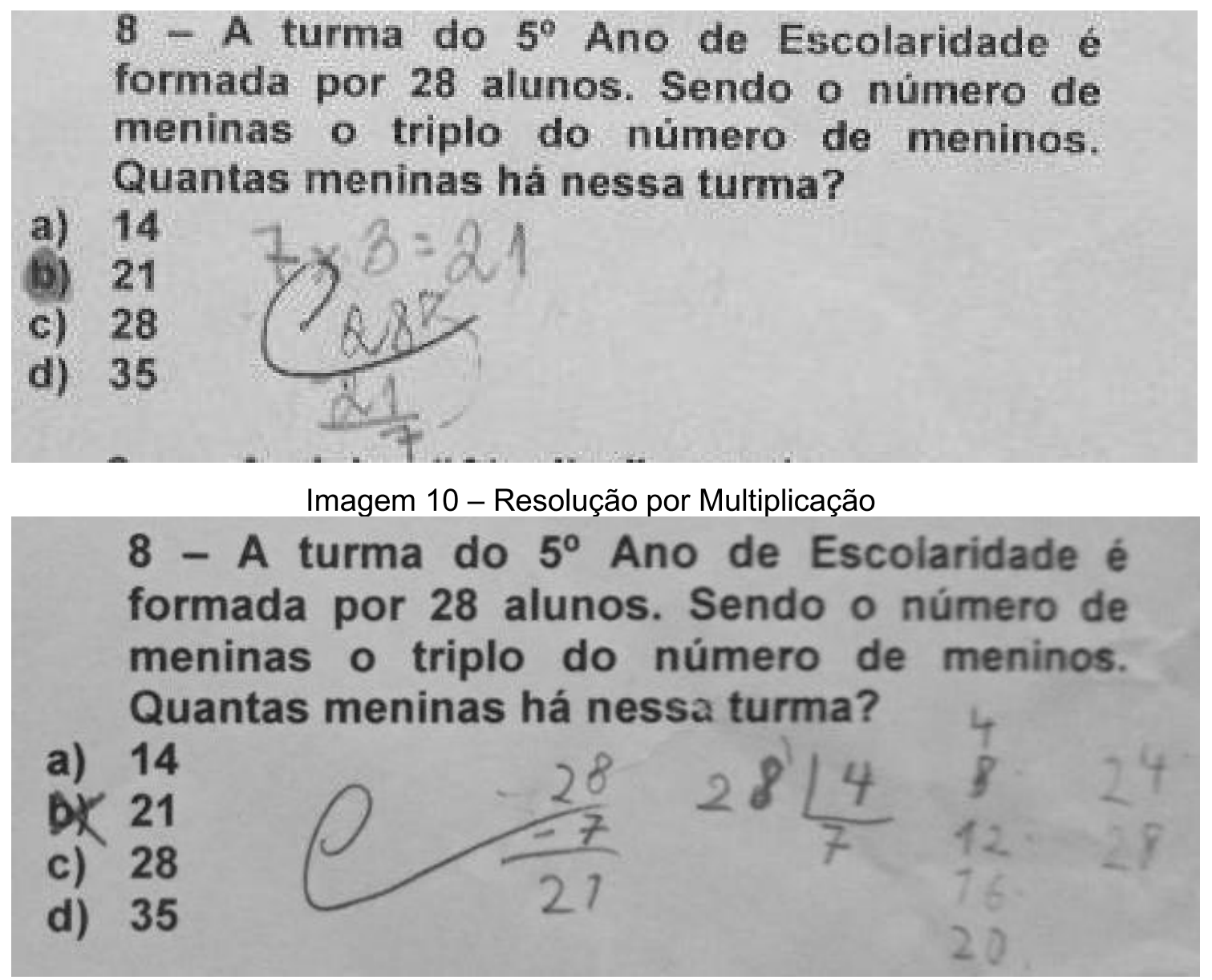

Imagem 11 - Resolução por Divisão e Subtração

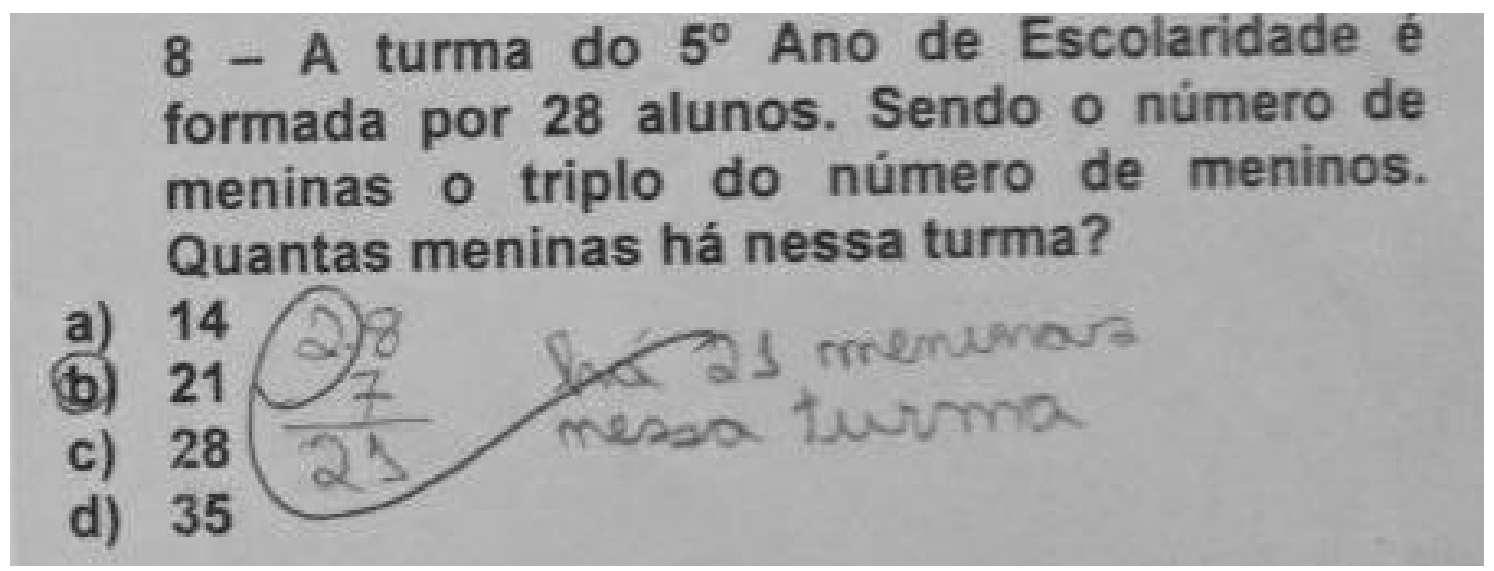

Imagem 12- Resolução por Subtração

Os educandos apresentaram dificuldades em resolver essa questão. Houve intervenção do professor e pesquisador a fim de que eles pudessem compreender e compartilhar interlocutores, a partir do grupo de WhatsApp. Com isso, produziram significados e apresentaram suas justificações de diferentes formas, conforme segue no tópico 6.2. Esta questão será analisada juntamente com as contribuições compartilhadas entre os educandos no grupo. Outros 2 educandos buscaram 
solucionar o problema, mas não conseguiram chegar ao resultado, conforme imagens 13 e 14:

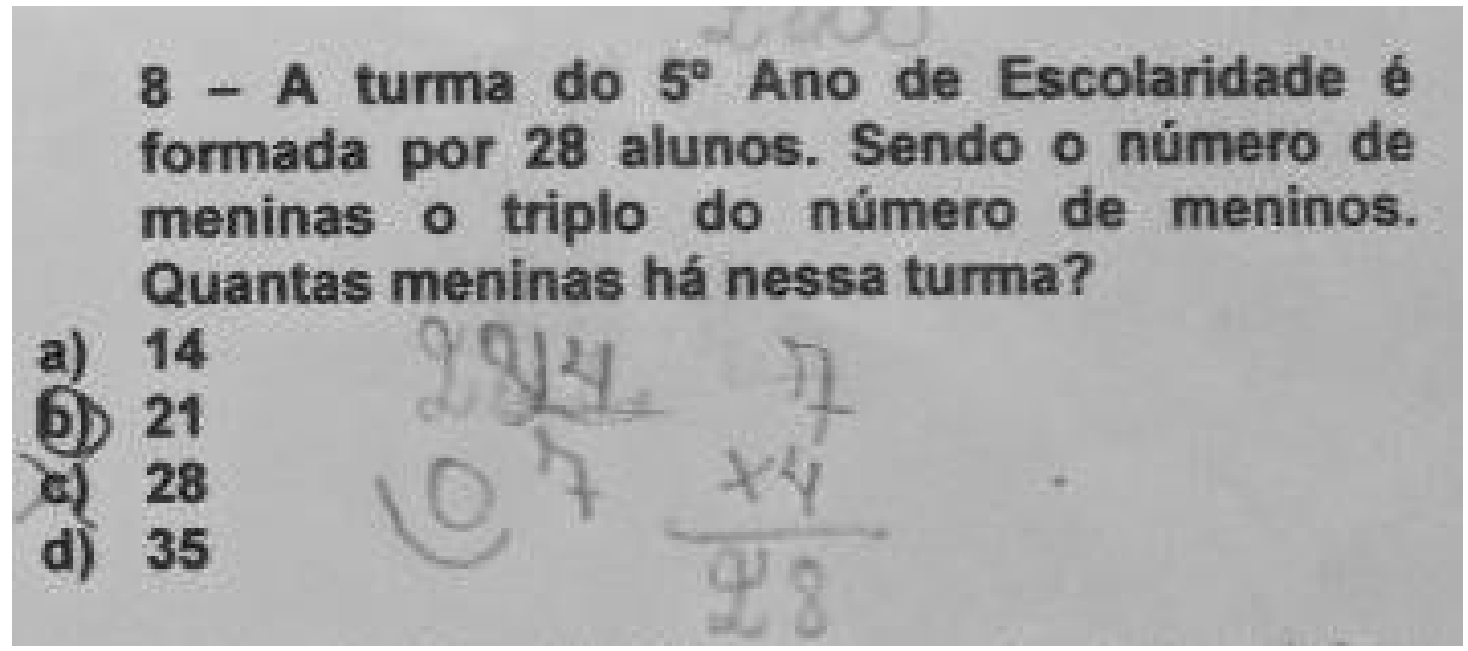

Imagem 13 - Resolução incorreta por Multiplicação e Divisão

$\mathrm{Na}$ imagem 13, observa-se que o educando utilizou interlocutores corretos, mas não conseguiu finalizar o raciocínio para chegar a uma conclusão correta. Isso comprova que pode ter ocorrido produção de significados, mesmo não concluindo corretamente a questão. Já na imagem 14, nota-se que o educando não utilizou os interlocutores adequadamente, impossibilitando a produção de significados.

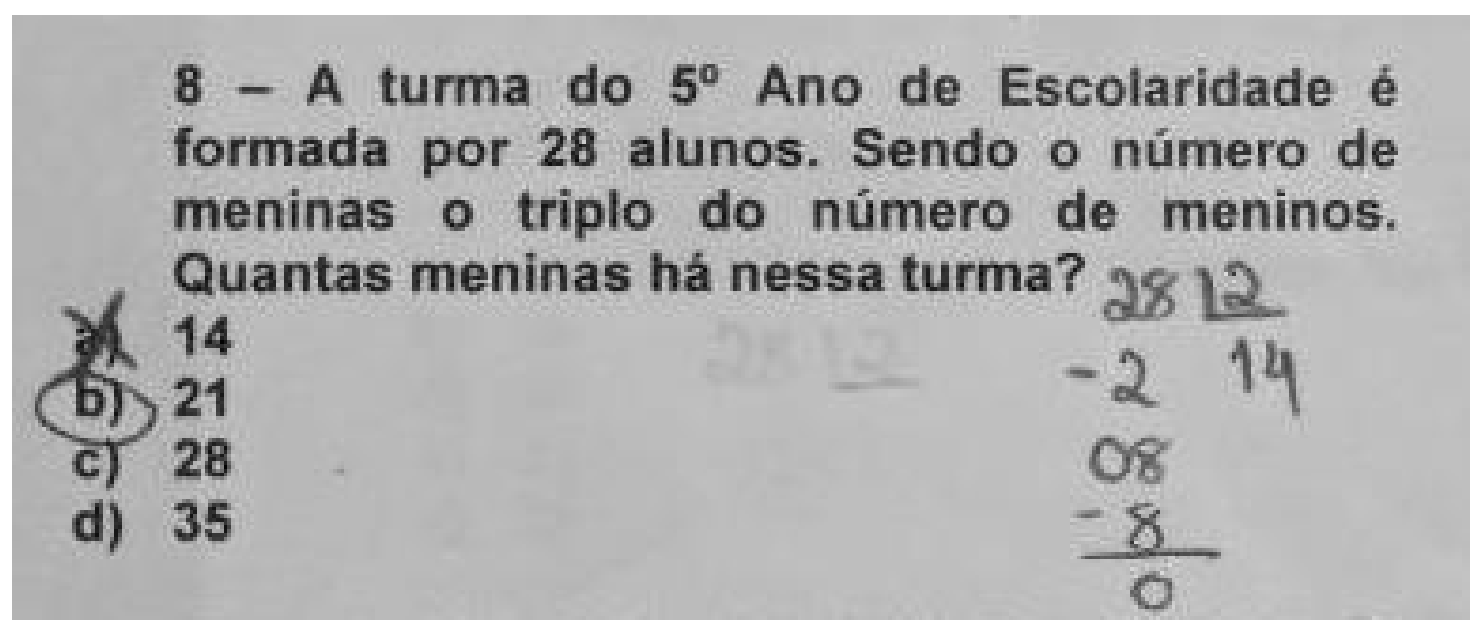

Imagem 14 - Resolução incorreta por Divisão

As questões 9 e 10 apresentam os conteúdos envolvendo Multiplicação a fim de analisar a produção de significados e justificações dos educandos.

\section{Questão 9:}

A loja "Atualize" vende pacote de figurinhas por $\mathbf{R} \$ \mathbf{8 , 0 0}$. Dênis comprou quatro pacotes de figurinhas. Quanto Dênis pagou no caixa da loja?
a) $R \$ 16,00$
b) $R \$ 24,00$
c) $R \$ 32,00$
d) $\mathbf{R} \$ \mathbf{4 0 , 0 0}$ 


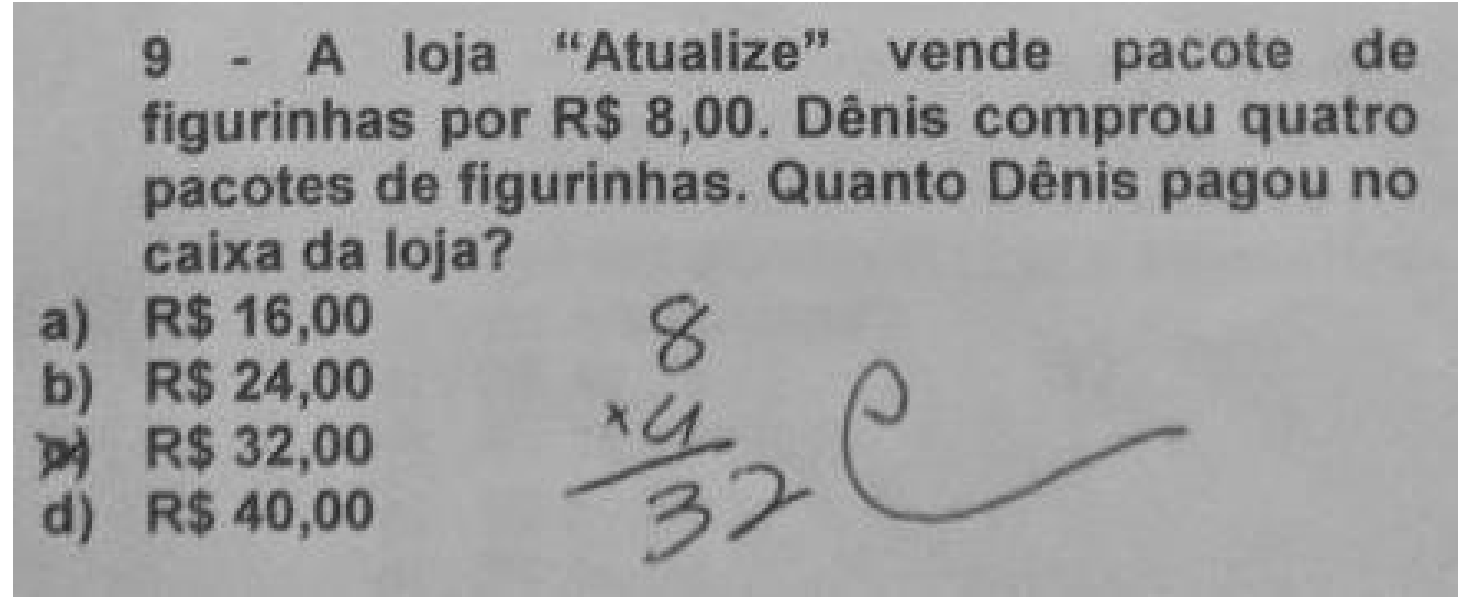

Imagem 15- Resolução por Multiplicação

\section{Questão 10:}

Uma sala de aula tem 5 fileiras de carteiras para os alunos sentarem. Sabendo que cada fileira possui 6 carteiras, determine quantas carteiras há nessa sala de aula?
a) 15
b) 20
c) 25
d) 30

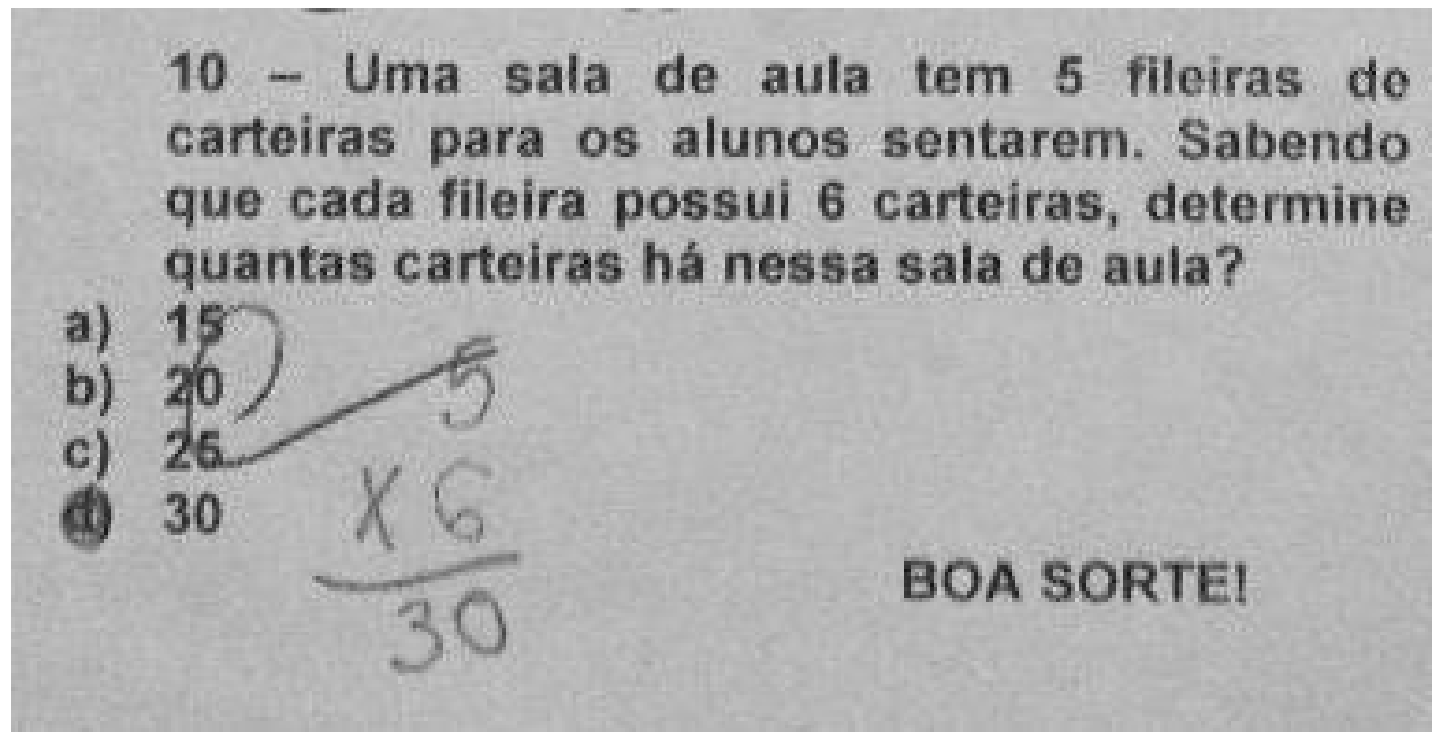

Imagem 16- Resolução por Multiplicação

Em ambas as questões, 14 educandos apresentaram os mesmos interlocutores, produção de significados e justificações conforme figuras 15 e 16 . Após análise e verificação dos significados nas questões supracitadas, percebe-se que as questões envolvendo multiplicação apresentaram potencialidades e produção de significados semelhantes de acordo com os apresentados nas imagens acima, em que os educandos compartilham interlocutores, do Modelo dos Campos Semânticos. Acredita-se que as tarefas utilizando os recursos tecnológicos será enriquecido por se tratar de uma ferramenta do interesse dos educandos. A partir da 
análise das questões, sintetizam-se os resultados no quadro 8 , demonstrando os acertos com cálculos, acertos sem cálculos e a quantidade de educandos que não acertaram as questões partindo de uma análise dos materiais impressos, que thes foram enviados mediante o cenário de Pandemia vivenciado atualmente.

Quadro 8 - Resultados das tarefas

\begin{tabular}{|l|c|c|c|c|}
\hline No da Questão & $\begin{array}{c}\text { Acertos com } \\
\text { cálculos }\end{array}$ & $\begin{array}{c}\text { Acertos sem } \\
\text { cálculos }\end{array}$ & Não acertaram & Total \\
\hline Questão 1 & 15 & 6 & 5 & 26 \\
\hline Questão 2 & 14 & 8 & 4 & 26 \\
\hline Questão 3 & 13 & 11 & 2 & 26 \\
\hline Questão 4 & 14 & 10 & 2 & 26 \\
\hline Questão 5 & 14 & 9 & 3 & 26 \\
\hline Questão 6 & 14 & 11 & 1 & 26 \\
\hline Questão 7 & 14 & 9 & 3 & 26 \\
\hline Questão 8 & 3 & 11 & 12 & 26 \\
\hline Questão 9 & 14 & 10 & 2 & 26 \\
\hline Questão 10 & 14 & 9 & 3 & \\
\hline
\end{tabular}

Observa-se nos dados do quadro 8 , que os educandos que realizaram os cálculos de forma impressa têm um grau de aprendizagem semelhante, pois suas respostas e cálculos seguiram o mesmo raciocínio lógico, ou seja, a organização do pensamento para uma tomada de decisão coerente com resolução do problema de forma correta a partir da análise dos argumentos apresentados. Pode-se afirmar esse fato a partir dos resultados com cálculos realizados pelos educandos, conforme supracitado. Os seus resultados que não chegaram a uma resposta correta ocorreram de forma equilibrada, ou seja, foram poucos que não chegaram à produção de significados. Nesses casos, observou-se as dificuldades referentes à base para esses conteúdos que são conhecimento sobre a tabuada.

6.2 - Descrição dos resultados das discussões ocorridas no grupo de WhatsApp a partir do desenvolvimento das tarefas propostas de forma remota

Durante o período que os educandos estiveram com as tarefas impressas, ocorreram as discussões pelo grupo de WhatsApp. Dos 56 que receberam as tarefas impressas, apenas 36 possuem acesso à internet e WhatsApp e participaram do grupo. Foram criados nomes não reais para os educandos participantes da pesquisa, 
devido às dificuldades de envio do formulário aos responsáveis solicitando autorização para uso dos nomes e imagens do grupo de WhatsApp. Alguns educandos destacaram no privado que, para obter acesso à internet, precisava deslocar-se para casa de vizinhos ou parentes. Mediante essas dificuldades, expõese uma análise dos resultados que se obteve no decorrer da pesquisa nesse grupo e verificar a produção de significados a partir do Modelo dos Campos Semânticos proposto por Lins (2002).

Nessa fase da pesquisa, será possível identificar as dificuldades de aprendizagens, a formulação de raciocínio lógico e a maneira que alguns educandos executaram as tarefas ou tentaram ajudar os colegas de classe.

A questão de número 8 foi escolhida para realizar a análise e a verificação da produção de significados devido às discussões no grupo de WhatsApp terem acontecido referente e exclusivamente a esta questão, que chamou atenção por causa da disparidade dos resultados obtidos quanto à forma de resolução das questões, pois a maioria dos educandos resolveram todas as questões utilizando lápis e papel para efetuar os cálculos nas folhas de atividades, diferente dessa questão, em que apenas três educandos conseguiram efetuar os cálculos e chegar à resposta correta, outros onze educandos optaram apenas por marcar a resposta, sem expor o raciocínio e os cálculos e doze deles não conseguiram chegar à resposta.

Ressalta-se que a questão 8 trata do tema Numerais Multiplicativos e o objetivo é o desenvolvimento do raciocínio lógico a partir da organização do pensamento para uma tomada de decisão coerente na resolução do problema de forma correta com a análise dos argumentos apresentados.

\section{Questão 8:}

A turma do $5^{\circ}$ Ano de Escolaridade é formada por 28 alunos. Sendo o número de meninas o triplo do número de meninos. Quantas meninas há nessa turma?
a) 14
b) 21
c) 28
d) 35

Iniciou-se a análise das conversas do grupo de WhatsApp referente à questão 8, observando o diálogo constante na Imagem 17. A conversa deu início na data 25 de novembro de 2020 e participaram os educandos Valéria, Vanessa, Ellen, Vitória, Ellen Fátima e Flavio, educandos com nomes não reais, devido à dificuldade de contato com eles e seus responsáveis, como exposto no início dessa análise. 


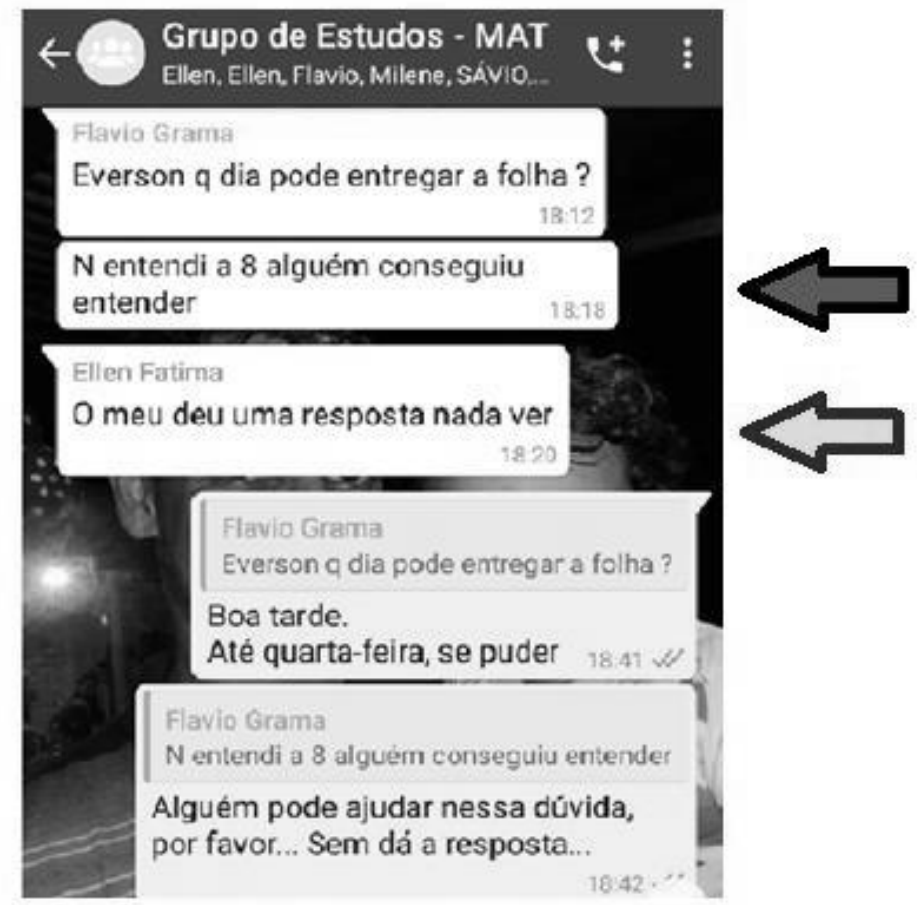

Imagem 17 - Informação e dúvida

Conclui-se que o aluno Flávio não conseguiu entender a questão 8 e solicitou ajuda aos demais colegas. Para destacar esse o pedido de ajuda, é utilizada a seta vermelha. A aluna Ellen Fátima também demonstrou sua dúvida afirmando que seu resultado "deu uma resposta nada a ver", conforme imagem 17, indicado pela seta amarela. A partir dessas dúvidas, o pesquisador e o professor da turma interagiram solicitando ajuda aos demais educandos.

Logo em seguida, a aluna Ellen deixou sua contribuição, conforme a imagem. 18: 


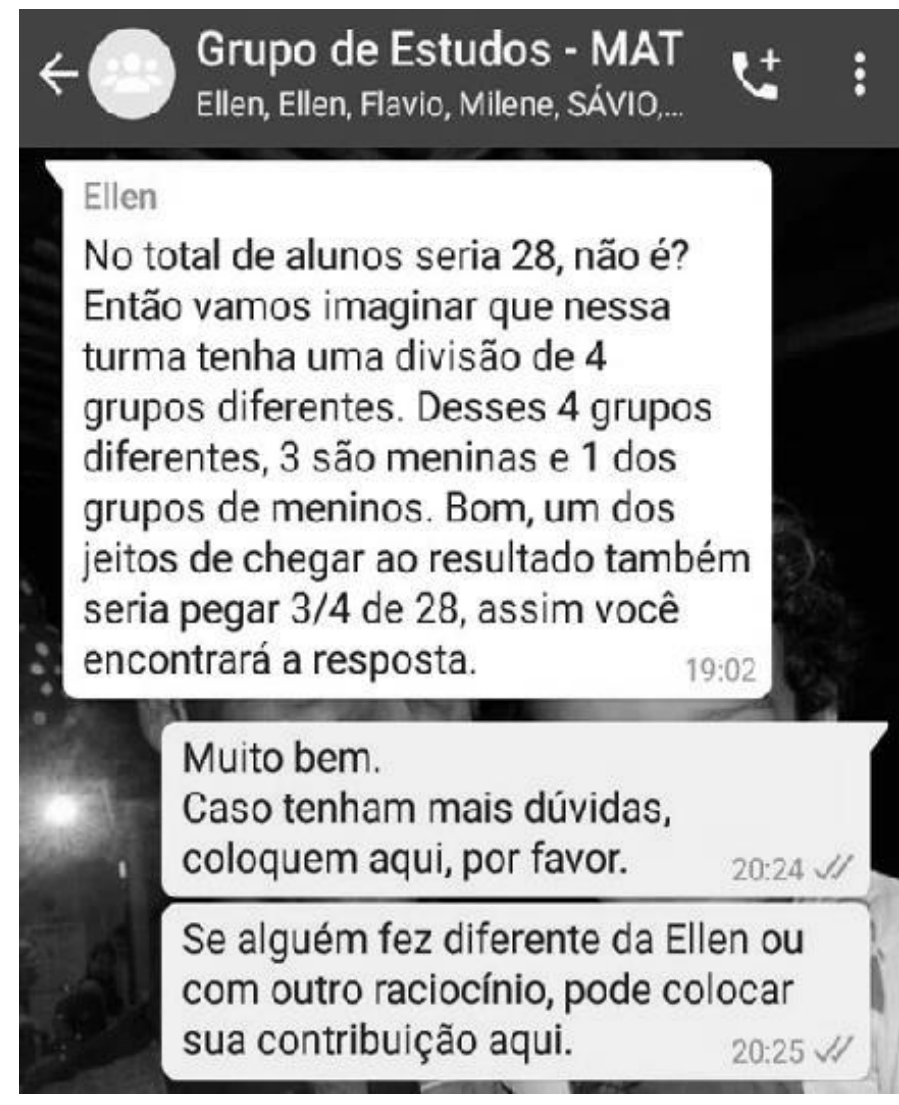

Imagem 18 - Explicação

Nessa postagem da Imagem 18, pode-se notar que a aluna deixou duas contribuições, ou seja, duas formas para resolver a referida questão. A primeira envolvendo a multiplicação e divisão com Números Naturais e a segunda com multiplicação de frações. Os referidos colegas Ellen Fátima e Flávio não mencionaram no grupo do WhatsApp se chegaram ao resultado com o exposto pela colega naquele momento. Contudo, ao analisar a resolução do aluno Flávio enviado de forma remota, observa-se a seguinte solução:

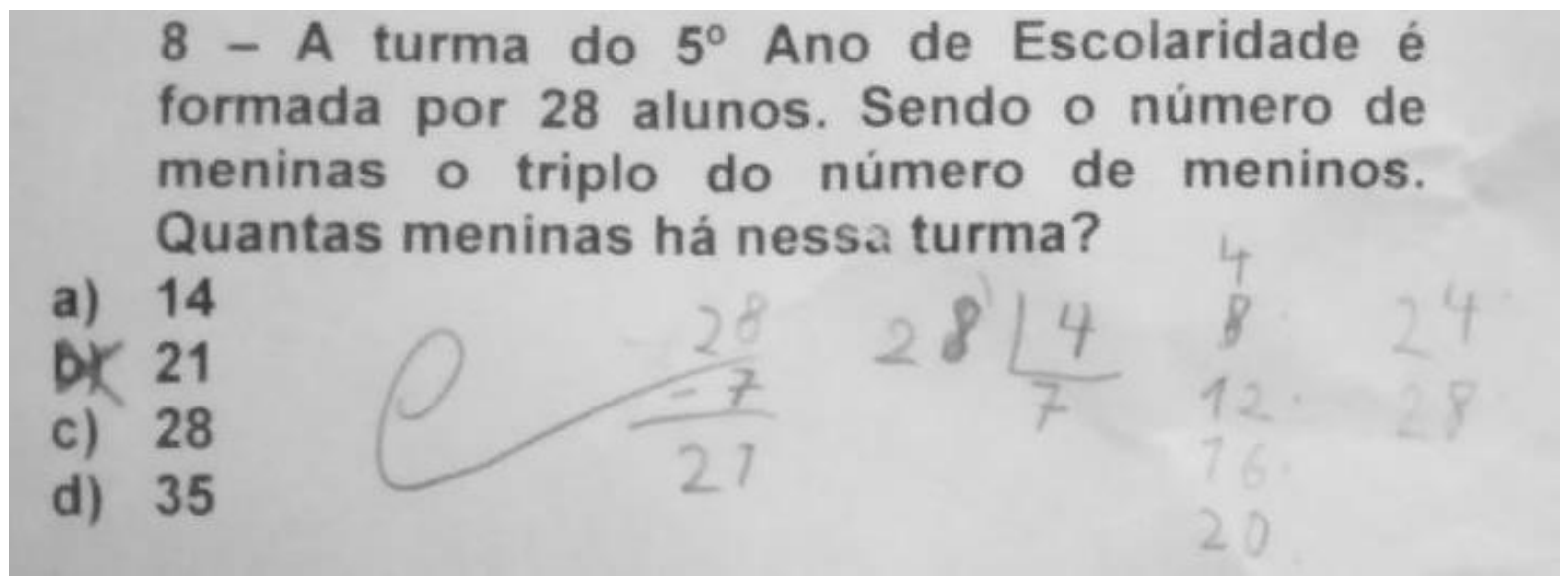

Imagem 19 - Resolução por Divisão 
A partir das orientações da aluna Ellen, percebe-se que o aluno Flávio desenvolveu e seguiu o primeiro raciocínio da colega. Ele montou a tabuada de 4 , depois desenvolveu a divisão de 28 por 4 , seguida da subtração de 28 por 7 , chegando à conclusão que o triplo do número de meninas corresponde a 21 educandos. Através do Modelo dos Campos Semânticos pode-se afirmar que houve a produção de significados quando a aluna Ellen expôs seus conhecimentos e formas de resolver e o aluno Flávio desenvolveu seus cálculos com as estratégias utilizadas envolvendo a montagem da tabuada, a subtração e a divisão. Afirma-se que o Modelo que a interação via WhatsApp gerou essa produção de significados. A aluna Ellen conseguiu demonstrar, na perspectiva do MCS, o desencadeamento do processo para que o aluno Flávio pudesse constituir o objeto, formar um núcleo a partir das operações realizadas, identificando o interlocutor e demonstrando no término da questão a produção de significados. No dia seguinte, a aluna Vanessa solicitou ajuda para resolver a mesma questão, já que estava com dificuldades em chegar à resposta, conforme Imagem 20.

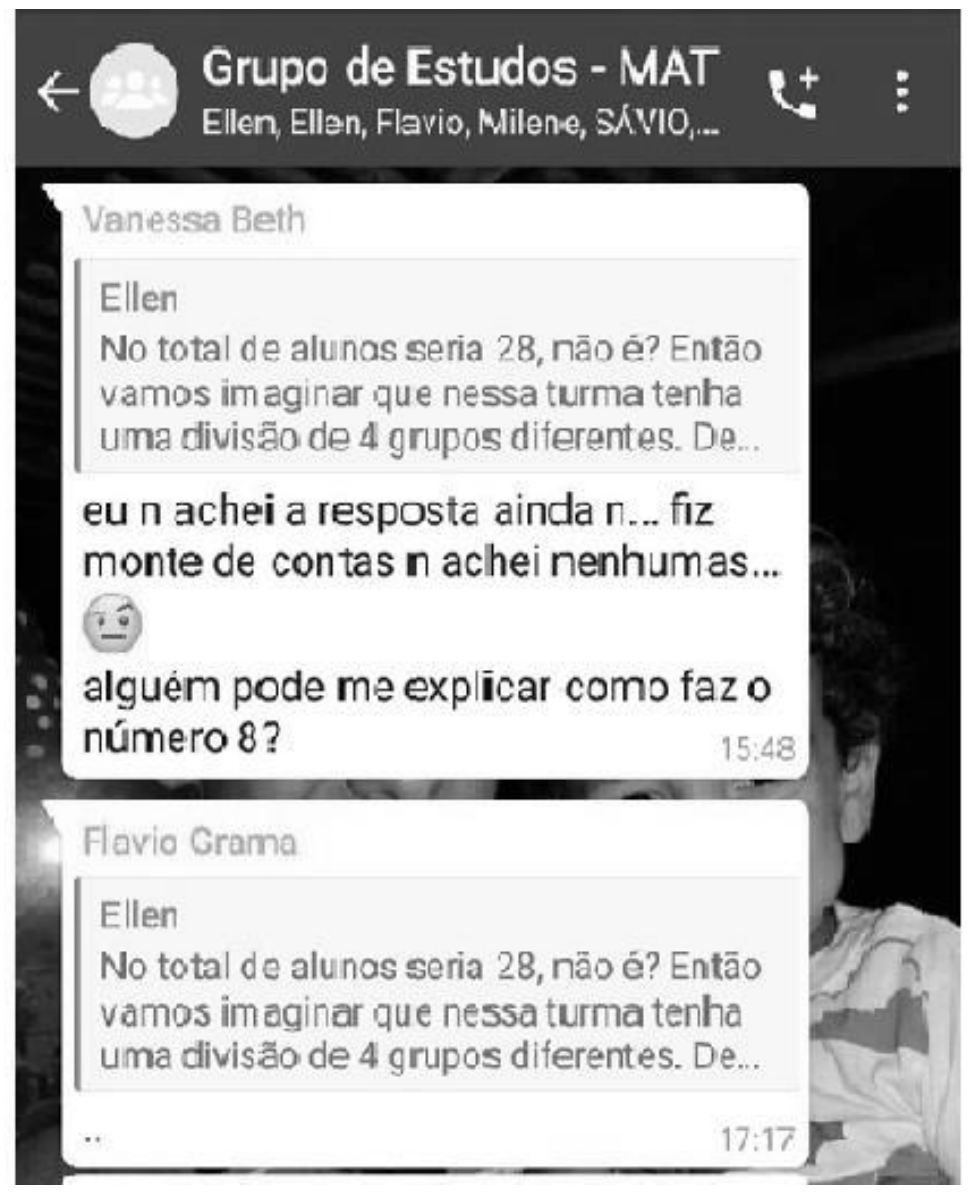

Imagem 20 - Apontamento de dúvida 
Tendo produzido significados e mediante o silêncio prolongado no grupo, o aluno Flávio indicou a explicação da aluna Ellen, no dia anterior, para solucionar a questão. Com isso, acredita-se que a explicação e a produção de significados foram satisfatórias para esse aluno, diferente da Vanessa, que ainda não havia conseguido uma estratégia para solucionar o problema. Segundo Neto (2015) "Cada aluno é capaz de produzir significados diferentes, por meios diferentes de produção de significados numa mesma enunciação. (p.3)". Sendo assim, uma estratégia pode ser eficaz para determinado educando e não obter êxito para outros, como ocorreu com a aluna Vanessa. Por isso, há necessidade de buscar e disponibilizar diferentes estratégias para solucionar os problemas. No dia seguinte, a aluna Vitória postou outra estratégia para essa resolução, conforme a imagem 21:

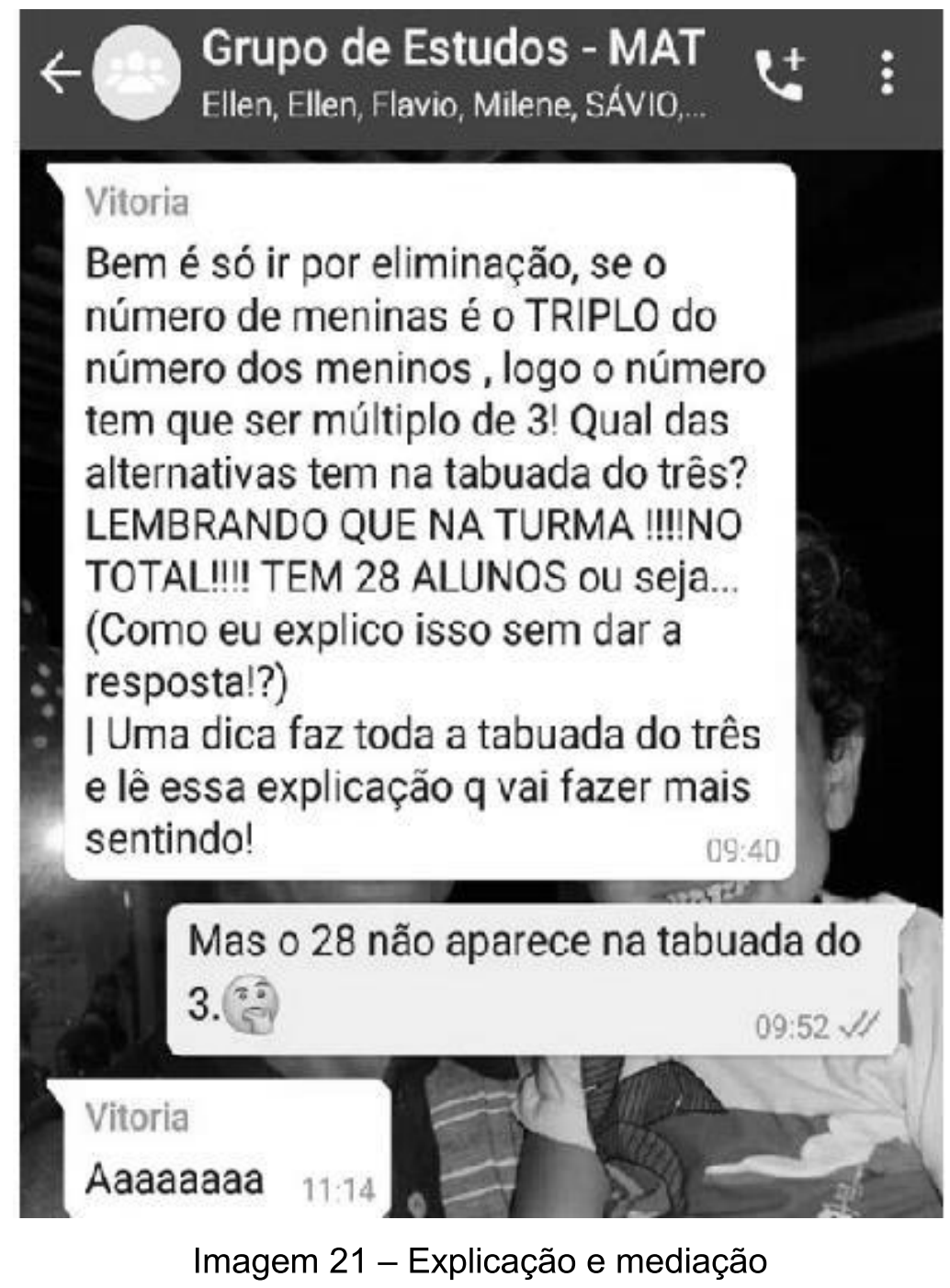

Nessa explicação, a aluna Vitória se equivocou indicando que o número deveria ser múltiplo de 3 , pois chegou a essa conclusão devido à palavra "triplo" da questão. Seu raciocínio estaria correto se indicasse os múltiplos de 4. 
Como a aluna indicou a tabuada de 3 , ocorreu a intervenção do docente pesquisador solicitando a revisão da indicação. O raciocínio estava no "caminho certo", bastava uma adequação. Com isso, a aluna indicou os múltiplos de 7 que também a permitiu chegar ao resultado esperado. A partir dessas interações e a imagem 22, chega-se à seguinte conclusão:

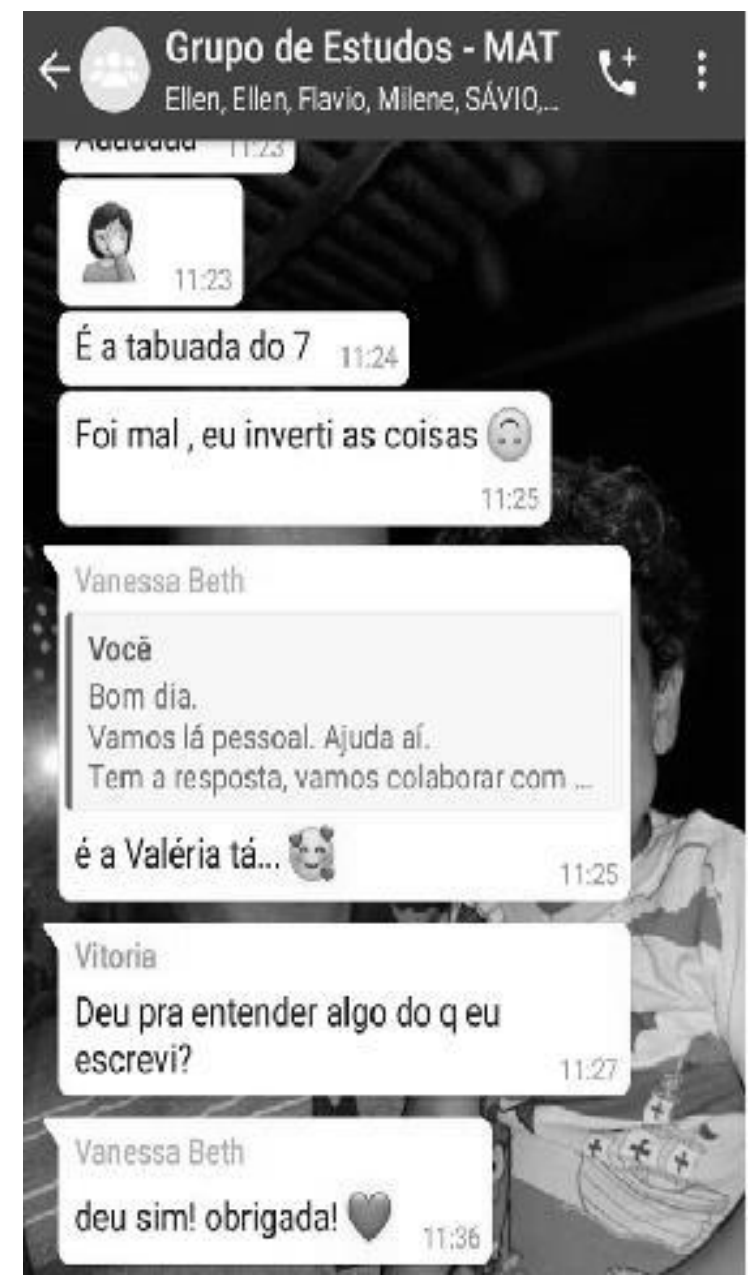

Imagem 22 - Interação e conclusão

Pode-se notar que ocorreram duas produções de significados nas duas últimas imagens. A primeira foi da aluna Vitória, que estava utilizando uma estratégia coerente, mas com o múltiplo errado. Com a intervenção do docente, ela notou seu equívoco e indicou um novo múltiplo para a colega, que conseguiu desenvolver seu raciocínio e chegar a uma resposta, conforme verifica-se na imagem 8 : 


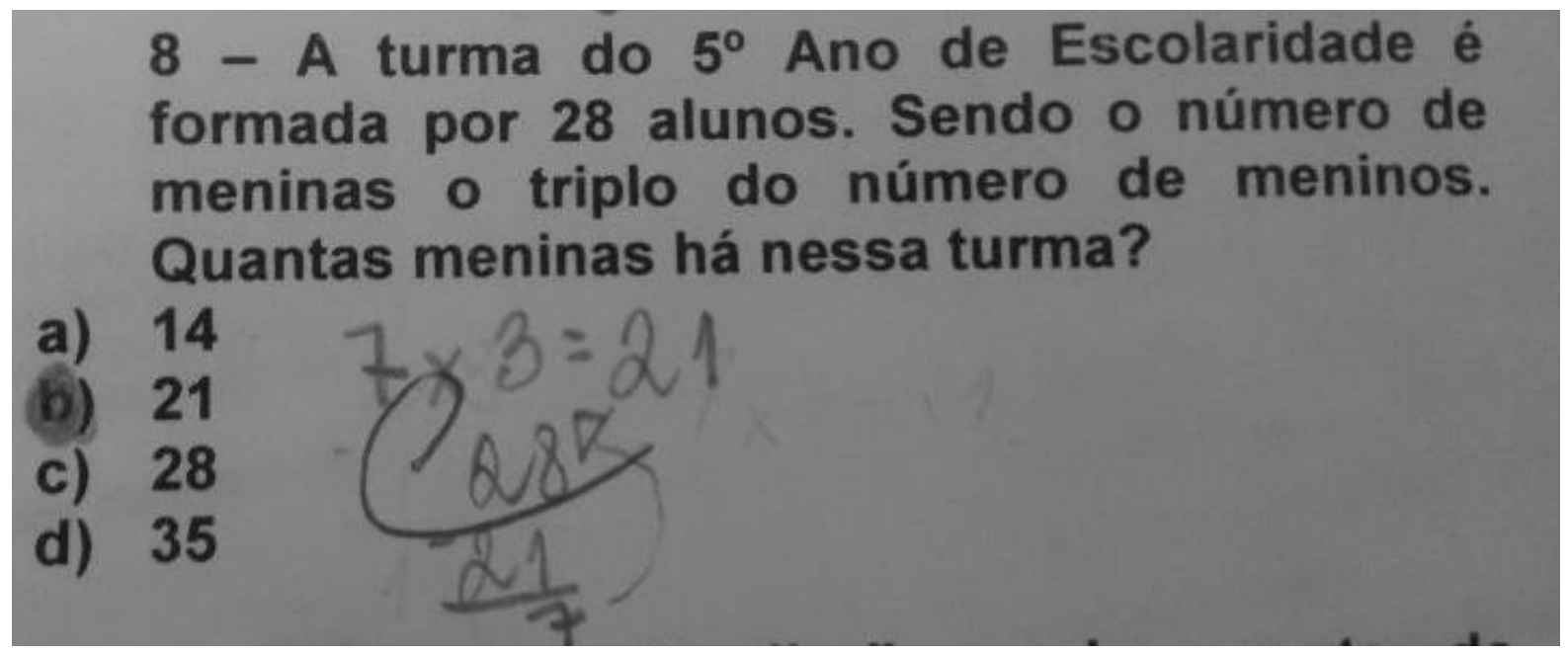

Imagem 23 - Resolução por Multiplicação

$\mathrm{Na}$ imagem 23, foi possível observar que a aluna Vanessa seguiu as orientações da aluna Vitória no desenvolvimento do seu raciocínio. As produções de significados de Vitória e Vanessa, nessa questão, mostram que ambas operaram utilizando a tabuada, ou seja, os cálculos envolvendo a multiplicação. Mediante o exposto acima, afirma-se que houve produção de significados quando a aluna Vitória diz "- Foi mal, eu inverti as coisas", ou seja, ela observou que estava equivocada e conseguiu alinhar seus pensamentos para obter os resultados. $E$, também, quando a aluna Vitória questiona “-Deu pra entender algo do q eu escrevi?" e, logo em seguida, a aluna Vanessa responde "deu sim! obrigada!", nota-se, com essa situação, a produção de significados exposta na imagem 8.

Nessas duas situações, verifica-se que houve a produção de significados, pois a partir de Silva e Lins (2003), tal produção pode desencadear nas operações, na lógica e na direção de interlocutores os quais as educandas apresentam nessa situação, uma vez que elas apresentam suas estratégias e concluem suas atividades de forma satisfatória, compartilhando os interlocutores.

O nível de dificuldade das tarefas propostas foi baseado a partir do conhecimento do docente pesquisador das turmas, pois os educandos apresentavam bastante dificuldades quanto aos assuntos relacionados à Multiplicação com os Números Naturais nas tarefas presenciais e sem uso de ferramentas eletrônicas como suporte nos cálculos.

Esses resultados com os acertos dos educandos atribui-se a alguns fatores que podem ter ocorrido na resolução dos mesmos. Como as tarefas foram realizadas nas suas casas, eles podem ter utilizado calculadora ou outras ferramentas para 
solucionar as tarefas. Outro fato comum, nesses casos, é a participação e a colaboração dos responsáveis na sua execução. E por fim, espera-se que não seja nenhuma das atribuições anteriores ou seja, espera-se que os educandos tenham resolvido as tarefas, adquirido conhecimento e produzido significado. Acredita-se que houve um bom desenvolvimento quanto ao seu conhecimentos, pois nas questões 1 , 2 e 3 impressa, questões com mesmos conteúdos, ocorreu uma elevação nos acertos e na questão 8 verificou-se algumas produções de significados a partir do compartilhamento de interlocutores no grupo de WhatsApp, o qual o aluno Flávio demostrou sua produção de significados a partir da contribuição da aluna Ellen e na interação entre as alunas Vitória e Vanessa, que desenvolveram seus conhecimentos produzindo significado.

Após o término da análise dos materiais impressos não foi possível realizar a devolução desses materiais aos educandos devido a troca do ano letivo 2020 para 2021 e a transferência do pesquisador para outra unidade escolar. Foi encaminhado um agradecimento aos alunos e aos profissionais que apoiaram essa pesquisa para o diretor da escola. O agradecimento e retorno via Whatsapp também foi impossibilitado, pois os educandos saíram do grupo com término do ano letivo de 2020. 


\section{7 - CONSIDERAÇÕES FINAIS}

Iniciou-se a pesquisa com o objetivo de utilizar as TIC, com o software Hot Potatoes e a finalidade de auxiliar no problema do desinteresse dos educandos pelos conteúdos com a aplicação de tarefas de Multiplicação, após observação do raciocínio lógico presente nas avaliações externas e os baixos índices do município nessas avaliações.

No decorrer da pesquisa, a Pandemia do Covid-19 surpreendeu a todos, o que alterou todo o rumo do trabalho, pois a aplicação da sequência de tarefas seria presencial numa sala de aula e posteriormente trabalhadas num laboratório de informática para analisarmos a produção de significados. Mediante essa situação, adotou-se as ferramentas disponíveis para prosseguir com a pesquisa. Nesse caso, a nova estratégia adotada foi analisar tarefas realizadas de forma remota, ou seja, as tarefas foram enviadas juntamente com os materiais da escola, de forma impressa, e foram realizadas num período determinado com apoio e auxílio de um grupo criado no aplicativo WhatsApp que culminou o primeiro Produto Educacional dessa pesquisa.

O diálogo desenvolvido no grupo desse aplicativo foi um dos elementos objeto de análise da pesquisa para verificação se haveria produção de significados referente às tarefas estabelecidas e enviadas aos educandos, através de uma análise utilizando o Modelo dos Campos Semânticos. Juntamente com os diálogos, foram coletados também os resultados das atividades impressas devolvidas ao professor pesquisador.

Em relação à sequência de tarefas envolvendo os conteúdos de Multiplicação de números naturais com o raciocínio lógico, objetivou-se analisar a produção de significados dos educandos tanto nos materiais impressos como nas discussões do grupo de WhatsApp.

Quanto à aplicação remota, ou seja, o envio das atividades impressas aos educandos, é importante ressaltar que foram enviados aos 56 educandos participantes da pesquisa e apenas 26 devolveram os materiais. Apesar desses números e da "não presencialidade", os resultados das análises dos materiais foram satisfatórios, pois foi possível, através da escrita, conforme o MCS, identificar as produções de significados dos educandos.

Já em relação a utilização do aplicativo WhatsApp, primeiro é necessário destacar que embora 56 educandos tenham sido convidados a participar da pesquisa, 
apenas 36 puderam colaborar. O motivo se deu pela dificuldade destes terem acesso à internet ou celular. Nota-se, com essa realidade, que há muitas dificuldades de acesso dos educandos, principalmente da zona rural a equipamentos de informática e internet para uso em seus estudos, ficando estes dependentes quase que exclusivamente dos laboratórios de informática existentes nas escolas.

Quanto aos educandos que conseguiram acesso, foi observado que os educandos interagiram no grupo criado para esse fim, tiraram dúvidas, observaram seus equívocos e ampliaram seus conhecimentos com estratégias utilizadas por outros colegas. Foi possível notar as dificuldades que determinados educandos enfrentaram em entender a explicação de alguns colegas e também a cooperação e colaboração entre eles.

Nesse sentido, percebe-se que os docentes podem e devem utilizar o WhatsApp como estratégia educacional, pois podem despertar interações e colaboração que, às vezes, não ocorrem na sala de aula, por causa da timidez ou insegurança. Além desses fatos, mediante o cenário educacional diante à Pandemia, esse recurso pode colaborar muito no processo de ensino e aprendizagem dos educandos a partir dos estudos online ou de forma remota.

Ao analisar o desenvolvimento das postagens no grupo de WhatsApp e o desenvolvimento das tarefas impressas enviadas de forma remota, utilizando o Modelo dos Campos Semânticos, também observou-se produções de significados.

Nos materiais impressos, a parir do MCS, verificou-se o desencadeamento de alguns processos para solucionar um determinado problema com utilização de operação (multiplicação e adição) em que os educandos compartilharam interlocutores e assim apresentando a produção de significados, conforme ocorreu nas três primeiras questões em que o quantitativo de acertos foram crescendo de acordo com a prática nas questões. Dessa forma, com a prática, desenvolveram seu raciocínio lógico, que é executar os cálculos com agilidade e coerência para chegar aos resultados da questão. Outro fato observado é que as diferentes formas de solução das tarefas, demonstraram que os educandos podem produzir significados de formas distintas.

Quanto ao uso do WhatsApp, foi notória a produção de significados nas interações entre os educandos Ellen e Flávio e entre as alunas Vitória e Vanessa que compartilharam conhecimento e apresentaram seus resultados e sua produção de significados, pois os educandos Flávio e Vanessa solicitaram ajuda no grupo de 
WhatsApp mediante as dificuldades para resolver a questão 8 e as alunas Ellen e Vitória, respectivamente, compartilharam interlocutores e contribuíram para o desenvolvimento e a produção de significados dos colegas.

Com isso, responde-se o questionamento inicial: como a aplicação de tarefas envolvendo multiplicação no Conjunto dos Números Naturais com o uso das TIC podem estimular o desenvolvimento do Raciocínio Lógico Matemático em educandos do Ensino Fundamental? A tecnologia do WhatsApp instigou o desenvolvimento do raciocínio lógico dos educandos e contribuiu com o compartilhamento de estratégias apresentadas no grupo para que eles desenvolvessem suas resoluções a partir de diferentes formas e obtivessem os resultados gerando, assim, suas produções de significados e suas justificações conforme ilustrações supracitadas. Espera-se que a demonstração dos resultados dessa pesquisa estimule docentes na adesão da utilização dessa ferramenta e de outras no processo de ensino e aprendizagem de educandos.

Como a proposta inicial seria utilizar tarefas envolvendo o software Hot Potatoes na aplicação de nossa pesquisa e isso não foi possível devido à Pandemia, elaborou-se como segundo Produto Educacional, um recurso educacional digital no formato de um quizz, utilizando o software para que os docentes possam usufruir em suas futuras aulas. Tal iniciativa possibilitará mais uma estratégia com o uso de recursos tecnológicos a fim de estimular e incentivar o ensino e aprendizagem dos educandos. 


\section{REFERÊNCIAS BIBLIOGRÁFICA}

AZEVEDO, G. T. D. A construção do pensamento matemático aliada a linguagem computacional gráfica scratch: desafios, possibilidades e contradições. In: XIX EBRAPEM - ENCONTRO BRASILEIRO DE ESTUDANTES DE PÓS-GRADUAÇÃO EM MATEMÁTICA, 2015, Juiz de Fora, MG. Anais... Juiz de Fora, MG: UFJF, 2015.

BAIRRAL, M. A. Pesquisa, ensino e inovação com tecnologias em educação matemática: de calculadoras e ambientes virtuais, $1^{\text {a }}$ ed. Seropédica, RJ: ED. da UFRRJ, 2012.

BARBOSA, D. N. F. et al. Ensinando lógica com as tecnologias da informação: desenvolvendo o raciocínio e o pensamento computacional. Revista de Extensão da Universidade de Cruz Alta, v. 9, p. 19, nov 2017. Disponivel em: $<$ http://revistaeletronica.unicruz.edu.br/index.php/Cataventos/article/view/5334/1127 >. Acesso em: 03 ago 2018.

BATISTA, E. J. S. et al. Utilizando o Scretch como ferramenta de apoio para desenvolver o raciocínio lógico das crianças do ensino básico de uma forma multidisciplinar. Anais do XXI Workshop de Informática na Escola, Mato Grosso do Sul, 2015. 10.

BRASIL. Secretaria de Educação Fundamental. Parâmetros curriculares nacionais: matemática. Brasília: MEC/SEF, 1997. 35 p.

Ministério da Educação. Base Nacional Comum Curricular. Brasília: MEC, Consed, Undime, 2018. 11p.

BOGDAN, C.; BIKLEN,. Investigação qualitativa em Educação: uma introdução à teoria e aos métodos. Portugal: Editora Porto, 1994.

COELHO, P. M. F. Os nativos digitais e as novas competências tecnológicas. Texto Livre - Linguagem e Tecnologia, Minas Gerais, 2012. $8 \mathrm{f}$.

DIAS, R. F. Gestão escolar e novas tecnologias digitais: : inserção e desafios às práticas pedagógicas. Universidade de Brasília, Brasília, 2014. $45 \mathrm{f}$.

FERNANDO, P. H. L. et al. A ferramenta tecnologica para o desenvolvimento do raciocinio lógico da matemática no ensino fundamental. In: Simpósio Internacional de Educação a Distância - SIED, São Paulo, 8-27 set 2016.

FOLETTO, S. C. O raciocínio Lógico Entendido como Disciplina no Estado do Mato Grosso do Sul. 2016. 19. Universidade Federal da Integração LatinoAmericana, Foz do Iguaçu, 2016.

FONSECA, E. A. A. D. Metodologia para auxiliar professores de matemática. 2014. 118 f. Dissertação de Mestrado Profissional em Educação Matemática, Universidade Federal de Juiz de Fora, Juiz de Fora, 2014.

HEGENBERG, L. Lógica: calculo Sentencial. 2 ed. São Paulo: EPU, 1977

HERMINIO, M. H. G. A.; BORBA, M. D. C. A noção de interesse em projetos de modelagem matemática. 2010. 12 f. Pesquisa em Educação Matemática (online), São Paulo, 12.

JÚNIOR, W. M. P.; NETO, J. R. F.; COSTA, M. O. Utilização do Software Hot Potatoes para a Produção de Jogos Educacionais. 2002, 10 f. Simpósio Brasileiro de Informática na Educação - SBIE. 
KENSKI, V. M. Educação e tecnologia: o novo ritmo da informação. $2^{a}$ edição. Campinas - SP: Papirus, 2007.

KENSKI, V. M. Educação e Tecnologia: o novo ritmo da informação. $8^{a}$. ed. Campinas: Papirus, 2012.

KOLOGESKI, A. L. et al. Desenvolvendo o raciocínio lógico e o pensamento computacional: experiências no contexto do projeto logicando. Novas Tecnologias na Educação - CINTED - UFRGS, Rio Grande do Sul, dez 2016. 10.

LISBOA. I. P; MALAFAIA. L. G. F. O uso do software hot potatoes no ensinoaprendizagem da gramática. Universidade Federal Rural da Amazônia. 2014.

MACHADO, N. J.; CUNHA, M. O. D. A lógica, a língua e a matemática. Lógica e a linguagem cotidiana. Autêntica, Belo Horizonte, 2015.

MACHADO, N. J. Lógica? É Lógico! São Paulo: Scipione, 2000

MARQUES, G.M. Implicação dos pilares do pensamento computacional na resolução de problemas na escola. UNISC. Universidade de Santa Cruz do Sul. 2019

NAHRA, C.; WEBER, I. H. Através da Lógica. Petrópolis: Vozes, 1997

NETO. B.C.S. Produção de significados matemáticos e história da matemática: uma proposta de tarefas didáticas sobre o Teorema de Tales. Instituto Federal de Educação, Ciência Tecnologia de Goiás. EBRAPEM. 2015

PAULA, M. R. D.; SILVA, M. D. Razão como taxa: Uma proposta de ensino para a sala de aula de matemática. 2012. 30 f. Dissertação de Mestrado Profissional em Educação Matemática, Universidade Federal de Juiz de Fora, 2012, Juiz de Fora, MG.

PRIETO, L. M. et al. Uso das tecnologias digitais em atividades didáticas nas séries iniciais. Novas Tecnologias na Educação - CINTED - UFRGS, Rio Grande do Sul, mai 2005. $11 \mathrm{f}$.

PRIETO, M. J. Fundamental, Raciocínio Lógico Matemático para o Ensino. Científica Multidisciplinar Núcleo do Conhecimento, v. 5, n. 4, p. 54-76, abr 2018. Disponivel em: $\quad<$ https://www.nucleodoconhecimento.com.br/matematica/raciocinio-logicomatematico>. Acesso em 11 nov 2018.

ROSSO, A. Z.; FLORES, M. L. P. Mídias na Educação a pedagogia e a tecnologia subacentes: A utilização de software educativo na educação de menores infratores. 2017, p.197, UNIPAMPA, UFRGS.

SCOLARI, A. T.; CORDENONSI, A. Z. O desenvolvimento do Raciocínio lógico através de objetos de aprendizagem. Revista Renote - Novas Tecnologias na Educação, Rio Grande do Sul, 2007.

SILVA, M. D. Sobre a dinâmica da produção de significados para a matemática. 2003. 244 f. Tese de Dotourado em Educação Matemática - UNESP, São Paulo 2003.

SILVA, M. D.; LINS, C. Sobre a dinâmica da produção de significados para a matemática. 2003. 30 f. In:Jornal Internacional de Estudos em Educação Matemática - JIEEM, 2003.

SILVA, M. S. Elaboração de atividades com tecnologias digitais: algumas considerações. In: XXI ERAPEM - ENCONTRO BRASILEIRO DE ESTUDANTES DE 
PÓS-GRADUAÇÃO EM MATEMÁTICA, 2017, Rio Grande do Sul, Anais... Rio Grande do Sul: Universidade Federal de Pelotas, 2017.

SILVEIRA, S. R.; RANGEL, A. C. ; CIRÍACO, E. D. L. Utilização de jogos digitais para o desenvolvimento do raciocínio lógico-matemático. Revista de Educação, Ciência e Tecnologia. Canoas, v. 1, n. 1, p. 14, 2012. Acesso em: 12 jan 2019.SOUZA, D.O. Ensino de Matemática com o Uso das TIC. LUME, Repositório Digital, UFRGS. 2015. Disponível em: www.somatematica.com.br/softwares.php\#topolista. Acesso em: 10 jan 2020. 